\title{
Acidic deposition effects on above- and belowground wood biomass and nutrient status in a young hardwood forest
}

Brittany Anne Johnson

West Virginia University

Follow this and additional works at: https://researchrepository.wvu.edu/etd

\section{Recommended Citation}

Johnson, Brittany Anne, "Acidic deposition effects on above- and belowground wood biomass and nutrient status in a young hardwood forest" (2009). Graduate Theses, Dissertations, and Problem Reports. 4480.

https://researchrepository.wvu.edu/etd/4480

This Thesis is protected by copyright and/or related rights. It has been brought to you by the The Research Repository @WVU with permission from the rights-holder(s). You are free to use this Thesis in any way that is permitted by the copyright and related rights legislation that applies to your use. For other uses you must obtain permission from the rights-holder(s) directly, unless additional rights are indicated by a Creative Commons license in the record and/ or on the work itself. This Thesis has been accepted for inclusion in WVU Graduate Theses, Dissertations, and Problem Reports collection by an authorized administrator of The Research Repository @ WVU. For more information, please contact researchrepository@mail.wvu.edu. 
Acidic deposition effects on above- and belowground wood biomass and nutrient status in a young hardwood forest

Brittany Anne Johnson

Thesis submitted to the Davis College of Agriculture, Natural Resources and Design

at West Virginia University in partial fulfillment of the requirements

for the degree of

\author{
Master of Science \\ in \\ Forestry
}

Kathryn B. Piatek, Ph.D., Chair

John R. Brooks, Ph.D.

Mary Beth Adams, Ph.D.

Division of Forestry and Natural Resources

Morgantown, West Virginia

2009

Keywords: Fernow Experimental Forest, acidic deposition, dolomitic lime, aboveground wood biomass, productivity, SILVAH, fine roots 


\section{Abstract \\ Acidic deposition effects on above- and belowground wood biomass and nutrient status in a young hardwood forest}

\section{Brittany Anne Johnson}

The impact of acid deposition on forest productivity has been studied extensively during the past 30 years. Mixed results abound due to variations in forest age, species composition, land use history, climate, and different experimental procedures. However, most results suggest alterations in productivity and nutrient status as a result of elevated acid deposition. The Long-Term Soil Productivity (LTSP) site in the Fernow Experimental Forest served as the study site; it was initiated with the purpose of observing the impact of forest management and air quality on biomass production and nutrient cycling (Adams et al. 2004). In its entirety, this experiment specifically examines the effect of acidification on above- and belowground wood productivity as well as the nutrient relations within those pools. Three treatments were replicated in four blocks, in which all naturally regenerated after whole-tree harvesting in 1996. The treatments included a control (WT), ammonium sulfate additions at two times the annual ambient rate (WT+NS), and ammonium sulfate additions (two times ambient) plus dolomitic lime additions that was added at two times the rate of calcium and magnesium export to local stream waters $(\mathrm{WT}+\mathrm{NS}+\mathrm{CA})$. The liming treatment was implemented to test ameliorative effects on acidified soil conditions. The first study estimated forest productivity, expressed as total aboveground wood biomass and included stem and branch weight of standing live trees, among the three treatments ten years after stand regeneration and treatment initiation. Total aboveground wood biomass was compared among three treatments. Additionally, future stand productivity was estimated for a subsequent 70 years using growth projection simulator SILVAH. Total aboveground wood biomass at ten years was not significantly different among treatments (ANOVA: $F=1.20, p=0.33$, $\mathrm{n}=9$ ). Projected aboveground wood biomass estimated the WT+NS+CA treatment may increase 34 percent by forest age 80 . The second study involved macro- and micronutrient analysis of stem wood tissue from each treatment in five of the most abundant species. These species included yellow-poplar, red maple, sweet birch, black cherry, and pin cherry; northern red oak was also examined. Results suggest altered (though not significantly so) wood concentrations of $\mathrm{K}, \mathrm{Ca}$, and $\mathrm{Zn}$ in the WT treatment compared to the WT+NS and WT+NS+CA treatments. The data also indicated possible signs of nutrient stress in the WT+NS treatment due to lower wood Ca:Mn and higher $\mathrm{N}: \mathrm{P}$ nutrient ratios compared to the WT and WT+NS+CA treatment. The third study was carried out to understand the effects of simulated acidic deposition and additions of dolomitic lime on belowground fine root $(\leq 2 \mathrm{~mm})$ biomass and nutrient levels. Differences in fine root biomass and nutrient content were observed in these plots due to significant block*treatment interactions (ANOVA: $\mathrm{F}=5.27, \mathrm{p}<0.05, \mathrm{n}=9$ ). Compared to the WT+NS treatment in block III, fine root nitrogen and phosphorus content was significantly lower in the WT and WT+NS treatments in block II and the WT and $\mathrm{WT}+\mathrm{NS}+\mathrm{CA}$ treatments in block IV. 


\section{Acknowledgement}

I am grateful for every person who offered their help to me while working on this research in addition to the USDA McIntire-Stennis Program, who provided funding for this project. I was honored to work with each of my advisors, Dr. Kate Piatek, Dr. John Brooks, and Dr. Mary Beth Adams, as they provided me with invaluable knowledge of researching, writing, and concepts in forest ecology, soils, and biometrics. Bill Peterjohn, Phil Turk, Pete Knopp, and two anonymous reviewers offered valuable insights prior to manuscript submission to the Conference Proceedings of Ecology and Management of High-Elevation Forests of the Central and Southern Appalachian Mountains. I would also like to thank the Fernow logging crew, Amanda Lynch, Sheni Johnson, Doug Owens, Paul Ludrosky, Bibu George, Elizabeth Tichner, Daniel Farcas, Adi Adumitroaie, Nathan Beane, Brian McDonald, and Kristen Magnuson provided enthusiastic and essential help in the lab and field. Lastly, I am extremely thankful for my encouraging and supportive friends and family who were behind me in every step while completing my thesis. 


\section{Table of Contents}

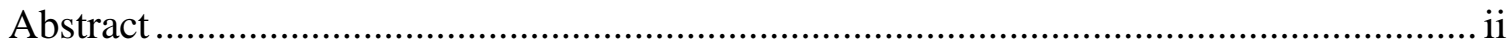

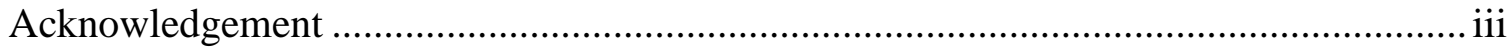

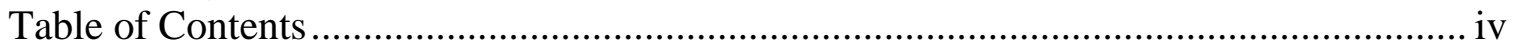

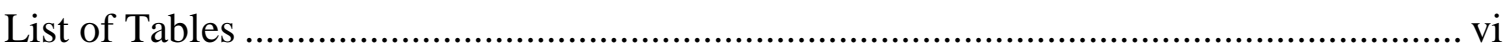

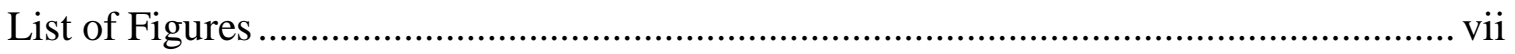

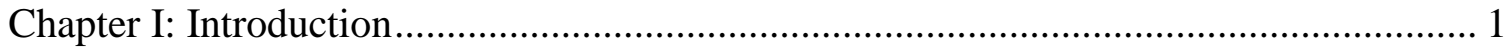

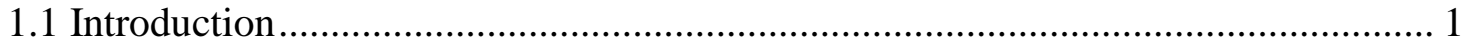

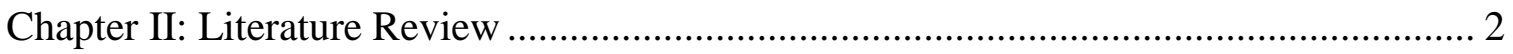

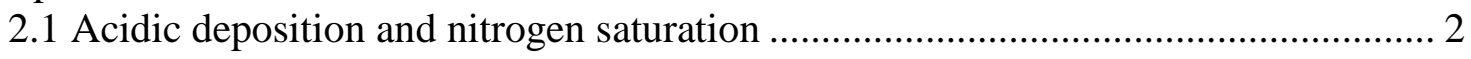

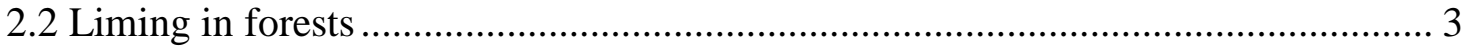

2.3 Aboveground wood biomass and nutrient concentrations ................................. 5

2.4 Belowground biomass and nutrient concentrations ............................................ 8

2.5 Objectives of this study.............................................................................. 10

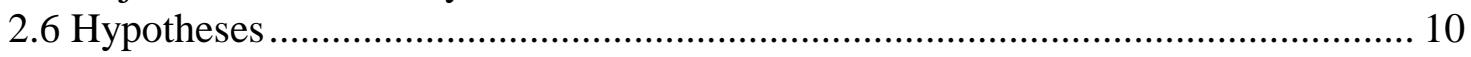

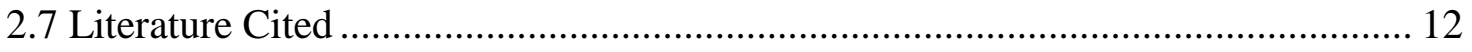

Chapter III: Does nitrogen and sulfur deposition affect forest productivity? .................. 20

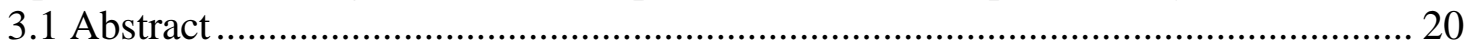

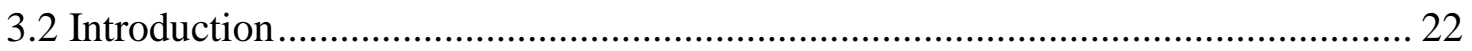

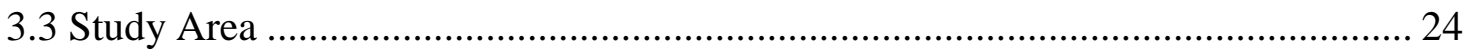

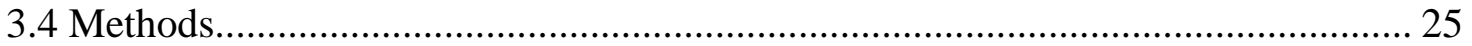

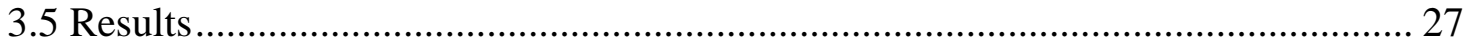

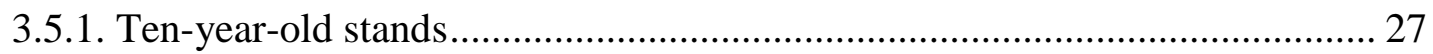

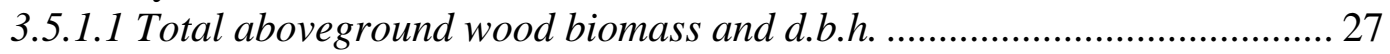

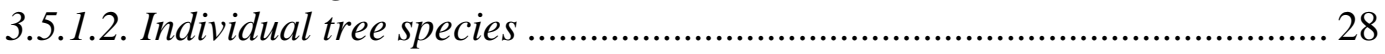

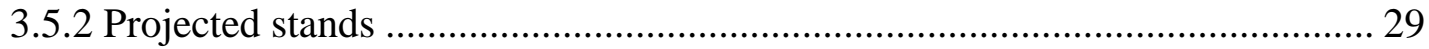

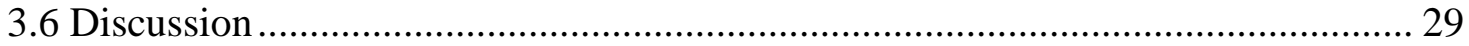

3.6.1 Total aboveground wood biomass production of ten-year-old stands ............ 29

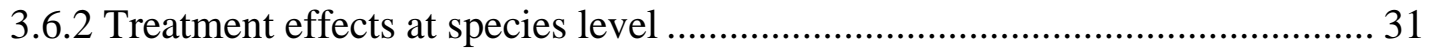

3.6.3 Potential future stand productivity ............................................................. 32

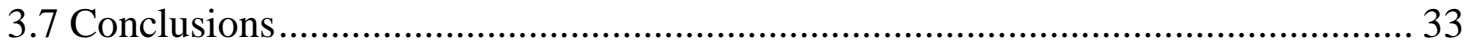

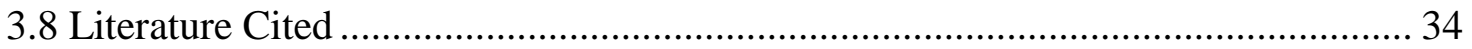

Chapter IV: The effects of nitrogen, sulfur, and lime additions on stem wood nutrition in

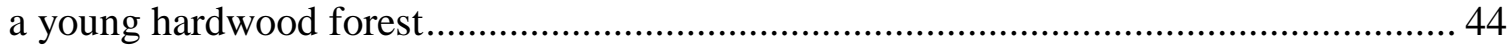

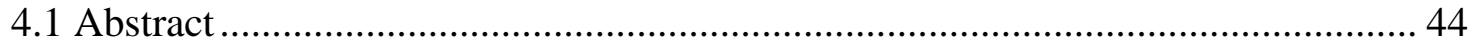

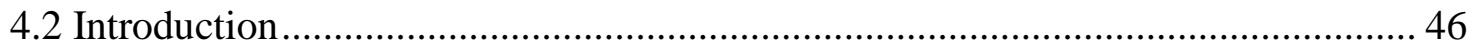

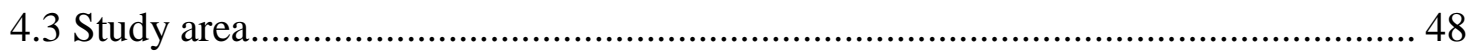

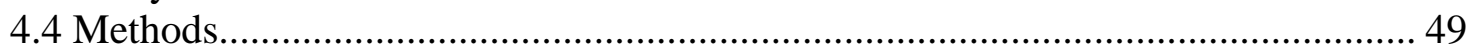

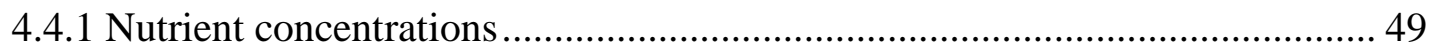

4.4.2 Aboveground wood biomass and nutrient content....................................... 50

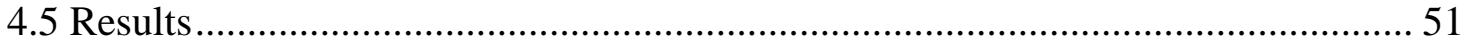

4.5.1 Treatment differences in wood nutrient concentrations................................. 51

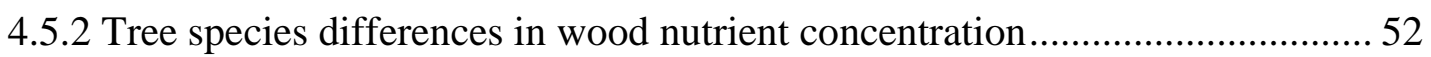

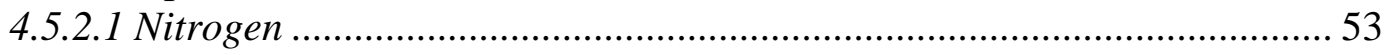

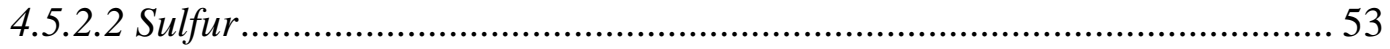




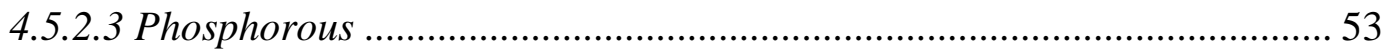

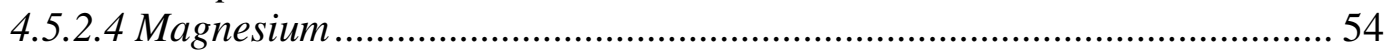

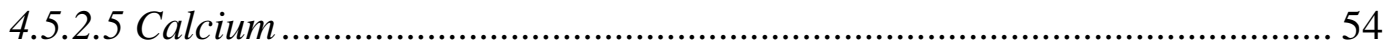

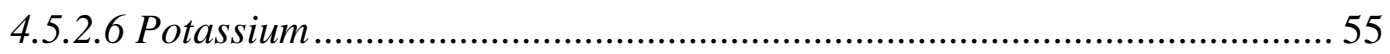

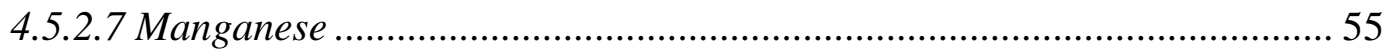

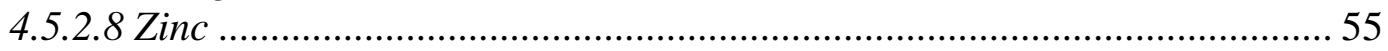

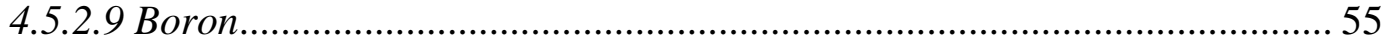

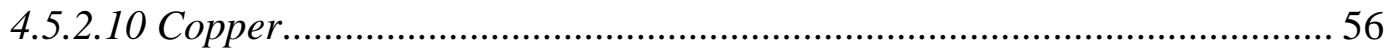

4.5.3 Total aboveground wood nutrient content ……………................................ 56

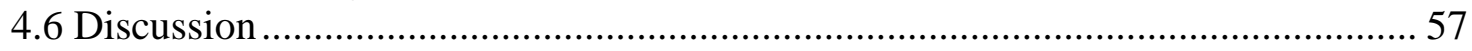

4.6.1 Treatment effects on wood nutrient concentrations and contents.................... 57

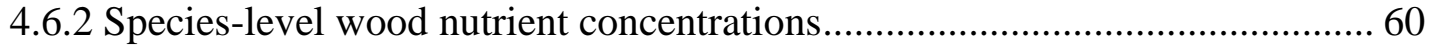

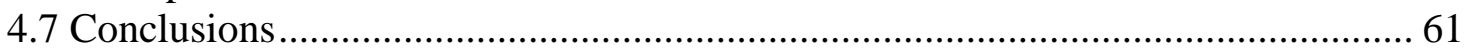

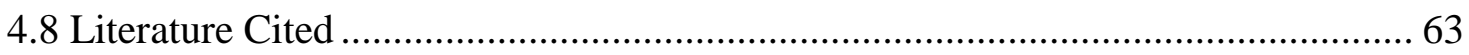

Chapter V: Are fine roots affected by ammonium sulfate and dolomitic lime amendments

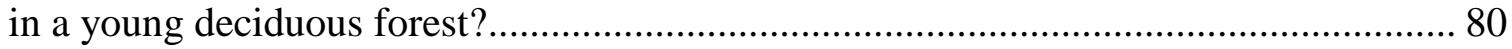

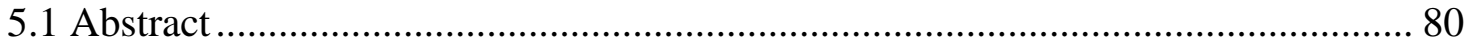

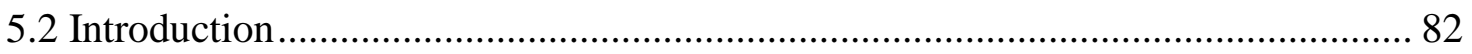

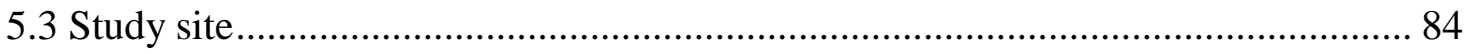

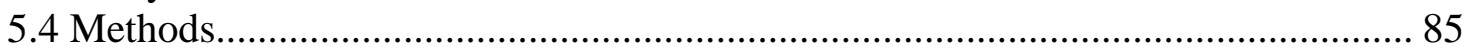

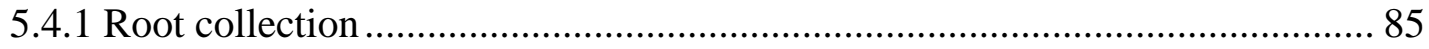

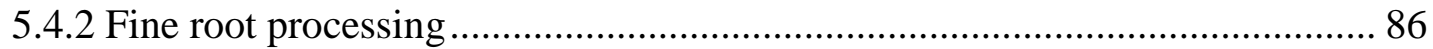

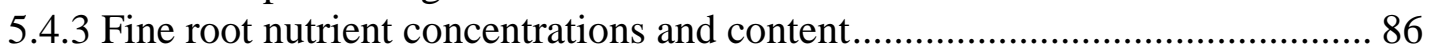

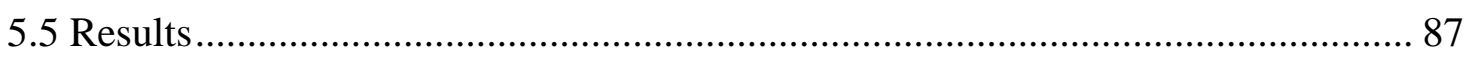

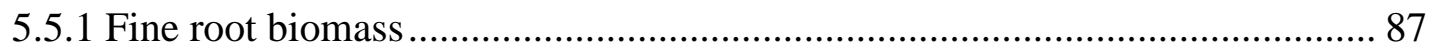

5.5.2 Fine root nutrient concentrations ............................................................... 88

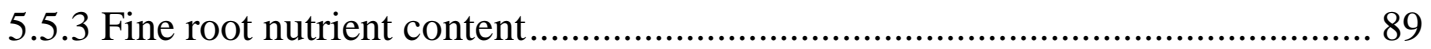

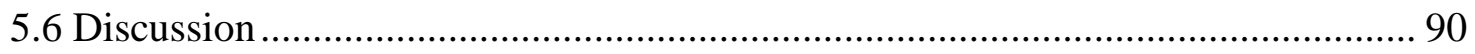

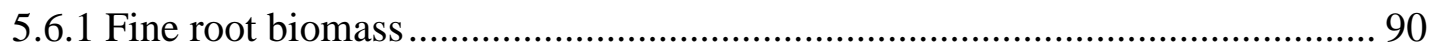

5.6.2 Are above- and belowground biomass productivity related? ......................... 91

5.6.3 Fine root nutrient concentrations and content................................................ 92

5.6.4 Block differences in fine root biomass and nutrient content .......................... 93

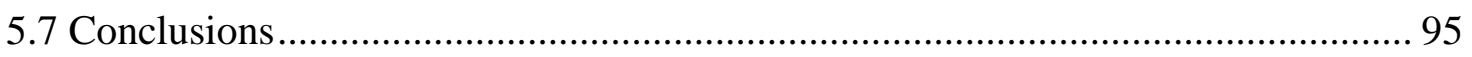

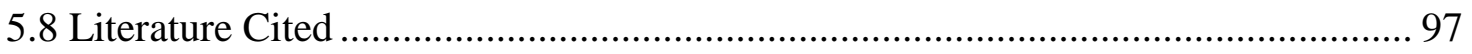

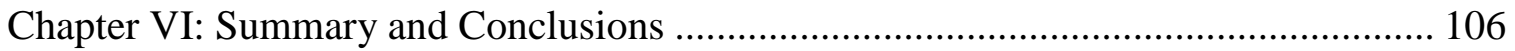

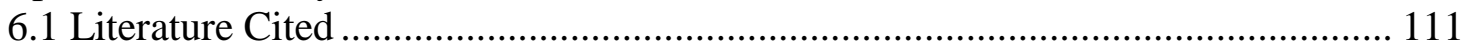

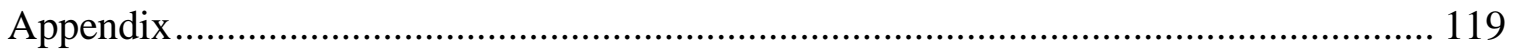




\section{List of Tables}

Table 1. Individual tree species dry weight equations based on d.b.h. $\left(Y=a x^{b}\right)$, where $y=$ total aboveground tree dry weight, $\mathrm{x}=$ tree d.b.h., $\mathrm{a}$ and $\mathrm{b}=$ regression constants......... 41 Table 2. Trees per hectare (TPH) used to calculate percent relative density (RD) for the dominant tree species $\geq 2.54 \mathrm{~cm}$ d.b.h. by treatment.

Table 3. P-values associated with the effects of block, treatment (trt), and species (spp) on macronutrient concentration (\%) and content $\left(\mathrm{kg} \mathrm{ha}^{-1}\right)$ in aboveground woody biomass at the LTSP site. N/A denotes data not available.

Table 4. P-values associated with the effects of block, treatment (trt), and species (spp) on micronutrient concentration $(\mathrm{ppm})$ and content $\left(\mathrm{kg} \mathrm{ha}^{-1}\right)$ in aboveground woody biomass at the LTSP site. N/A denotes data not available.

Table 5. Nutrient concentrations by tree species and treatment; $p$-values associated with treatment are in Table 1.

Table 6. Total aboveground wood biomass in $\mathrm{kg} \mathrm{ha}^{-1}$ and content for macro- and micronutrients $\left(\mathrm{kg} \mathrm{ha}^{-1}\right)$ by treatment, with associated p-values. Carbon content is $50 \%$ of total biomass.

Table 7. Aboveground wood biomass $\left(\mathrm{kg} \mathrm{ha}^{-1}\right)$ according to the most abundant species and their totals for each treatment, with associated p-values. Significant differences are indicated by different letters in the same row.

Table 8. P-values for block, treatment, and block* treatment interactions for fine root biomass $\left(\mathrm{kg} \mathrm{ha}^{-1}\right)$, and fine root nutrient concentrations $(\%)$ and nutrient contents $\left(\mathrm{kg} \mathrm{ha}^{-}\right.$

$\left.{ }^{1}\right)$. N/A denotes data not available.

Table 9. Fine root macronutrient content values by treatment and block. Significant differences are indicated by different letters in the same column. All values are reported in $\mathrm{kg} \mathrm{ha}^{-1}$. 105

Table 10. List of common and scientific names of the tree species present on the Fernow

Long-Term Soil Productivity site. 


\section{List of Figures}

Figure 1. Total aboveground wood biomass values by treatment for the ten-year-old

Long-Term Soil Productivity site.. ……………………………………………....... 42

Figure 2. Comparison between treatments of the dominant species' wood biomass component on the Fernow Long-Term Soil Productivity site. .......................................... 42

Figure 3. Projected growth in aboveground wood biomass over 80 years by treatment. . 43

Figure 4. Average wood nutrient concentrations by treatment.......................................... 77

Figure 5. Average wood nutrient concentrations by treatment...................................... 77

Figure 6. Wood tissue calcium to manganese concentration ratios by treatment............. 78

Figure 7. Tree species phosphorous wood concentrations as a comparison between treated

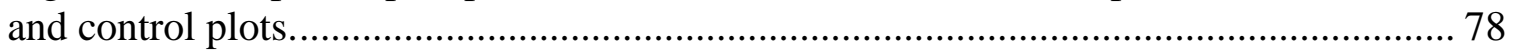

Figure 8. Tree species magnesium wood concentrations as a comparison between treated

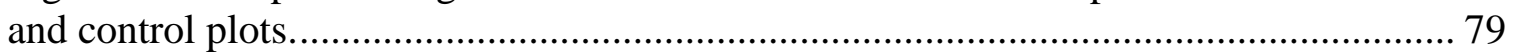

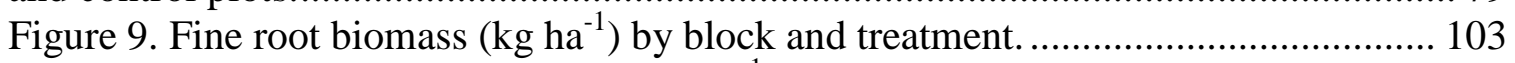

Figure 10. Fine root nitrogen content $\left(\mathrm{kg} \mathrm{ha}^{-1}\right)$ by block and treatment....................... 103

Figure 11. Fine root phosphorus content $\left(\mathrm{kg} \mathrm{h}^{-1}\right)$ by block and treatment.................... 104

Figure 12. Fine root calcium content $\left(\mathrm{kg} \mathrm{ha}^{-1}\right)$ by block and treatment............................. 104

Figure 13. Foliage, aboveground wood, and fine root biomass $\left(\mathrm{kg} \mathrm{ha}^{-1}\right)$ in a ten-year-old

forest at the Fernow Experimental Forest.................................................................... 112

Figure 14. Foliage, aboveground wood, and fine root carbon content $\left(\mathrm{kg} \mathrm{ha}^{-1}\right)$ in a ten-

year-old forest at the Fernow Experimental Forest. Standard deviations are in parentheses

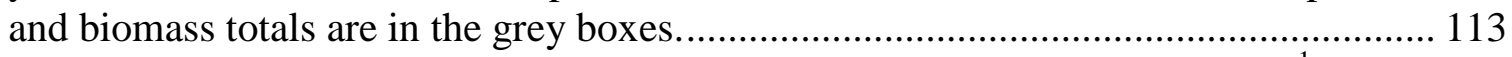

Figure 15. Foliage, aboveground wood, and fine root nitrogen content $\left(\mathrm{kg} \mathrm{ha}^{-1}\right)$ in a tenyear-old forest at the Fernow Experimental Forest........................................................ 114 Figure 16. Foliage, aboveground wood, and fine root phosphorus content $\left(\mathrm{kg} \mathrm{ha}^{-1}\right)$ in a ten-year-old forest at the Fernow Experimental Forest. ................................................ 115 Figure 17. Foliage, aboveground wood, and fine root potassium content $\left(\mathrm{kg} \mathrm{ha}^{-1}\right)$ in a tenyear-old forest at the Fernow Experimental Forest..................................................... 116 Figure 18. Foliage, aboveground wood, and fine root calcium content $\left(\mathrm{kg} \mathrm{ha}^{-1}\right)$ in a tenyear-old forest at the Fernow Experimental Forest......................................................... 117 Figure 19. Foliage, aboveground wood, and fine root magnesium content $\left(\mathrm{kg} \mathrm{ha}^{-1}\right)$ in a ten-year-old forest at the Fernow Experimental Forest. 


\section{Chapter I: Introduction}

\subsection{Introduction}

Global production from food, energy, and industry was ten times greater in the 1990's compared to production in 1860 and this trend in increased production has continued into the $21^{\text {st }}$ century due to growing human populations (Galloway et al. 2004). Consequently, anthropogenic activities have caused a rise in atmospheric nitrogen $(\mathrm{N})$ deposition. The northeastern region of the United States experiences the highest rates of $\mathrm{N}$ and sulfur (S) deposition according to the National Atmospheric Deposition Program (NADP, 2008). Because of increased ecosystem loading, cycling of $\mathrm{N}$ through air, land, and water, is altered and the consequences of greater $\mathrm{N}$ deposition can have important implications on ecosystem function; most notably, the occurrence of $\mathrm{N}$ saturation. Nitrogen saturation has been defined as the inputs of $\mathrm{N}$ exceeding the biological demand of an ecosystem (Aber et al. 1989). Saturation can lead to loss of nitrate to stream waters, altered species composition, decreased soil C:N ratio, decreased foliar biomass, increased cation leaching losses, lower fine root biomass, and an eventual decrease in net primary productivity (Aber et al. 1989). An altered $\mathrm{N}$ cycle also affects the cycling of base cations such as calcium $(\mathrm{Ca})$, magnesium $(\mathrm{Mg})$, and potassium $(\mathrm{K})$ as well as the anions sulfur (S) and phosphorous (P) (Johnson 1992). Depletion of these other necessary nutrients may impact the productivity and health of a forest community (Adams et al. 2000, Yanai et al. 1999, Hamburg et al. 2003, Sullivan et al. 2006, Bigelow and Canham 2007). 


\section{Chapter II: Literature Review}

\subsection{Acidic deposition and nitrogen saturation}

The importance of understanding the effects of acid deposition, therefore potential $\mathrm{N}$ saturation, on forests that vary in age, species composition, site fertility, and land-use history, has resulted in the initiation of numerous experiments in Europe and the United States over the past 20 years. These studies include the G2 NITREX sites in Sweden, Bear Brook Watershed in Maine, Hubbard Brook in New Hampshire, Harvard Forest in Massachusetts, and the Fernow Watershed Acidification Study in West Virginia. The results from the studies performed at these sites have increased the understanding of acidic deposition in forest ecosystems.

Fertilization experiments that apply ammonium sulfate or ammonium nitrate allow for more rapid realizations into how forests may be impacted by acidic deposition; for instance, accelerated cation leaching (Adams et al. 2004). The input of acidic ions $\left(\mathrm{NO}_{3}{ }^{-}\right.$

and $\left.\mathrm{SO}_{4}{ }^{2-}\right)$ and hydrogen $(\mathrm{H}+)$ into forest soils can increase the rate of rock and soil weathering, which can eventually lead to the replacement of $\mathrm{Ca}^{2+}$ and $\mathrm{Mg}^{2+}$ by $\mathrm{Al}^{3+}$ on soil exchange sites (DeWalle et al. 2006). Mobility and leaching of cations over time can increase the acidity of forest soils and receiving stream waters. Consequently, vegetative productivity and stream water health can be negatively affected by chronic acidic deposition. The $\mathrm{N}$ saturation hypothesis (inputs of $\mathrm{N}$ exceed biological $\mathrm{N}$ demand of ecosystem) proposed by Aber et al. (1989) suggests numerous changes in a forest 
ecosystem, in terms of $\mathrm{N}$ cycling and plant response, that receives excessive $\mathrm{N}$ deposition. Forests in the Appalachian region may be especially susceptible to $\mathrm{N}$ saturation as most soils are derived from sandstone and shale, which have lower concentrations of $\mathrm{Ca}^{2+}, \mathrm{Mg}^{2+}$, and $\mathrm{HCO}^{3-}$, and thereby a lower soil $\mathrm{pH}$ and buffering capacity to acidification (DeWalle et al. 2006). The paired-watershed fertilization experiments at the FEF and Bear Brook Watershed in Maine have demonstrated treatment-induced depletion of base cations in soil water (Fernandez et al. 2003, Edwards et al. 2006).

\subsection{Liming in forests}

Liming may alleviate symptoms of acidification (Andersson et al. 1999, Valeur et al. 2000, Moore and Ouimet 2006). Studies from Sweden have shown three to four times greater dissolved organic carbon leaching in limed $\mathrm{O}+\mathrm{A}$ and $\mathrm{O}+\mathrm{A}+\mathrm{B}$ horizons compared to the control (Andersson et al. 1999) and decreased net sulfur mineralization with increasing lime application rates (Valeur et al. 2002). Sugar maple stands in Canada that received ten years of dolomitic lime resulted in reduced crown dieback, increased $\mathrm{Ca}$ and $\mathrm{Mg}$ foliar concentrations, and a basal area increment that was double that of unlimed trees (Moore and Ouimet 2006). Forest liming has also been utilized in declining sugar maple stands in the northeastern U.S. to address deficiencies in soil Ca, which may be attributed to acidic soil conditions (Long et al. 1997, Wargo et al. 2002). Sugar maple decline has occurred in Pennsylvania since the mid-1980's and the application of lime in these stands has resulted in increased diameter growth and crown vigor of sugar maples; 
liming also increased levels of $\mathrm{Ca}$ and $\mathrm{Mg}$ and reduced $\mathrm{K}, \mathrm{Al}$, and $\mathrm{Mn}$ concentrations in the upper $15 \mathrm{~cm}$ of the soil (Long et al. 1997). Similar results were seen in a Vermont sugar maple stand that received base cation and/or lime fertilization; increased soil pH, foliar $\mathrm{Ca}$, and $\mathrm{P}$ concentrations, reduced crown dieback, and $200 \%$ greater diameter growth were observed in either lime or base cation fertilized plots (Wilmot et al. 1996). An increase in soil $\mathrm{pH}$ has resulted in numerous liming experiments, including the LTSP site in the FEF (Wallenstein et al. 2006). A LTSP treatment that included ammonium sulfate plus dolomitic lime additions saw significantly greater $\mathrm{pH}$ compared to the control and ammonium sulfate amended treatments, however there were no differences in soil $\% \mathrm{~N}, \% \mathrm{C}$, or net $\mathrm{N}$ mineralization and nitrification between all treatments. Another experiment (Piatek et al. 2009) demonstrated that ten years of treatment additions (WT+NS) lowered the capacity of litter for $\mathrm{N}$ immobilization and that dolomitic lime reversed the effect. Lastly, wollastonite $\left(\mathrm{CaSiO}_{3}\right)$ additions at Hubbard Brook (Groffman et al. 2006) resulted in an increase in soil $\mathrm{pH}$, but no response in stream, soil solution, and foliar concentrations of $\mathrm{N}$; declines were observed in microbial biomass $\mathrm{N}$ content, net $\mathrm{N}$ mineralization, and soil inorganic $\mathrm{N}$ pools in the $\mathrm{O}_{\text {ie }}$ horizon following $\mathrm{Ca}$ amendments. This study suggests that microbial activity may have been limited by other factors, such as phosphorous availability to microbes in this northeastern forest, as opposed to a rise in soil $\mathrm{pH}$ and $\mathrm{Ca}$. A forest's biogeochemical response to lime additions will undoubtedly vary due to differences in site characteristics; therefore a landowner must ensure the benefits outweigh the cost and feasibility of a liming treatment on acidic soils. 


\subsection{Aboveground wood biomass and nutrient concentrations}

An increase in $\mathrm{N}$ deposition has been shown to relieve $\mathrm{N}$ limitations in forests, as evidenced by increases in woody biomass; experiments have also shown a decline in tree productivity due to $\mathrm{N}$ additions. A $\mathrm{N}$ enrichment experiment in Massachusetts at the Harvard Forest (Aber et al. 1993, Magill et al. 1996, Magill et al. 1997, Magill et al. 2004) and an N deposition gradient experiment (Boggs et al. 2005) have demonstrated increases in wood biomass growth in hardwood forest stands, which suggests $\mathrm{N}$ limitation of this stand prior to $\mathrm{N}$ additions. The most recent assessment of the Harvard Forest enrichment experiment (15 years after the initiation of the experiment) showed 50 $\%$ greater annual net primary production in the hardwood high $\mathrm{N}$ plot relative to control, while low $\mathrm{N}$ and $\mathrm{N}$ plus $\mathrm{S}$ treatments showed $11 \%$ greater and $6 \%$ lower production, respectively, than control. Over the same time period, the hardwood stands experienced greater mortality with $\mathrm{N}$ additions; for example, the control, low $\mathrm{N}$ and high $\mathrm{N}$ plots resulted in $10 \%, 23 \%$, and $31 \%$ mortality, respectively. Of all species evaluated, red maples suffered the greatest mortality directly after a drought, which shows the susceptibility of hardwood stands to loss of resistance with environmental stress (Magill et al. 2004).

Other $\mathrm{N}$ fertilization experiments reported a net loss in live basal area with increased mortality (Wallace et al. 2007, McNulty et al. 2005). The study by Wallace et al. (2007) was performed in an upland mixed-oak forest in New York. Tree mortality was greater in the fertilized plots, even though there was significant growth of live trees in the fertilized

plots compared to the control plots. The trees that showed the greatest (35\%) mortality in 
the fertilized stands were chestnut and red oaks. The occurrence of significantly increased tree growth and significant mortality can be explained by the forest's stage of $\mathrm{N}$ saturation; Wallace et al. (2007) have concluded that the fertilized plots are in an intermediate stage of $\mathrm{N}$ saturation where those trees less sensitive to $\mathrm{N}$ saturation undergo a fertilizer effect, while those trees more sensitive to $\mathrm{N}$ saturation experience mortality.

The results from the Harvard Forest and New York oak studies are similar, but the differences can be attributed to the species composition of the forests, site quality and past land use history. The New York study sites are dominated by oak species, which are very susceptible to $\mathrm{N}$ additions as indicated by the high rates of mortality (Wallace et al. 2007). Increased mortality of the oaks was attributed to the soil acidification on the sites as indicated by a lower Ca:Al ratio in soil. Site quality of the New York forest was also lower than that at the Harvard Forest as they are at a ridge-top and have thinner soils (Wallace et al. 2007). Land use history of the two sites must also be considered because the onset and continuation of the fertilization effect at the Harvard Forest was much more rapid than that at the New York stands. A history of intense management of the land at Harvard Forest, including clearing for agriculture, may have caused severe $\mathrm{N}$ limitation (Magill et al. 2004). A southern Appalachian N deposition gradient experiment has also shown that tree species react differently to greater $\mathrm{N}$ inputs; sugar maples responded with a fertilizer effect and increased growth (Boggs et al. 2005) while American beech and yellow birch growth declined. 
Coniferous species reactions in fertilization experiments are much more rapid and intense, according to the results of Magill et al. (2004) and McNulty et al. (2005). The Harvard Forest conifer sites exhibited a $56 \%$ decline in tree productivity after 15 years and complete mortality is predicted for the near future (Magill et al. 2004). The red spruce stands in Vermont have also experienced a decline (40\%) in productivity after 14 years and McNulty et al. (2005) suggested that if $\mathrm{N}$ deposition continues at an elevated rate, high elevation spruce forests could be converted into stands of birch and maple. The similar results for these two experiments imply the susceptibility of conifer ecosystems to increased $\mathrm{N}$ deposition. Even though the onset of $\mathrm{N}$ saturation symptoms in conifer forests may appear faster, deciduous forests are equally susceptible to the same fate. Boggs et al. (2005) have shown that American beech and yellow birch have reached the stage of $\mathrm{N}$ saturation, which decreased their productivity, with ambient $\mathrm{N}$ deposition. The reason for the delayed onset of negative impacts from $\mathrm{N}$ additions in deciduous forests may be related to soils with higher buffering capacity; therefore all forest types will have a different response to excess $\mathrm{N}$ (Boggs et al. 2007).

Vegetative uptake of nutrients by forests is controlled by their requirements for growth and production, which varies with stand condition, age, species composition, soil nutrient content, and levels of atmospheric deposition. Acidic deposition in forests especially impacts the cycling of nutrients, particularly cation distribution and leaching rates (Johnson 1992, Adams et al. 2000). A comparison between a pristine forest stand and a forest with a high rate of acid deposition, the leaching rates of $\mathrm{Ca}, \mathrm{Mg}$ and $\mathrm{K}$ were much higher at the acidified site; however the woody tissue showed an accumulation of $\mathrm{Ca}$ and 
K, while vegetation at the pristine sites did not (Johnson 1992). Increased cation leaching losses have been observed in the Fernow watershed acidification study; the watershed that received ammonium sulfate amendments saw higher base cation concentrations in stream water and was attributed to increased mobility of cations, especially $\mathrm{Ca}$ (Edwards et al. 2006). Similarly, wood tissue on the treatment watershed showed decreased Ca concentrations along with increased $\mathrm{N}$ concentrations (DeWalle et al. 2006). This pattern on the treatment watershed was attributed to an increase in $\mathrm{NO}_{3}{ }^{-}$production and leaching, which caused $\mathrm{Ca}$ leaching as well. First, an increase in $\mathrm{Ca}$ and $\mathrm{Mg}$ levels were seen in black cherry, yellow-poplar and red maple under fertilized conditions for the first four years, indicating base cation mobilization. However, after eight to twelve years, base cation depletion occurred in the fertilized watershed as $\mathrm{Ca}$ and $\mathrm{Mg}$ levels in woody tissue and soil solution were higher on control plots.

\subsection{Belowground biomass and nutrient concentrations}

Root growth and aboveground productivity can be limited due to reduced uptake of important nutrients. There are three competing hypotheses that predict the impact of fertilization on fine root biomass. First, fine roots act as a large sink for N (Magill et al. 1997), but several experiments reported decreases in root biomass after fertilization as plants expended less energy on nutrient uptake with greater soil $\mathrm{N}$ concentration (Hendricks et al. 1993, Nadelhoffer et al. 1985, Adams et al. 1995). A second possibility is an increase in fine root biomass (Magill et al. 1997, Pregitzer et al. 2000, Nadelhoffer et al. 1985). An experiment performed in southeast Michigan showed the mean biomass 
of fine roots $(<0.5 \mathrm{~mm})$ was $194 \%$ greater in high-N soil when compared to the low-N treatment (Pregitzer et al. 2000). The third possible response is to have no effect on root biomass, as seen in a fertilization experiment in the Netherlands (Gundersen et al. 1998) as well at the Harvard Forest (Magill et al. 2000). These mixed results suggest that the response of roots to $\mathrm{N}$ fertilization may be site-specific, because roots growing in richer soils may react differently than those in poorer soils.

Weathering, cation exchange, and soil leaching are inorganic processes that drive the cycles of base cations, but under conditions of increased acidic atmospheric deposition, the hydrogen ion $\left(\mathrm{H}^{+}\right)$directly influences the flux of $\mathrm{Ca}, \mathrm{Mg}$ and $\mathrm{P}$ by cation exchange or increased weathering (Johnson 1992). Aluminum is an element of concern because as soil $\mathrm{pH}$ decreases, $\mathrm{Al}$ is more available for uptake instead of cations like $\mathrm{Ca}$ and $\mathrm{Mg}$. Therefore, nutrient availability in the soil has been shown to affect the growth and concentration of ions in fine roots. The NITREX root experiment carried out in a Norway spruce stand in Sweden (Persson et al. 1998) showed an improvement in fine root nutritional status under decreased $\mathrm{N}$ and $\mathrm{S}$ availability; concentrations of $\mathrm{K}, \mathrm{P}$ and $\mathrm{Ca}$ in fine roots increased, and $\mathrm{N}$ concentrations decreased. Root growth was also measured over time on the control and $\mathrm{N}$ addition sites; root growth declined under increased $\mathrm{N}$ inputs. Also, roots in acidified soils decreased their uptake of $\mathrm{Mg}$ and $\mathrm{K}$ (Braun et al. 2005). Another acidification experiment carried out in the northeastern U.S. showed induced $\mathrm{Al}, \mathrm{Fe}$, and $\mathrm{P}$ mobilization; fertilized hardwood stands resulted in greater $\mathrm{P}$ cycling, therefore more $\mathrm{P}$ was available for vegetative uptake (Sherman et al. 2006). 


\subsection{Objectives of this study}

The objective of our experiment was to understand of the impacts of simulated acidic deposition on a young, aggrading, and deciduous forest ecosystem. The Long-Term Soil Productivity (LTSP) study in the Fernow Experimental Forest (FEF) served as the study area and was initiated in 1996 with three treatments that were whole-tree harvested and allowed to naturally regenerate. One treatment included no fertilizer amendments (WT), another received ammonium sulfate at two times the annual ambient rate (WT+NS), and the last received ammonium sulfate at the same rate plus dolomitic lime additions that were two times the rate of calcium and magnesium export to local stream waters (WT+NS+CA) (Adams et al. 2004). The lime treatment was implemented to test for ameliorative effects on increased rates of acidic deposition. Specifically, we wanted to examine treatment effects on forest productivity by studying the ability of this forest to produce above- and belowground biomass; nutrient relations were also observed within that biomass. The scope of the proposed work involved determining the biomass and various nutrient concentrations of aboveground live stems and branches and live and dead fine roots in the LTSP site. Aboveground wood biomass projections for the three treated stands were also carried out using the computer program SILVAH.

\subsection{Hypotheses}

The hypotheses we tested for are outlined below: 
1. Total aboveground wood biomass is greater on the fertilized plots (WT+NS and $\mathrm{WT}+\mathrm{NS}+\mathrm{CA}$ ) compared to the control plots (WT). This is expected to occur because the forests at the LTSP site are young and fast-growing; they may therefore be able to acquire and utilize the nutrients from the fertilizer applications more readily to support faster growth rates than the unfertilized stands.

2. Stem wood tissue is expected to have higher $\mathrm{N}$ concentrations, but lower $\mathrm{Mg}$ and Ca nutrient concentrations in the WT+NS treatment than in the WT treatment; the $\mathrm{WT}+\mathrm{NS}+\mathrm{CA}$ treatment should have greater $\mathrm{Mg}$ and $\mathrm{Ca}$ concentrations due to dolomite additions. Phosphorous is hypothesized to have greater concentrations in woody biomass due to its increased cycling in sites with fertilizer additions. Finally, with greater $\mathrm{N}$ supply in the soil, $\mathrm{N}$ concentrations in wood tissue will be higher in the $\mathrm{WT}+\mathrm{NS}$ and $\mathrm{WT}+\mathrm{NS}+\mathrm{CA}$ treatments.

3. Root biomass is hypothesized to be lower in the fertilized plots (WT+NS and $\mathrm{WT}+\mathrm{NS}+\mathrm{CA}$ ) compared to the control treatment (WT). If more $\mathrm{N}$ is available for root uptake, less energy is needed to for root growth to seek out $\mathrm{N}$ necessary for plant growth.

4. Fine root concentrations of $\mathrm{Ca}$ and $\mathrm{Mg}$ should be higher in the control treatment (WT) compared to the fertilized treatments (WT+NS and WT+NS+CA). Phosphorus is expected to have greater fine root concentrations on fertilized sites $(\mathrm{WT}+\mathrm{NS}$ and $\mathrm{WT}+\mathrm{NS}+\mathrm{CA})$ compared to control sites due to greater $\mathrm{P}$ cycling from fertilization. Lastly, the fertilized plots are hypothesized to have higher fine root $\mathrm{N}$ concentrations. 


\subsection{Literature Cited}

Aber, J.D.; Nadelhoffer, K.J.; Steudler, P.; Melillo, J.M. 1989. Nitrogen saturation in northern forest ecosystems. BioScience. 39: 378-386.

Aber, J.D.; Magill, A.; Boone, R.; Melillo, J.M; Steudler, P.; Bowden, R. 1993. Plant and soil responses to chronic nitrogen additions at the Harvard Forest, Massachusetts. Ecological Applications. 3: 156-166.

Adams, M.B.; Kochenderfer, J.N.; Angradi, T.R.; Edwards, P.J. 1995. In: Gottschalk, Kurt W.; Fosbroke, Sandra L. C., ed. Proceedings, 10th Central Hardwood Forest Conference; 1995 March 5-8; Morgantown, WV.: Gen. Tech. Rep. NE-197. Radnor, PA: U.S. Department of Agriculture, Forest Service, Northeastern Forest Experiment Station. 119-130.

Adams, M.B.; Burger, J.A.; Jenkins, A.B.; and Zelazny, L. 2000. Impact of harvesting and atmospheric pollution on nutrient depletion of eastern US hardwood forests. Forest Ecology and Management. 138: 301-319.

Adams, M.B.; Burger, J.; Zelazny, L.; Baumgras, J. 2004. Description of the Fork Mountain long-term soil productivity study: site characterization. Gen. Tech. Rep. NE323. Newtown Square, PA: U.S. Department of Agriculture, Forest Service, Northeastern Research Station. 40 p. 
Andersson, S.; Nilsson, I.; Valeur, I. 1999. Influence of dolomitic lime on DOC and DON leaching in a forest soil. Biogeochemistry. 47: 297-317.

Bigelow, S.W. \& Canham, C.D. 2007. Nutrient limitation of juvenile trees in a northern hardwood forest: calcium and nitrate are preeminent. Forest Ecology and Management. 243: 310-319.

Boggs, J.L.; McNulty, S.G.; Gavazzi, M.J.; Myers, J.M. 2005. Tree growth, foliar chemistry, and nitrogen cycling across a nitrogen deposition gradient in southern Appalachian deciduous forests. Canadian Journal for Forest Resources. 35: 1901-1913.

Boggs, J.L.; McNulty, S.G.; Pardo, L.H. 2007. Changes in conifer and deciduous forest foliar and forest floor chemistry and basal area tree growth across a nitrogen $(\mathrm{N})$ deposition gradient in the northeastern US. Environmental Pollution. 149: 303-314.

Braun, S.; Cantaluppi, L.; Fluckiger, W. 2005. Fine roots in stands of Fagus sylvatica and Picea abies along a gradient of soil acidification. Environmental Pollution. 137: 574-579.

DeWalle, D.R.; Kochenderfer, J.N.; Adams, M.B.; Miller, G.W.; Gilliam, F.S.; Wood, F.; Odenwald-Clemens, S.S.; Sharpe, W.E. 2006. Vegetation and acidification. In: Adams, M.B.; DeWalle, D.R.; Hom, J.L., eds. The Fernow watershed acidification study. Dordrecht, Netherlands: Springer: 137-188. 
Edwards, P.J.; Williard, K.W.J.; Wood, F.; Sharpe, W.E. 2006. Soil water and stream water chemical responses. In: Adams, M.B.; DeWalle, D.R.; Hom, J.L., eds. The Fernow watershed acidification study. Dordrecht, The Netherlands: Springer: 71-136.

Fernandez, I.J; Rustad, L.E.; Norton, S.A.; Kahl, J.S.; Cosby, B.J. 2003. Experimental acidification causes soil base-cation depletion at the Bear Brook Watershed in Maine. Soil Science Society of America Journal. 67: 1909-1919.

Galloway, J.N.; Dentener, F.J.; Capone, D.G.; Boyer, E.W.; Howarth, R.W.; Seitzinger, S.P.; Asner, G.P.; Cleveland, C.C.; Green, P.A.; Holland, E.A.; Karl, D.M.; Michaels, A.F.; Porter, J.H.; Townsend, A.R.; Vorosmarty, C.J. 2004. Nitrogen cycles: past, present, and future. Biogeochemistry 70: 153-226.

Groffman, P.M.; Fisk, M.C.; Driscoll, C.T.; Likens, G.E.; Fahey, T.J.; Eagar, C.; Pardo, L.H. 2006. Calcium additions and microbial nitrogen cycle processes in a northern hardwood forest. Ecosystems. 9:1289-1305.

Gundersen, P.; Emmett, B.A.; Kjonaas, O.J.; Koopmans, C.J.; Tietema, A. 1998. Impact of nitrogen deposition on nitrogen cycling in forests: a synthesis of NITREX data. Forest Ecology and Management. 101: 37-55. 
Hamburg, S.P.; Yanai, R.D.; Arthur, M.A.; Blum, J.D.; Siccama, T.G. 2003. Biotic control of calcium cycling in northern hardwood forests: acid rain and aging forests. Ecosystems 6: 399-406.

Hendricks, J.J.; Nadelhoffer, K.J.; Aber, J.D. 1993. Assessing the role of fine roots in carbon and nutrient cycling. TREE. 8: 174-178.

Johnson, D.W. 1992. Base cations. In: Johnson, D.W.; Lindberg, S.E., eds. Atmospheric deposition and forest nutrient cycling. New York: Springer-Verlag: 233-340.

Long, R.P.; Horsley, S.B.; Lilja, P.R. 1997. Impact of forest liming on growth and crown vigor of sugar maple and associated hardwoods. Canadian Journal of Forest Research. 27: $1560-1573$.

Magill, A.H.; Downs, M.R.; Nadelhoffer, K.J.; Hallett, R.A.; Aber, J.D. 1996. Forest ecosystem response to four years of chronic nitrate and sulfate additions at Bear Brook Watershed, Maine, USA. Forest Ecology and Management. 84: 29-37.

Magill, A.H.; Aber, J.D.; Hendricks, J.J.; Bowden, R.D.; Melillo, J.M.; Steudler, P.A. 1997. Biogeochemical response of forest ecosystems to simulated chronic nitrogen deposition. Ecological Applications. 7: 402-415. 
Magill, A. H.; Aber, J.D.; Berntson, G.M.; McDowell, W.H.; Nadelhoffer, K.J.; Melillo, J.M.; Steudler, P. 2000. Long-term nitrogen additions and nitrogen saturation in two temperate forests. Ecosystems, 3, 238-253.

Magill, A.H.; Aber, J.D.; Currie, W.; Nadelhoffer, K.J.; Martin, M.E.; McDowell, W.H.; Melillo, J.M.; Steudler, P. 2004. Ecosystem response to 15 years of chronic nitrogen additions at the Harvard Forest LTER, Massachusetts, USA. Forest Ecology and Management. 196: 7-28.

McNulty, S.G.; Boggs, J.L.; Aber, J.D.; Rustad, L.; Magill, A. 2005. Red spruce ecosystem level changes following 14 years of chronic $\mathrm{N}$ fertilization. Forest Ecology and Management. 219: 279-291.

Moore, J.-D.; Ouimet, R. 2006. Ten-year effect of dolomitic lime on the nutrition, crown vigor, and growth of sugar maple. Canadian Journal of Forest Research. 36: 1834-1841.

Nadelhoffer, K.J.; Aber, J.D.; Melillo, J.M. 1985. Fine roots, net primary production, and soil nitrogen availability: a new hypothesis. Ecology. 66: 1377-1390.

National Atmospheric Deposition Program. 2008. National Atmospheric Deposition Program 2007 Annual Summary. NADP Data Report 2008-01. Illinois State Water Survey, University of Illinois at Urbana-Champaign, Champaign, IL. 
Persson, H.; Ahlstrom, K.; Clemensson-Lindell, A. 1998. Nitrogen addition and removal at Gardsjon - effects on fine-root growth and fine-root chemistry. Forest Ecology and Management. 101: 199-205.

Pregitzer, K.S.; Zak, D.R.; Maziasz, J.; DeForest, J.; Curtis, P.S.; Lussenhop, J. 2000. Interactive effects of atmospheric $\mathrm{CO}_{2}$ and soil-N availability of fine roots of populus tremuloides. Ecological Applications. 10: 18-33.

Piatek, K.P.; Munasinghe, P.; Peterjohn, W.T.; Adams, M.B.; Cumming, J.R. 2009. Oak contribution to litter nutrient dynamics in an Appalachian forest receiving elevated $\mathrm{N}$ and dolomite. Canadian Journal of Forest Research: 39: 936-944.

Sherman, J.; Fernandez, I.J.; Norton, S.A.; Ohno, T.; Rustad, L.E. 2006. Soil aluminum, iron, and phosphorus dynamics in response to long-term experimental nitrogen and sulfur additions at the Bear Brook Watershed in Maine, USA. Environmental Monitoring and Assessment. 121: 421-429.

Sullivan, T.J.; Fernandez, I.J.; Herlihy, A.T.; Driscoll, C.T.; McDonnell, T.C.; Nowicki, N.A.; Snyder, K.U.; Sutherland, J.W. 2006. Acid-base characteristics of soils in the Adirondack Mountains, New York. Soil Science Society of America Journal. 70: 141152. 
Valeur, I.; Andersson, S.; Nilsson, S.I. 2000. Calcium content of liming material and its effect on sulphur release in a coniferous forest soil. Biogeochemistry. 50: 1-20.

Valeur, I.; Nilsson, S.I.; Andersson, S.; Sjöberg, G. 2002. Net sulphur mineralization in forest soils as influenced by different lime application rates. Soil Biology and Biochemistry. 34: 1291-1298.

Wallace, Z.P.; Lovett, G.M.; Hart, J.E.; Machona, B. 2007. Effects of nitrogen saturation on tree growth and death in a mixed-oak forest. Forest Ecology and Management. 243: 210-218.

Wallenstein, M.D.; Peterjohn, W.T.; Schlesinger, W.H. 2006. N fertilization effects on denitrification and $\mathrm{N}$ cycling in an aggrading forest. Ecological Applications. 16: 21682176.

Wargo, P.M.; Minocha, R.; Wong, B.L.; Long, R.P.; Horsley, S.B.; Hall, T.J. 2002. Measuring changes in stress and vitality indicators in limed sugar maple on the Allegheny Plateau in north-central Pennsylvania. Canadian Journal of Forest Research. 32: 629-641.

Wilmot, T.R.; Ellsworth, D.S.; Tyree, M.T. 1996. Base cation fertilization and liming effects on nutrition and growth of Vermont sugar maple stands. Forest Ecology and Management. 84: 123-134. 
Yanai, R.D.; Siccama, T.G.; Arthur, M.A.; Federer, C.A.; Friedland, A.J. 1999.

Accumulation and depletion of base cations in forest floors in the northeastern United

States. Ecology. 80: 2774-2787. 


\section{Chapter III: Does nitrogen and sulfur deposition affect forest productivity? ${ }^{1}$}

\subsection{Abstract}

We studied the effects of atmospheric nitrogen and sulfur deposition on forest productivity in a ten-year-old, aggrading forest stand at the Fernow Experimental Forest in Tucker County, West Virginia. Forest productivity was expressed as total aboveground wood biomass, which included stem and branch weight of standing live trees. Ten years after stand regeneration and treatment initiation, total aboveground wood biomass was compared among three treatments: whole tree harvest (WT), whole tree harvest plus annual nitrogen and sulfur additions at two times ambient deposition rates (WT+NS), and whole tree harvest plus nitrogen, sulfur (two times ambient), and dolomitic lime $(\mathrm{WT}+\mathrm{NS}+\mathrm{CA})$ additions. Additionally, future stand productivity was estimated for a subsequent 70 years using growth projection simulator SILVAH. Total aboveground wood biomass at ten years was not significantly different among treatments (ANOVA: F $=1.20, \mathrm{p}=0.33, \mathrm{n}=9$ ). Mean total aboveground wood biomass values for the WT, $\mathrm{WT}+\mathrm{NS}$, and $\mathrm{WT}+\mathrm{NS}+\mathrm{CA}$ treatments were: (mean $\pm \mathrm{SD}) 47.5 \mathrm{Mg} \mathrm{ha}^{-1} \pm(15.3), 53.0 \mathrm{Mg}$ $\mathrm{ha}^{-1} \pm(14.3)$, and 51.0 $\mathrm{Mg} \mathrm{ha}^{-1} \pm(15.5)$, respectively. The dominant tree species was pin cherry (average aboveground dry weight of the three treatments was $38.2 \mathrm{Mg} \mathrm{ha}^{-1}$ ). Lack of significant differences in the aboveground wood component at the stand level suggests

\footnotetext{
${ }^{1}$ Submitted to Conference Proceedings of Ecology and Management of High-Elevation Forests of the Central and Southern Appalachian Mountains, May 14-15, 2009 in Slatyfork, West Virginia by Brittany A. Johnson, Kathryn B. Piatek, Mary Beth Adams, John R. Brooks
} 
that ten years of twice ambient rates of nitrogen and sulfur deposition and mitigation did not impact the ability of this site to produce woody biomass. At the species level, however, yellow-poplar had significantly higher diameter at breast height and aboveground wood biomass in the $\mathrm{WT}+\mathrm{NS}+\mathrm{CA}$ stands, indicating the potential for $\mathrm{N}, \mathrm{S}$, and $\mathrm{Ca}$ additions to impact individual species growth over forest succession. Projected aboveground wood biomass at stand age 80 was $230.3 \mathrm{Mg} \mathrm{ha}^{-1}, 229.9 \mathrm{Mg} \mathrm{ha}^{-1}$, and 349.7 $\mathrm{Mg} \mathrm{ha}^{-1}$ for the respective treatments WT, WT+NS, and WT+NS+CA. Our results suggest that although $\mathrm{N}$ and $\mathrm{S}$ additions alone do not increase stand growth, N, S, and dolomite additions increase growth of individual species within the first ten years of stand development. Based on this early biomass increase, long-term growth in the $\mathrm{WT}+\mathrm{NS}+\mathrm{CA}$ treatment may increase 34 percent by forest age 80 . 


\subsection{Introduction}

Total global production of anthropogenic nitrogen $(\mathrm{N})$ is currently ten times greater than late- $19^{\text {th }}$ century production rates (Galloway and others 2004). Atmospheric $\mathrm{N}$ deposition to forest ecosystems has increased, especially in the northeastern United States during the last few decades as a result of an increase in factory and automobile fossil fuel burning and emissions from agricultural fertilizer inputs. The increase in $\mathrm{N}$ deposition has led to $\mathrm{N}$ saturation, defined as a condition in which atmospheric inputs of $\mathrm{N}$ exceed the biological demand of an ecosystem (Aber and others 1989). Nitrogen saturation can lead to nitrate leaching to stream waters, a change in species composition, decreased soil carbon (C) to $\mathrm{N}$ ratio, lower foliar and fine root biomass, and a potential decrease in net primary productivity (Aber and others 1989). Increased $\mathrm{N}$ deposition to a forest also may result in increased losses of base elements such as calcium $(\mathrm{Ca})$, magnesium $(\mathrm{Mg})$, and potassium (K) and others such as sulfur (S) and phosphorous (P) (Johnson 1992). Depletion of these essential nutrients may impact the productivity and health of a forest community (Yanai and others 1999, Hamburg and others 2003, Sullivan and others 2006, Bigelow and Canham 2007). For example, Wallace and others (2007) attributed overall decline in live basal area to an $\mathrm{N}$ saturation effect caused by fertilizer additions in a northern New York mixed-oak forest; tree mortality in the fertilized plots was higher even though there was a significant increase in basal area of live trees in the fertilized plots than in control plots. 
Stands that receive high ambient rates of $\mathrm{N}$ deposition, but that have not reached $\mathrm{N}$ saturation, may experience an increase in productivity as $\mathrm{N}$ limitations are relieved. Nitrogen enrichment at the Harvard Forest in Massachusetts (Aber and others 1993, Magill and others 2004) resulted in increased annual net primary productivity, while an N deposition gradient in the southern Appalachians (Boggs and others 2005) demonstrated increased basal area growth in sugar maple trees. Further, hardwood trees respond differently than conifers to $\mathrm{N}$ additions. The conifer sites at the Harvard Forest exhibited 56 percent mortality after 15 years of $\mathrm{N}$ additions and complete mortality was predicted for the near future; hardwood stands experienced 17 percent mortality (Magill and others 2004). Red spruce stands in Vermont also experienced a decline (40 percent) in live basal area after 14 years and it was suggested that high elevation spruce forests could be converted into stands of birch and maple under continued elevated $\mathrm{N}$ deposition (McNulty and others 2005).

The Fernow Experimental Forest (FEF) in Tucker County, West Virginia, experiences some of the highest rates of $\mathrm{N}$ deposition in the U.S., and forest stands display symptoms of N saturation (Peterjohn and others 1996, 1999). The objective of this study was to better understand the impact of atmospheric $\mathrm{N}$ and $\mathrm{S}$ deposition on the production of total aboveground wood biomass and individual tree species' biomass response in a young, aggrading deciduous forest at this location. Further, we were interested in whether the effects can be mitigated with dolomitic lime additions. Our final objective was to estimate, by using a growth simulation model, whether early fertilization in this forest type stimulates biomass accretion through the life of a forest. 


\subsection{Study Area}

We conducted the study at the Long-Term Soil Productivity (LTSP) sites on Fork

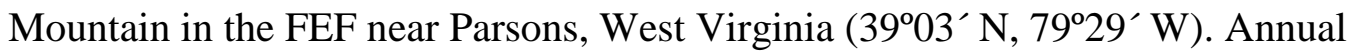
temperatures range from an average of $-2^{\circ} \mathrm{C}$ in January to an average of $20^{\circ} \mathrm{C}$ in July (Adams and others 2004). Precipitation averages $146 \mathrm{~cm}$ annually (Wallenstein and others 2006). Dominant soil type is a Calvin channery silt loam derived from acidic sandstone and shale of the Upper Devonian Hampshire formation (Kochenderfer 2006).

In 1996, four blocks were established along a slope gradient ranging from $798 \mathrm{~m}$ to 847 $\mathrm{m}$ in elevation. Four treatments were imposed in a randomized complete block design, including an unharvested and unfertilized control, unfertilized whole-tree harvested control (WT), whole-tree harvested ammonium sulfate additions (WT+NS), and wholetree harvested ammonium sulfate additions plus dolomitic lime (WT+NS+CA). Individual treatment plots measure 0.2 hectares including treated buffer areas; plots are adjacent to each other within a block. The rate of addition for the WT+NS treatment was two times the ambient $\mathrm{N}$ and $\mathrm{S}$ throughfall deposition. Ambient deposition in early 1980 contained $\sim 15 \mathrm{~kg} \mathrm{~N} \mathrm{ha}^{-1} \cdot \mathrm{yr}^{-1}$ and $17 \mathrm{~kg} \mathrm{~S} \mathrm{ha}^{-1} \cdot \mathrm{yr}^{-1}$ (Helvey and Kunkle 1986); therefore $36 \mathrm{~kg} \mathrm{~N} \mathrm{ha}{ }^{-1} \cdot \mathrm{yr}^{-1}$ and $40 \mathrm{~kg} \mathrm{~S} \mathrm{ha}^{-1} \cdot \mathrm{yr}^{-1}$ are added in fertilizer. The WT+NS+CA plots received two times ambient $\mathrm{N}$ and $\mathrm{S}$ fertilizer as well as $22.5 \mathrm{~kg} \mathrm{Ca} \mathrm{ha}^{-1} \cdot \mathrm{yr}^{-1}$ plus $11.6 \mathrm{~kg}$ $\mathrm{Mg} \mathrm{ha}^{-1} \cdot \mathrm{yr}^{-1}$, which is equivalent to two times the rate of export of $\mathrm{Ca}$ and $\mathrm{Mg}$ to stream water (Wallenstein and others 2006). Pre-treatment mean soil pH was 4.24 (Adams et al. 
2004). Five years after treatment, soil $\mathrm{pH}$ was $2.96,3.22$, and 3.41 in the WT+NS, WT, and WT+NS+CA treatments, respectively (Wallenstein and others 2006).

\subsection{Methods}

Data for three of the four blocks were available for use in this study. Trees were inventoried in 2006 using either four or five 0.004 ha vegetative growth subplots in each plot. Diameter-at-breast-height (d.b.h.) was measured for all trees greater than $2.54 \mathrm{~cm}$ and recorded by species. Total wood dry weight was estimated with regression equations based on d.b.h. For trees 5.1 to $12.7 \mathrm{~cm}$ d.b.h. equations were developed at the Fernow (M.B. Adams, unpublished data); for trees 5.1 to $50.8 \mathrm{~cm}$, equations of Brenneman and others (1978) were used (Table 1). Several tree species did not have their own equation; therefore we used wood specific gravity to match species without an equation to species with a known equation to calculate total aboveground wood dry weight.

Analysis of variance in SAS (SAS Institute Inc. 2002) was used to test for significant differences between treatments in biomass estimates for individual tree species and plot totals. Alpha level of $\leq 0.1$ was used.

A growth model for the Allegheny Hardwoods (SILVAH; Marquis and Ernst 1992) was used to project stand growth to 80 years. Of the available growth simulation computer programs for the Allegheny hardwoods, SILVAH exhibits the least error associated with 
the projections (J.R. Brooks, unpublished data). Data for SILVAH included plot size, tree species, and d.b.h.; growth in SILVAH is estimated by using species-specific basal area growth and mortality equations. Tree per acre (TPA) and basal area values are generated at the stand-level for every five year period.

The SILVAH-generated values for basal area per acre and TPA for each five year increment were used to calculate quadratic mean diameter with Equation 1 for each of the three treatments.

$Q M D=\sqrt{\left(\frac{B A / A C}{T P A}\right)}$

Where:

$Q M D=$ quadradic mean diameter

$B A / A C=$ basal area per acre

TPA $=$ trees per acre

$k=0.0054542$

The quadratic mean diameter for each 5-year period was then used in the species-specific biomass equations (Table 1; see Appendix Table 10 for list of common and scientific names). The biomass for each species in each treatment was multiplied by that individual species' relative density at year ten and then by the total-stand-TPA (Table 2). The sum 
of weights for all species was used to estimate total aboveground wood biomass over the 80 year period. For the purpose of this paper, values are reported in metric units.

SILVAH does not include growth or mortality functions specific to nutrient addition treatments, such as N, S, or liming in growth projections. Therefore, to ensure a level of validity for SILVAH estimates, basal area values from SILVAH at age 35 were compared to mean stand basal area values of 35-year-old forested watersheds at the FEF, which include a control and $\mathrm{N}$ and $\mathrm{S}$ amendments at the same levels as the LTSP treatments (Kochenderfer 2006). The treated watershed had a basal area of $36.0 \mathrm{~m}^{2} \mathrm{ha}^{-1}$ while the control watershed contained $28.0 \mathrm{~m}^{2} \mathrm{ha}^{-1}$ (DeWalle and others 2006). Mean predicted basal area values for the LTSP sites from SILVAH at 35 years were 27.3, 28.0, and 29.1 $\mathrm{m}^{2} \mathrm{ha}^{-1}$, for the WT, WT+NS, and WT+NS+CA treatments, respectively, at 35 years.

\subsection{Results}

\subsubsection{Ten-year-old stands}

\subsubsection{Total aboveground wood biomass and d.b.h.}

There were no significant differences in total aboveground wood biomass between treatments at age ten $(\mathrm{p}=0.33)$; the highest value was $53.0 \pm(14.3) \mathrm{Mg} \mathrm{ha}^{-1}$ in the WT+NS treatment, followed by the WT+NS+CA and WT treatments with $51.0 \pm(15.5)$

and 47.5 $\pm(15.3) \mathrm{Mg} \mathrm{ha}^{-1}$, respectively. Total aboveground wood biomass in each 
treatment is displayed in Figure 1. The WT, WT+NS, and WT+NS+CA treatments had an average d.b.h. of $4.44 \pm(1.75) \mathrm{cm}, 4.62 \pm(1.98) \mathrm{cm}$, and $4.65 \pm(1.98) \mathrm{cm}$, respectively.

\subsubsection{Individual tree species}

Pin cherry (Figure 2) was the most abundant species in these ten-year-old stands regardless of treatment, followed by black cherry and sweet birch, yellow-poplar, red maple, Fraser magnolia, and cucumbertree.

Yellow-poplar and cucumbertree exhibited significantly higher total aboveground wood biomass in the WT+NS+CA treatment ( $\mathrm{p}=0.09$ and 0.10$)$. Aboveground wood biomass of yellow-poplar in the WT+NS+CA treatment was 90 percent higher than in the WT+NS treatment and 79 percent higher than in the WT treatment. Cucumbertree followed a very similar trend in the WT+NS+CA treatment with an 84 percent and 88 percent higher aboveground wood biomass than in the WT+NS and WT treatments, respectively. Yellow-poplar did not have the highest relative density, but its average d.b.h. was significantly higher in the $\mathrm{WT}+\mathrm{NS}+\mathrm{CA}$ treatment compared to the WT and WT+NS treatments $(\mathrm{p}=0.03)$. The average d.b.h. for yellow-poplar in the WT+NS+CA treatment was $5.74 \pm(1.19) \mathrm{cm}$ compared to $3.38 \pm(0.21) \mathrm{cm}$ and $3.40 \pm(0.26) \mathrm{cm}$ in the WT+NS and WT treatments, respectively. Fraser magnolia was the only species that was not present within all treatments; it was absent in the WT+NS+CA treatment plots even though it had a large wood biomass component $\left(14.9 \mathrm{Mg} \mathrm{ha}^{-1}\right)$ in the WT treatment. 
Aboveground wood biomass for red maple was not statistically different between treatments even though average d.b.h. was significantly greater $(4.55 \pm 0.20 \mathrm{~cm})$ in the $\mathrm{WT}+\mathrm{NS}$ treatment compared to the $\mathrm{WT}+\mathrm{NS}+\mathrm{CA}$ treatment $(3.02 \pm 0.55 \mathrm{~cm} ; \mathrm{p}<0.05)$. No other abundant species (pin cherry, black cherry, and sweet birch) showed large variations in diameter or aboveground wood biomass among treatments (Table 2).

\subsubsection{Projected stands}

Although the ten-year-old treated and control stands did not differ in the total aboveground biomass, growth projections (Fig. 3) suggest that around age 30, growth in the WT+NS+CA treatment may exceed the growth in the WT and WT+NS treatments by 16 and 12 percent, respectively. SILVAH's final projection at 80 years yielded a 34 percent higher aboveground wood biomass at $349.7 \mathrm{Mg} \mathrm{ha}^{-1}$ than both the WT and WT+NS treatments (230.3 and $229.9 \mathrm{Mg} \mathrm{ha}^{-1}$, respectively). Greater biomass in the $\mathrm{WT}+\mathrm{NS}+\mathrm{CA}$ treatment can be attributed to differences in quadratic mean diameter between the treatments at 80 years of age. The WT+NS+CA treatment had a 7 percent projected higher quadratic mean diameter $(28.7 \mathrm{~cm})$, than the $26.5 \mathrm{~cm}$ and $26.7 \mathrm{~cm}$ values for the WT and WT+NS treatments, respectively.

\subsection{Discussion}

\subsubsection{Total aboveground wood biomass production of ten-year-old stands}


After ten years of regeneration following whole-tree harvest and elemental additions, which delivered a total of $350 \mathrm{~kg} \mathrm{~N} \mathrm{ha}^{-1}$ and $400 \mathrm{~kg} \mathrm{~S} \mathrm{ha}^{-1}$, total aboveground wood biomass in our study was not significantly affected by either increased $\mathrm{N}$ and $\mathrm{S}$ inputs or liming. In contrast, 23-year-old trees in a watershed-level $\mathrm{N}$ and $\mathrm{S}$ addition study also conducted at the Fernow exhibited significantly higher annual net growth than control trees four years after treatment had begun (DeWalle and others 2006). Other acidification studies have also shown an increase in wood biomass production due to increased $\mathrm{N}$ availability for biomass growth with $\mathrm{N}$ and S additions (Nelleman and Thomsen 2001, Magill and others 2004, Wallace and others 2007).

The lack of differences in biomass between treatments in our study may be attributed to factors associated with the young age of these stands. Full site occupancy (observed as canopy closure) has been reached only recently in these stands, and light and nutrient limitations may not have affected overall stand productivity. Therefore, trees did not yet respond to nutrient additions. Trees that receive $\mathrm{N}, \mathrm{S}(\mathrm{WT}+\mathrm{NS})$, and liming $(\mathrm{WT}+\mathrm{NS}+\mathrm{CA})$ amendments do not yet show a response compared to the WT trees because there appear to be sufficient nutrient resources to support this level of biomass, allowing all sites to be productive. This is supported by soil $\mathrm{N}$ chemistry assessments (Wallenstein et al. 2006) five years into treatment additions at the LTSP site, which demonstrated no difference in soil $\% \mathrm{~N}$, net $\mathrm{N}$ mineralization, and nitrification between all treatments. However, soil $\mathrm{pH}$ was significantly greater in the $\mathrm{WT}+\mathrm{NS}+\mathrm{CA}$ treatment compared to the WT and WT+NS treatments, which may further increase site productivity in this treatment. Already at stand age ten, dolomitic lime additions seem to 
be able to reverse some effects of $\mathrm{N}$ and $\mathrm{S}$ additions. For example, (Piatek et al. 2009) found that ten years of N and S additions (WT+NS) lowered the capacity of foliar litter for $\mathrm{N}$ immobilization and that dolomitic lime reversed the effect.

\subsubsection{Treatment effects at species level}

Even though our study shows no stand-level differences in aboveground wood biomass between treatments, yellow-poplar and cucumbertree have demonstrated significantly more wood biomass accumulation in the WT+NS+CA treatment at ten years. Yellowpoplar has also shown a positive response in basal area growth to $\mathrm{N}$ and $\mathrm{N}+\mathrm{P}$ fertilization due to higher foliar N concentrations (Auchmoody and Smith 1977) resulting in higher rates of photosynthesis. Similar species results were observed in the FEF watershed study; growth plots dominated by yellow-poplar and black cherry on the amended watershed yielded higher relative radial growth rates and basal area increment for seven years since the start of $\mathrm{N}$ and $\mathrm{S}$ additions; plots with mainly sweet birch and red maple also demonstrated greater cubic volume growth for this time period (DeWalle and others 2006). The greater wood biomass that we observed in some species in the WT+NS+CA treatment compared to the WT and WT+NS treatments is suggestive of differential species responses to soil $\mathrm{pH}$ caused by dolomitic lime additions. This may also be evidence of beginning competition for nutrient resources in these stands.

Pin cherry had the highest basal area, relative density, and aboveground wood biomass in all treatments (WT, WT+NS, and WT+NS+CA) in our study. The prevalence of pin 
cherry results from its vigorous early successional behavior after a clearcut and from high N soil conditions (Nyland and others 2007) in the LTSP sites. For example, pin cherry has demonstrated greater germination rates with the addition of $\mathrm{N}$ fertilizer (Auchmoody 1979) and with more $\mathrm{N}$ available in soil solution (Bjorkbom and Walters 1986, Nyland and others 2007). However, as an early successional species, pin cherry is expected to be lost from these stands approximately 35 years after stand regeneration due to natural mortality (Marquis 1967, Marks 1974, Heitzman and Nyland 1994, Nyland and others 2007). Therefore, individual species responses to the expected change in species composition in addition to excess $\mathrm{N}$ deposition are inevitable, but are unclear at this point.

\subsubsection{Potential future stand productivity}

Growth projections with SILVAH suggest that the WT+NS+CA treatment will be most productive by 80 years of age, producing 34 percent more aboveground wood biomass than the WT and WT+NS treatments. SILVAH is not sensitive to treatment in that it does not use treatment-specific equations for biomass growth. Therefore, differences in projected growth among treatments are likely driven by increased diameters of yellowpoplar and cucumbertree at age ten. There are no replicates of the liming amendments at the watershed-scale at the FEF to compare with these results, but estimates from SILVAH provide an insight as to how the $\mathrm{WT}+\mathrm{NS}+\mathrm{CA}$ treatment may result in greater tree productivity of a hardwood stand over a complete rotation. Alternatively, these results may indicate the potential of a lower soil $\mathrm{pH}$, as seen in the WT and WT+NS 
treatments (Wallenstein et al. 2006), to reduce forest productivity compared to the $\mathrm{WT}+\mathrm{NS}+\mathrm{CA}$ treated plots. The reportedly lower soil $\mathrm{pH}$ may have altered cation availability, most notably $\mathrm{Ca}$, which can explain the observed species responses to a decade of dolomitic lime additions. The way in which acidification ultimately impacts species composition and stand productivity at the LTSP site has important implications for C-sequestration and financial returns for landowners.

\subsection{Conclusions}

The results from this study suggest that stand-level total aboveground wood biomass, therefore apparent productivity, has not been affected by increased acidic deposition or liming additions after ten years. SILVAH results and comparisons of individual species' diameters between treatments indicate the $\mathrm{WT}+\mathrm{NS}+\mathrm{CA}$ sites may have higher productivity over the next several decades. The increase in diameter growth in yellowpoplar and cucumbertree alongside the changes that have resulted in soil $\mathrm{pH}$ in the $\mathrm{WT}+\mathrm{NS}+\mathrm{CA}$ treatment suggest that liming may be effective at ameliorating acidified soil conditions. These results also imply that forested sites that receive high rates of ambient $\mathrm{N}$ deposition may experience reduced productivity compared to sites that receive dolomitic lime amendments. Therefore, liming applied to forests that experience elevated levels of $\mathrm{N}$ deposition, have acidic soils, and similar stand composition to the LTSP sites has the potential to increase aboveground wood biomass; this would likely result in a greater financial return for the landowner. 


\subsection{Literature Cited}

Aber, J.D.; Nadelhoffer, K.J.; Steudler, P.; Melillo, J.M. 1989. Nitrogen saturation in northern forest ecosystems. BioScience. 39: 378-386.

Aber, J.D.; Magill, A.; Boone, R.; Melillo, J.M.; Steudler, P.; Bowden, R. 1993. Plant and soil responses to chronic nitrogen additions at the Harvard Forest, Massachusetts. Ecological Applications. 3: 156-166.

Adams, M.B.; Angradi, T.R.; Kochenderfer, J.N. 1997. Stream water and soil solution responses to 5 years of nitrogen and sulfur additions at the Fernow Experimental Forest, West Virginia. Forest Ecology and Management. 95: 79-91.

Adams, M.B.; Burger, J.; Zelazny, L.; Baumgras, J. 2004. Description of the Fork Mountain long-term soil productivity study: site characterization. Gen. Tech. Rep. NE323. Newtown Square, PA: U.S. Department of Agriculture, Forest Service, Northeastern Research Station. 40 p.

Auchmoody, L.R.; Smith, H.C. 1977. Response of yellow-poplar and red oak to fertilization in West Virginia. Soil Science Society of America Journal. 41: 803-807. 
Auchmoody, L.R. 1979. Nitrogen fertilization stimulates germination of dormant pin cherry seed. Canadian Journal of Forest Research. 9: 514-516.

Bigelow, S.W.; C.D. Canham, C.D. 2007. Nutrient limitation of juvenile trees in a northern hardwood forest: Calcium and nitrate are preeminent. Forest Ecology and Management. 2: 310-319.

Bjorkbom, J.C.; Walters, R.S. 1986. Allegheny hardwood regeneration response to evenage harvesting methods. Res. Pap. NE-581. Broomall, PA: U.S. Department of Agriculture, Forest Service, Northeastern Forest Experiment Station. 13 p.

Boggs, J.L.; McNulty, S.G.; Gavazzi, M.J.; Myers, J.M. 2005. Tree growth, foliar chemistry, and nitrogen cycling across a nitrogen deposition gradient in southern Appalachian deciduous forests. Canadian Journal for Forest Resources. 35: 1901-1913.

Brenneman, B.B.; Frederick, D.J.; Gardner, W.E.; Schoenhofen, L.H.; Marsh, P.L. 1978. Biomass of species and stands of West Virginia hardwoods. In: Pope, P.E., ed. Proceedings of Central Hardwood Forest Conference II; West LaFeyette, IN; Purdue University: 159-178.

DeWalle, D.R.; Kochenderfer, J.N.; Adams, M.B.; Miller, G.W.; Gilliam, F.S.; Wood, F.; Odenwald-Clemens, S.S.; Sharpe, W.E. 2006. Vegetation and acidification. In: Adams, 
M.B.; DeWalle, D.R.; Hom, J.L., eds. The Fernow watershed acidification study. Dordrecht, Netherlands: Springer: 137-188.

Galloway, J.N.; Dentener, F.J.; Capone, D.G.; Boyer, E.W.; Howarth, R.W.; Seitzinger, S.P.; Asner, G.P.; Cleveland, C.C.; Green, P.A.; Holland, E.A.; Karl, D.M.; Michaels, A.F.; Porter, J.H.; Townsend, A.R.; Vorosmarty, C.J. 2004. Nitrogen cycles: past, present, and future. Biogeochemistry 70: 153-226.

Hamburg, S.P.; Yanai, R.D.; Arthur, M.A.; Blum, J.D.; Siccama, T.G. 2003. Biotic control of calcium cycling in northern hardwood forests: acid rain and aging forests. Ecosystems 6: 399-406.

Heitzman, E.; Nyland, R.D. 1994. Influences of pin cherry (Prunus pensylvanica L.f.) on growth and development of young even-aged northern hardwoods. Forest Ecology and Management. 67: 39-48.

Helvey, J.D.; Kunkle, S.H. 1986. Input-out budgets of selected nutrients on an experimental watershed near Parsons, West Virginia. Res. Paper. NE-584. Broomall, PA: U.S. Department of Agriculture, Forest Service, Northeastern Forest Experiment Station. $7 \mathrm{p}$. 
Johnson, D.W. 1992. Base cations. In: Johnson, D.W.; Lindberg, S.E., eds. Atmospheric deposition and forest nutrient cycling. New York: Springer-Verlag: 233-340.

Kochenderfer, J.N. 2006. Fernow and the Appalachian hardwood region. In: Adams, M.B.; DeWalle, D.R.; Hom, J.L., eds. The Fernow watershed acidification study. Dordrecht, The Netherlands: Springer: 17-39.

Magill, A.H.; Aber, J.D.; Currie, W.; Nadelhoffer, K.J.; Martin, M.E.; McDowell, W.H.; Melillo, J.M.; Steudler, P. 2004. Ecosystem response to 15 years of chronic nitrogen additions at the Harvard Forest LTER, Massachusetts, USA. Forest Ecology and Management. 196: 7-28.

Marks, P.L. 1974. The role of pin cherry (Prunus pensylvanica L.) in the maintenance of stability in northern hardwood ecosystems. 44: 73-88.

Marquis, D.A. 1967. Clearcutting in northern hardwoods: Results after 30 years. Res. Pap. NE-85. Upper Darby, PA: U. S. Department of Agriculture, Forest Service, Northeastern Forest Experiment Station. 13 p. 
McNulty, S.G.; Boggs, J.L.; Aber, J.D.; Rustad, L.; Magill, A. 2005. Red spruce ecosystem level changes following 14 years of chronic $\mathrm{N}$ fertilization. Forest Ecology and Management. 219: 279-291.

Nellemann C.; Thomsen M.G. 2001. Long-term changes in forest growth: potential effects of nitrogen deposition and acidification. Water, Air, and Soil Pollution. 128: 197205.

Nyland, R.D.; Bashant, A.L.; Heitzman, E.F.; Verostek, J.M. 2007. Interference to hardwood regeneration in northeastern North America: pin cherry and its effects. Northern Journal of Applied Forestry. 24(1): 52-60.

Peterjohn, W.T.; Adams, M.B.; Gilliam, F.S. 1996. Symptoms of nitrogen saturation in two central Appalachian hardwood forest ecosystems. Biogeochemistry. 35: 507-522.

Peterjohn, W.T.; Foster, C.J.; Christ, M.J.; Adams, M.B. 1999. Patterns of nitrogen availability within a forested watershed exhibiting symptoms of nitrogen saturation. Forest Ecology and Management. 119: 247-257.

Piatek, K.P.; Munasinghe, P.; Peterjohn, W.T.; Adams, M.B.; Cumming, J.R. 2009. Oak contribution to litter nutrient dynamics in an Appalachian forest receiving elevated $\mathrm{N}$ and dolomite. Canadian Journal of Forest Research: 39: 936-944. 
SAS Institute Inc. 2002. SAS User's Guide: Statistics. Version 9.1. SAS Institute Inc., Cary, NC.

SILVAH. Marquis, D.A.; Ernst, R.L. 1992. User's guide to SILVAH: stand analysis, prescription, and management simulator program for hardwood stands of the Alleghenies. Version 4.04. Gen. Tech. Rep. NE_162. Radnor, PA: U.S. Department of Agriculture, Forest Service, Northeastern Forest Experiment Station. 124 p.

Sullivan, T.J.; Fernandez, I.J.; Herlihy, A.T.; Driscoll, C.T.; McDonnell, T.C.; Nowicki, N.A.; Snyder, K.U.; Sutherland, J.W. 2006. Acid-base characteristics of soils in the Adirondack Mountains, New York. Soil Science Society of America Journal. 70: 141152.

Wallace, Z.P.; Lovett, G.M.; Hart, J.E.; Machona, B. 2007. Effects of nitrogen saturation on tree growth and death in a mixed-oak forest. Forest Ecology and Management. 243: 210-218.

Wallenstein, M.D.; Peterjohn, W.T.; Schlesinger, W.H. 2006. N fertilization effects on denitrification and $\mathrm{N}$ cycling in an aggrading forest. Ecological Applications. 16: 21682176. 
Yanai, R.D.; Siccama, T.G.; Arthur, M.A.; Federer, C.A.; Friedland, A.J. 1999.

Accumulation and depletion of base cations in forest floors in the northeastern United

States. Ecology. 80: 2774-2787. 
Table 1. Individual tree species dry weight equations based on d.b.h. $\left(Y=a x^{b}\right)$, where $y=$ total aboveground tree dry weight, $x=$ tree d.b.h., $a$ and $b=$ regression constants. The Fernow equations are in kilograms while Brenneman and others' (1978) equations are in pounds. Results of this study are reported in kilograms.

\begin{tabular}{llccc}
\hline & Tree species & $\mathrm{a}$ & $\mathrm{b}$ & r-square \\
\hline Fernow & Black birch & 1.1064 & 2.4877 & 0.98 \\
& Yellow-poplar & 0.7037 & 2.4806 & 0.99 \\
Black cherry & 0.8833 & 2.6047 & 0.98 \\
& Red maple & 0.9305 & 2.5922 & 0.99 \\
& Pin cherry & 0.8833 & 2.6047 & 0.98 \\
& Striped maple & 0.8833 & 2.6047 & 0.98 \\
& Hercules club & 0.8833 & 2.6047 & 0.98 \\
& Sourwood & 0.9305 & 2.5922 & 0.99 \\
& Sassafras & 0.8833 & 2.6047 & 0.98 \\
& Fraser magnolia & 0.8833 & 2.6047 & 0.98 \\
& & & & \\
& White ash & 2.3626 & 2.4798 & 0.99 \\
& Black locust & 1.5647 & 2.6887 & 0.95 \\
& Cucumbertree & 1.4359 & 2.5622 & 0.98 \\
& Northern red oak & 2.4601 & 2.4572 & 0.95 \\
& Yellow birch & 3.1042 & 2.3753 & 0.97 \\
& Sugar maple & 2.4439 & 2.5735 & 0.98 \\
& E. hophornbeam & 2.0340 & 2.6349 & 0.99 \\
\hline
\end{tabular}

Table 2. Trees per hectare (TPH) used to calculate percent relative density (RD) for the dominant tree species $\geq 2.54 \mathbf{c m}$ d.b.h. by treatment. The "other species" include striped maple, eastern hophornbeam, yellow birch, sassafras, white ash, sugar maple, black locust, northern red oak, and sourwood. The last row represents total values by treatment. Treatments are unfertilized whole tree harvest (WT), whole tree harvest plus annual nitrogen and sulfur additions (WT+NS), and whole tree harvest plus nitrogen, sulfur, and dolomitic lime (WT+NS+CA).

\begin{tabular}{lrrrrrr}
\hline & \multicolumn{2}{c}{ WT } & \multicolumn{2}{c}{ WT+NS } & \multicolumn{2}{c}{ WT+NS+CA } \\
\hline Tree species & TPH & RD (\%) & TPH & RD (\%) & TPH & RD (\%) \\
Pin cherry & 2947 & 46.3 & 2964 & 51.0 & 2806 & 48.0 \\
Black cherry & 776 & 12.2 & 889 & 15.0 & 689 & 12.0 \\
Sweet birch & 1023 & 16.1 & 477 & 8.0 & 494 & 9.0 \\
Yellow-poplar & 689 & 10.8 & 215 & 4.0 & 529 & 9.0 \\
Red maple & 247 & 3.9 & 477 & 8.0 & 566 & 10.0 \\
Fraser & & & & & & \\
magnolia & 195 & 3.1 & 180 & 3.0 & 0 & 0.0 \\
Cucumbertree & 35 & 0.5 & 99 & 2.0 & 247 & 4.0 \\
Other species & 458 & 7.3 & 479 & 8.0 & 477 & 8.3 \\
\hline & & & & & & \\
Total & 6370 & 100 & 5780 & 100 & 5807 & 100 \\
\hline
\end{tabular}




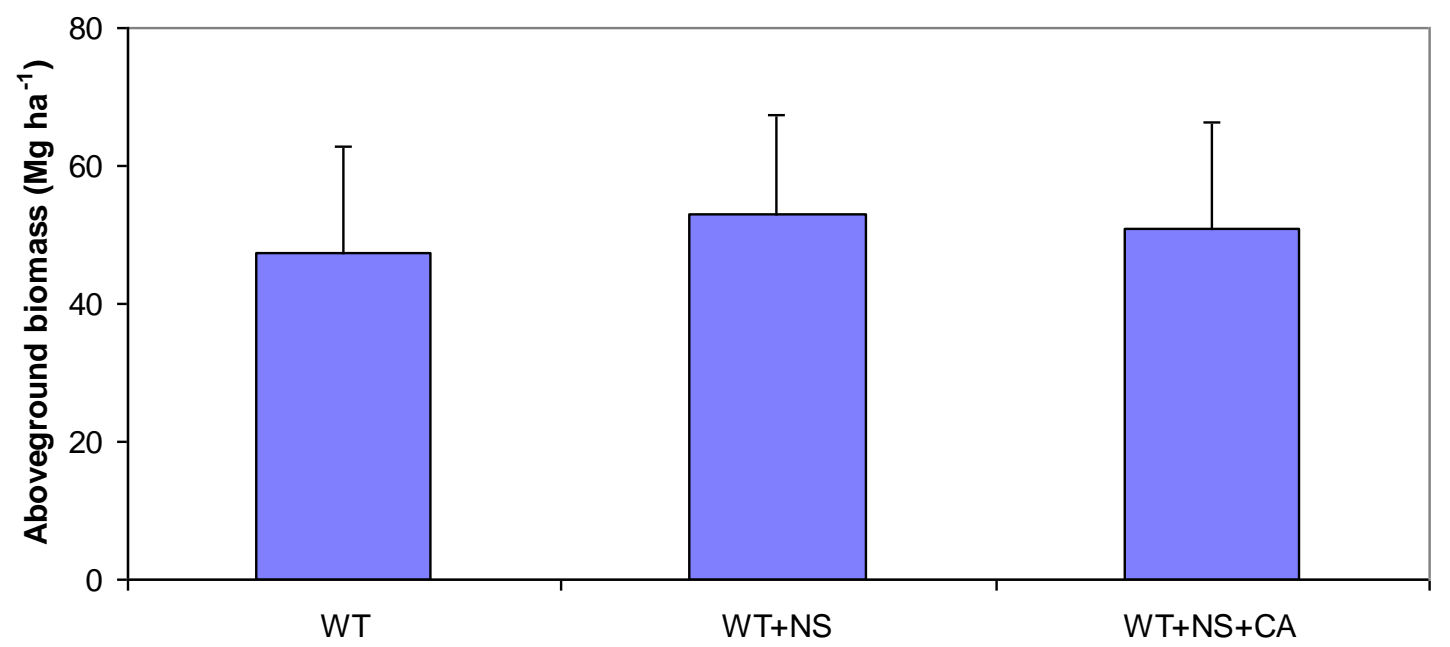

Figure 1. Total aboveground wood biomass values by treatment for the ten-year-old Long-Term Soil Productivity site. Treatments are unfertilized whole tree harvest (WT), whole tree harvest plus annual nitrogen and sulfur additions (WT+NS), and whole tree harvest plus nitrogen, sulfur, and dolomitic lime (WT+NS+CA).

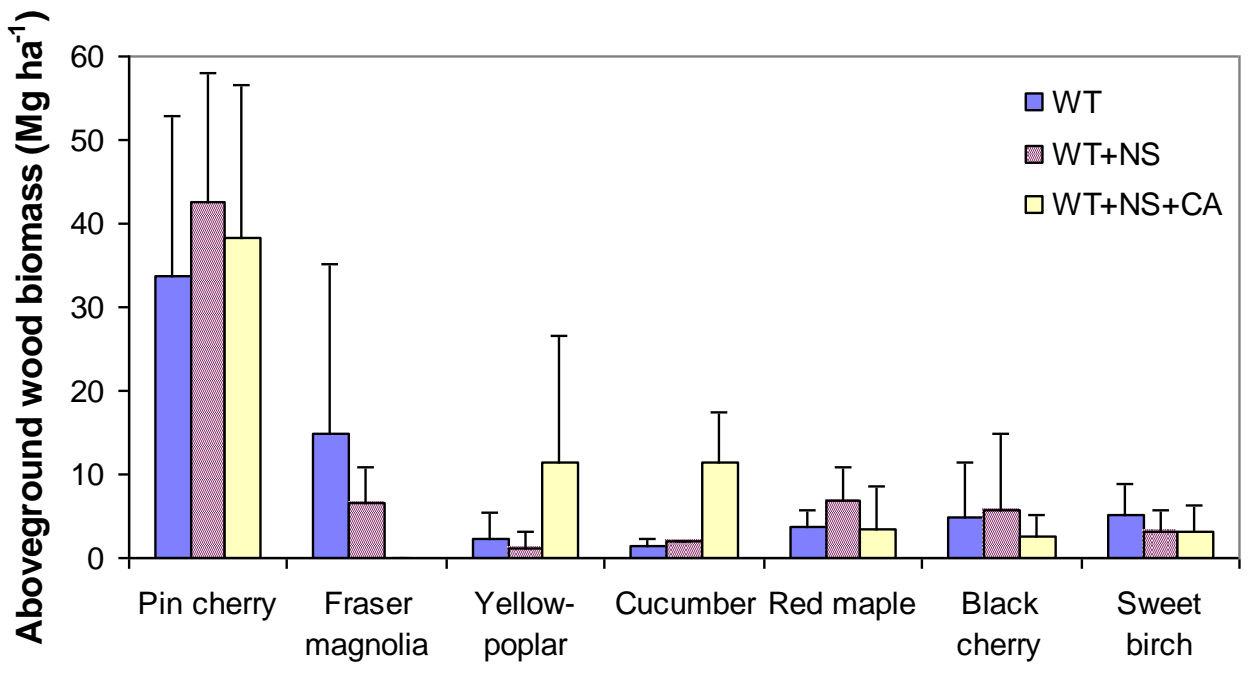

Figure 2. Comparison between treatments of the dominant species' wood biomass component on the Fernow Long-Term Soil Productivity site. Treatments are unfertilized whole tree harvest (WT), whole tree harvest plus annual nitrogen and sulfur additions (WT+NS), and whole tree harvest plus nitrogen, sulfur, and dolomitic lime (WT+NS+CA). 


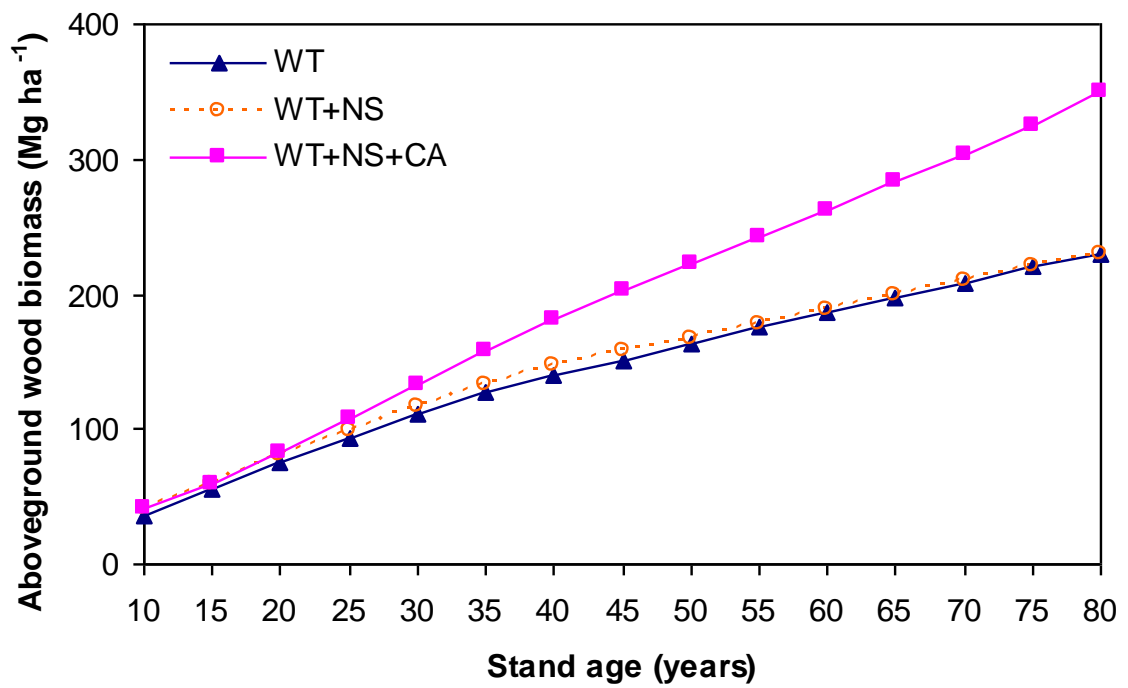

Figure 3. Projected growth in aboveground wood biomass over 80 years by treatment. Treatments are unfertilized whole tree harvest (WT), whole tree harvest plus annual nitrogen and sulfur additions (WT+NS), and whole tree harvest plus nitrogen, sulfur, and dolomitic lime (WT+NS+CA). 


\section{Chapter IV: The effects of nitrogen, sulfur, and lime additions on stem wood nutrition in a young hardwood forest}

\subsection{Abstract}

This study examines the impact of simulated acidic deposition on stem wood nutrition in a young, hardwood forest in West Virginia. The Long-term Soil Productivity (LTSP) site in the Fernow Experimental Forest served as the study site; it was initiated in 1996 with three treatments that were whole-tree harvested and left to naturally regenerate: one received no fertilizer amendments (WT), another received ammonium sulfate at two times the annual ambient rate $(\mathrm{WT}+\mathrm{N})$, and the last received ammonium sulfate at the same rate plus dolomitic lime additions that were two times the rate of calcium and magnesium export to local stream waters $(\mathrm{WT}+\mathrm{N}+\mathrm{CA})$. The lime treatment was implemented to observe its ameliorative effects on increased rates of acidic deposition. Destructive sampling for wood tissue was carried out on the three treatments in 2008 and wood was analyzed for $\mathrm{N}, \mathrm{S}, \mathrm{P}, \mathrm{K}, \mathrm{Ca}, \mathrm{Mg}, \mathrm{Mn}, \mathrm{Fe}, \mathrm{Zn}, \mathrm{Cu}$, and $\mathrm{B}$ concentrations in five of the most abundant species including yellow-poplar, red maple, sweet birch, black cherry, and pin cherry; northern red oak was also examined. Element concentrations were used with estimates of aboveground biomass, which included all four blocks, to calculate aboveground nutrient content between treatments. Results suggest slightly altered wood concentrations of $\mathrm{K}, \mathrm{Ca}$, and $\mathrm{Zn}$ in the WT treatment compared to the $\mathrm{WT}+\mathrm{NS}$ and $\mathrm{WT}+\mathrm{NS}+\mathrm{CA}$ treatments. Greatest concentrations of all nutrients were found in yellowpoplar, northern red oak, and red maple wood tissue, with the exception of $\mathrm{Zn}$, which had 
highest concentrations in sweet birch. Our results show few differences in wood nutrient concentrations, but no differences in aboveground wood biomass between treatments, indicating the resistance of this forest to the effects of acidic deposition. However, the data suggest signs of nutrient stress in the WT+NS treatment due to lower wood Ca:Mn and higher $\mathrm{N}: \mathrm{P}$ nutrient ratios compared to the $\mathrm{WT}$ and $\mathrm{WT}+\mathrm{NS}+\mathrm{CA}$ treatment. Ammonium sulfate additions in this forest therefore have the potential to alter soil and wood chemistry at a young age without affecting aboveground wood biomass production. 


\subsection{Introduction}

Increased rates of acidic deposition to forests in the northeastern United States continue, as evidenced by the National Atmospheric Deposition Program (NADP, 2008). Even though rates of sulfur $(\mathrm{S})$ deposition have decreased compared to nitrogen $(\mathrm{N})$ (Galloway et al. 1995), adverse effects from acid deposition, whether ambient or experimentally applied, are still being reported. Nitrogen saturation (when $\mathrm{N}$ inputs exceed $\mathrm{N}$ demands by an ecosystem) may lead to increased nitrification and nitrate leaching, increased cation leaching, decreased net primary productivity, and decreased fine root mass over the longterm (Aber et al. 1989), and has occurred due to ambient $\mathrm{N}$ deposition in several northeastern forests, (Lovett et al. 2000, McNulty et al. 2005, Wallace et al. 2007) including the Fernow Experimental Forest (Peterjohn et al. 1999). Aboveground biomass production may be negatively impacted due to increased leaching losses of necessary macro- and micro-nutrients (Adams 1999, Magill et al. 2004). Nutrients such as calcium (Ca), magnesium $(\mathrm{Mg})$, potassium $(\mathrm{K})$, and phosphorous $(\mathrm{P})$ are especially susceptible to acidification of forest soils (Johnson 1992, Adams et al. 1997, Tomlinson 2003, Sherman et al. 2006). Young forests, however, may have a better ability to withstand nutrient losses associated with acidic deposition as belowground nutrient competition is low. The research presented here was performed in a young, aggrading deciduous forest in West Virginia; this area experiences some of the highest rates of nitrogen $(\mathrm{N})$ deposition in the eastern U.S. (Adams et al. 2000) and presents an excellent opportunity to examine effects on trees and their aboveground wood nutrient status. 
Analyzing aboveground wood tissue nutrient concentrations and nutrient content is an important way to assess and relate the productivity of trees to soil nutrient status. We have chosen a suite of micro- and macro-nutrients (N, S, P, K, Ca, Mg, manganese (Mn), zinc $(\mathrm{Zn})$, iron $(\mathrm{Fe})$, boron $(\mathrm{B})$, and copper $(\mathrm{Cu}))$ to study as soil acidification has the potential to impact the availability of all listed elements (Lambers et al. 2006). Each macro-element is involved in different physiological roles; $\mathrm{N}$ is the basis for proteins, nucleic acids, and chlorophyll and impacts photosynthetic rates, $\mathrm{S}$ is also found in amino acids, $\mathrm{P}$ is the source of energy in biochemical reactions, $\mathrm{K}$ regulates a neutral charge across membranes as well as stomatal function, $\mathrm{Ca}$ is a large component of cell walls, and Mg plays an important role in photosynthesis (Whittaker et al. 1979, Waring and Running, 1998). The micro-nutrients $\mathrm{Fe}, \mathrm{Cu}, \mathrm{Zn}$, and $\mathrm{Mn}$ are typically involved in enzymatic reactions (Waring and Running, 1998). For example, a particular enzyme containing Mn has a role in splitting a water molecule to allow an electron to be passed to a chlorophyll molecule.

Elemental ratios including $\mathrm{C}: \mathrm{N}, \mathrm{N}: \mathrm{P}$, and $\mathrm{Ca}: \mathrm{Mn}$ are important in revealing limitations of certain nutrients within an ecosystem, especially with regard to soil chemistry. Research by DeWalle et al. $(1995,1999,2003,2006)$ has shown the importance of examining $\mathrm{Ca}: \mathrm{Mn}$ ratios in bolewood in experimentally fertilized sites; these nutrient concentrations in sapwood reflect changes in soil chemistry, most notably soil $\mathrm{pH}$.

The overall objective of this study was to compare macro- and micronutrient concentrations between control, ammonium sulfate amended, and ammonium sulfate and 
dolomitic lime amended stands. We wanted to know whether nutrient concentrations and content differed between treatments and tree species. In an earlier study, there were no differences between treatments in aboveground wood biomass (Chapter 1), which suggested that at age ten, this forest had not yet faced limited nutrient resources in the soil.

\subsection{Study area}

We conducted the study at the Long-Term Soil Productivity (LTSP) sites on Fork Mountain in the Fernow Experimental Forest near Parsons, West Virginia (39 $03^{\prime} \mathrm{N}$, 79²9’ W). Precipitation averages $146 \mathrm{~cm}$ annually (Wallenstein et al. 2006) and average bulk precipitation input is $11.3 \mathrm{~kg} \mathrm{ha}^{-1} \cdot \mathrm{yr}^{-1}$ for inorganic $\mathrm{N}$ (Adams et al. 1997). Dominant soil type is a Calvin channery silt loam derived from acidic sandstone and shale of the Upper Devonian Hampshire formation (Kochenderfer 2006). See Adams et al. (2004) for complete pre-treatment site characterizations.

In 1996, four blocks were established along a slope gradient ranging from $798 \mathrm{~m}$ to 847 $\mathrm{m}$ in elevation. Four treatments were imposed in a randomized complete block design, including an unharvested and unfertilized control, unfertilized whole-tree harvested control (WT), whole-tree harvested ammonium sulfate additions (WT+NS), and wholetree harvested ammonium sulfate additions plus dolomitic lime (WT+NS+CA). Individual growth plots measure 0.2 ha in addition to a $7.6 \mathrm{~m}$ wide buffer strip on each side; plots are adjacent to each other within a block. The rate of addition for the WT+NS 
treatment was two times the ambient $\mathrm{N}$ and $\mathrm{S}$ throughfall deposition. Ambient deposition in early 1980 were $\sim 15 \mathrm{~kg} \mathrm{~N} \mathrm{ha}^{-1} \cdot \mathrm{yr}^{-1}$ and $17 \mathrm{~kg} \mathrm{~S} \mathrm{ha}^{-1} \cdot \mathrm{yr}^{-1}$ (Helvey and Kunkle 1986); therefore $36 \mathrm{~kg} \mathrm{~N} \mathrm{ha}^{-1} \cdot \mathrm{yr}^{-1}$ and $40 \mathrm{~kg} \mathrm{~S} \mathrm{ha}^{-1} \cdot \mathrm{yr}^{-1}$ are added in fertilizer. The $\mathrm{WT}+\mathrm{NS}+\mathrm{CA}$ plots received two times ambient $\mathrm{N}$ and $\mathrm{S}$ fertilizer as well as $22.5 \mathrm{~kg} \mathrm{Ca}$

$\mathrm{ha}^{-1} \cdot \mathrm{yr}^{-1}$ plus $11.6 \mathrm{~kg} \mathrm{Mg} \mathrm{ha}^{-1} \cdot \mathrm{yr}^{-1}$, which is equivalent to two times the rate of export of $\mathrm{Ca}$ and $\mathrm{Mg}$ to stream water (Wallenstein et al. 2006). Pre-treatment mean soil $\mathrm{pH}$ was 4.24 (Adams et al. 2004). Five years after treatment, soil pH was 2.96, 3.22, and 3.41 in the $\mathrm{WT}+\mathrm{NS}, \mathrm{WT}$, and $\mathrm{WT}+\mathrm{NS}+\mathrm{CA}$ treatments, respectively (Wallenstein and others 2006).

\subsection{Methods}

\subsubsection{Nutrient concentrations}

Macro- and micronutrient concentrations of woody tissue from the six species within the WT, WT+NS, and WT+NS+CA treatments were sampled. These species included pin cherry, yellow-poplar, black cherry, sweet birch, and red maple and northern red oak. See Table 10 in Appendix for list of common and scientific names. In July 2008, two stems of each tree species were felled in the buffer zones within each plot in all treatments. One wooden disk was retrieved from each tree and was taken to the forestry lab at West Virginia University to be oven dried. The wood sections (including bark) were cut with a band saw, ground in a Wiley mill, and passed through a $1 \mathrm{~mm}$ mesh screen. The ground samples were then combined by tree species and treatment; $20 \%$ of samples were 
replicated for quality control. Samples were shipped for analysis to Spectrum Analytic (Washington Court House, $\mathrm{OH}$ ). Nutrient analysis included microwave digestion and ICP emission spectroscopy for elements including: $\mathrm{S}, \mathrm{P}, \mathrm{K}, \mathrm{Mg}, \mathrm{Ca}, \mathrm{Mn}, \mathrm{Fe}, \mathrm{Zn}$, and $\mathrm{Cu}$. Nitrogen concentrations were determined by a $\mathrm{CN}$ analyzer and $\mathrm{C}$ concentrations were considered 50 percent of wood biomass for all samples.

\subsubsection{Aboveground wood biomass and nutrient content}

Trees were inventoried in 2006 using four or five 0.004 ha vegetative growth subplots in each plot within all blocks. (Please note that the results for aboveground wood biomass reported in this study are different from Chapter 1 due to the inclusion of data from block IV.) Diameter-at-breast-height $(\mathrm{DBH})$ was measured for all tree species greater than 2.54 $\mathrm{cm}$. Total wood dry weight was estimated with regression equations based on DBH. For trees 5.1 to $12.7 \mathrm{~cm}$ DBH equations were developed at the Fernow and for trees 5.1 to $50.8 \mathrm{~cm} \mathrm{DBH}$ equations of Brenneman and others (1978) were used. Several tree species did not have their own equation, therefore we used wood specific gravity to match species without an equation to species with a known equation to calculate total aboveground wood dry weight.

Nutrient concentrations from the 12-year-old stand were applied to total aboveground wood biomass estimates to determine wood nutrient content in the ten-year-old stands. An average of the six species' elemental concentration was applied to tree species not 
sampled in this study to determine total wood nutrient content by treatment, block, and species.

Statistical analysis software (SAS Institute Inc., 2002) was used to make comparisons between treatments and tree species for all elemental concentrations as well as total aboveground wood nutrient content. The model included main effects of treatment, block, and species and interactions of treatment*species. Differences were deemed significant when alpha was $\leq 0.05$.

\subsection{Results}

\subsubsection{Treatment differences in wood nutrient concentrations}

See Tables 3 and 4 for a list of nutrients and p-values associated with block, treatment, species, and treatment*species interactions. Plots that received amendments of ammonium sulfate and ammonium sulfate plus lime demonstrated very similar trends in wood chemistry, while the control treatment deviated for several nutrients (Figures 4 and 5). For instance, concentrations of $\mathrm{Zn}, \mathrm{Ca}$, and $\mathrm{K}$ in the WT treatment were higher (though not significantly so) compared to those in the WT+NS and WT+NS+CA treatments. The WT treatment had 13 percent lower Fe wood concentrations $(15.50 \mathrm{ppm})$ while $\mathrm{Zn}$ was 21 percent higher in the WT treatment (12.50 ppm) compared to the other treatments. Nitrogen, when averaged across the three treatments, had the highest elemental concentration in wood compared to all other elements $(0.23 \%)$; $\mathrm{Ca}$ and $\mathrm{K}$ 
followed with $0.20 \%$ and $0.11 \%$ wood concentrations, respectively. Sulfur, $\mathrm{P}, \mathrm{Mg}$, and Mn had very similar average concentrations among treatments $(0.01 \%, 0.01 \%, 0.02 \%$, and $0.03 \%$, respectively). Trace metals ranging from highest to lowest concentration, when averaged among tree species, were Mn (253.50 ppm), Fe (17.11 ppm), Zn (10.75 $\mathrm{ppm})$, and $\mathrm{Cu}(1.44 \mathrm{ppm})$. The range of reported trace metal concentrations is not toxic to the trees nor do any of the other macro- and micro-nutrients display levels of severe deficiency.

Nitrogen: P ratios (data not shown) were slightly higher in the WT+NS treatment (18) compared to the WT and WT+NS+CA treatments (both 15), indicating less P or more $\mathrm{N}$ was available and allocated to wood tissue in the WT+NS treatment. The WT+NS and $\mathrm{WT}+\mathrm{NS}+\mathrm{CA}$ treatments had lower $\mathrm{Ca}: \mathrm{Mn}$ ratios in wood tissue (both 9) compared to the WT treatment (10), signifying higher availability of Ca or less Mn in the WT site relative to the ammonium sulfate amended treatments (Figure 6).

\subsubsection{Tree species differences in wood nutrient concentration}

The six sampled tree species and their elemental concentration for the three treatments can be found in Table 5. Generally, pin cherry and sweet birch demonstrated the lowest elemental concentrations compared to the other species, while yellow-poplar, northern red oak, and red maple tended to have the highest concentrations. Even though differences in wood concentration among species were not large, t-tests revealed significant differences between several tree species; treatment*species interaction effects 
were significant for the elements $\mathrm{N}$ and $\mathrm{Zn}$. These differences will be discussed in the following paragraphs.

\subsubsection{Nitrogen}

In terms of treatment*species differences, northern red oak in the WT treatment had the highest $\mathrm{N}$ wood concentration compared to all species in all other treatments $(\mathrm{p}<0.05)$, except yellow-poplar in the WT+NS+CA treatment. Pin cherry had the lowest $\mathrm{N}$ wood concentration in the WT+NS+CA treatment compared to all other species in all other treatments $(\mathrm{p}<0.05)$, except for red maple in the WT+NS+CA treatment, yellow poplar in the WT and WT+NS treatments, and sweet birch in the WT+NS+CA and WT+NS treatments.

\subsubsection{Sulfur}

The main effects of tree species on S concentration indicated that northern red oak and red maple were higher in wood $S$ than black cherry, pin cherry, and sweet birch $(p=0.04)$. There was not a significant treatment*species interaction for sulfur.

\subsubsection{Phosphorous}

Red maple P wood concentrations were significantly higher than pin cherry and sweet birch $\mathrm{P}$ concentrations $(\mathrm{p}=0.03)$. Phosphorous wood nutrient concentrations among tree species were not significant among treatment*species interactions. To show the 
similarities in concentrations of $\mathrm{P}$ between treatments, Figure 7 compares treatment $(\mathrm{T})$ and control (C) wood concentrations (T/C) of $\mathrm{P}$ in wood by species to express higher concentrations $(\mathrm{T} / \mathrm{C}>1)$ or lower concentrations $(\mathrm{T} / \mathrm{C}<1)$. This method normalizes the wood concentration data for any element and shows the level of response of a particular tree species to treatments (DeWalle et al. 1999). The WT+NS+CA treatment shows similar P concentrations in all tree species; the WT+NS treatment exhibited higher P concentrations in black cherry, but lower P concentrations in northern red oak and yellow-poplar.

\subsubsection{Magnesium}

At the species level, yellow-poplar had significantly greater wood Mg than northern red oak $(\mathrm{p}=0.04)$. Treatment*species interactions were not significant for $\mathrm{Mg}$ wood concentrations. The ratio of treatment over control (T/C) wood concentrations of $\mathrm{Mg}$ (Figure 8) demonstrates no differences between treatments for black cherry, pin cherry, red maple, and sweet birch. Northern red oak and yellow-poplar had higher Mg wood concentrations in the $\mathrm{WT}+\mathrm{NS}+\mathrm{CA}$ treatment relative to control. The $\mathrm{WT}+\mathrm{NS}$ treatment exhibited lower wood Mg in northern red oak compared to the control (WT) treatment.

\subsubsection{Calcium}

Calcium wood concentrations among tree species were not significantly different; treatment*species interactions were also not significant. 


\subsubsection{Potassium}

Potassium concentrations were significantly higher in yellow-poplar wood tissue compared to black cherry, pin cherry, and sweet birch $(\mathrm{p}=0.04)$. Treatment*species interaction effects were not significant.

\subsubsection{Manganese}

The tree species with the highest average Mn concentration was red maple, which was significantly greater than black cherry and pin cherry $(\mathrm{p}=0.03$ and 0.02 , respectively). Sweet birch was also significantly higher than pin cherry $(\mathrm{p}=0.03)$.

\subsubsection{Zinc}

Zinc concentrations in sweet birch were significantly (approximately $7 \%$ ) higher compared to all other species and to all other species in all other treatments (both $\mathrm{p}<$ $0.05)$.

\subsubsection{Boron}

Northern red oak, red maple, and yellow-poplar had significantly higher B wood concentrations compared to sweet birch $(\mathrm{p}<0.05)$ when only species effects are examined. Treatment*species interactions were not significant. 


\subsubsection{Copper}

Yellow-poplar had significantly higher wood $\mathrm{Cu}$ concentrations compared to pin cherry $(\mathrm{p}=0.04)$. Treatment*species effects were not significant.

\subsubsection{Total aboveground wood nutrient content}

Total aboveground wood biomass was not significantly different between treatments with the inclusion of block IV, therefore wood nutrient content (the product of total aboveground wood biomass and nutrient concentration) of most elements did not differ significantly (Table 6). Zinc and Mn were exceptions, however, and showed significantly greater nutrient content in the WT treatment for both $(\mathrm{p}=0.01$ and 0.06 , respectively).

Carbon content in live woody tissue in the ten-year-old stand averaged $25,517 \mathrm{~kg} \mathrm{ha}^{-1}$ across treatments. Nitrogen, $\mathrm{K}$, and $\mathrm{Ca}$ also comprised a significant portion in wood content compared to the other macro- and micro-nutrients.

Table 7 shows the estimated aboveground wood biomass for the most abundant tree species by treatment. Pin cherry had significantly higher aboveground wood biomass in the WT+NS+CA and WT+NS treatment compared to the WT treatment, therefore the nutrient content for all elements was higher for pin cherry in WT+NS and WT+NS+CA $(\mathrm{p}=0.03)$. Other species that show significant differences in aboveground wood biomass between treatments were sweet birch and cucumbertree. Cucumbertree had higher aboveground wood biomass in the WT+NS+CA treatment compared to the other two 
treatments and sweet birch had significantly higher biomass in the WT treatment compared to the $\mathrm{WT}+\mathrm{NS}+\mathrm{CA}$ treatment $(\mathrm{p}=0.1$ and 0.05 , respectively); all nutrient content values followed the same trend.

\subsection{Discussion}

\subsubsection{Treatment effects on wood nutrient concentrations and contents}

Strong similarities were evident between the WT+NS and WT+NS+CA treatments in terms of elemental wood concentrations. The WT treatment exhibited a trend toward slightly greater values for the elemental wood concentrations of the elements $\mathrm{Ca}, \mathrm{K}$, and $\mathrm{Zn}$ compared to the other treatments. As these elements play important roles in the physiological function of trees, $\mathrm{Ca}$ as a component of cell walls and $\mathrm{K}$ as an aide in osmotic regulation (Chapin et al. 1997), the potential effects of chronic acidic deposition on nutrient cycling and availability are imperative to understand. Furthermore, because the WT treatment is the only treatment that did not receive amendments of twice-ambient ammonium sulfate, the soil availability of these nutrients may be greater than in the other two treatments.

Nitrogen and $\mathrm{S}$ ions have the capability to displace cations from soil exchange sites (Tomlinson 2003), thereby increasing cation leaching under higher rates of acidic deposition. Therefore, these results provide some support for acidification-related cation leaching. Amendments of dolomitic lime (Mg and $\mathrm{Ca})$ on the $\mathrm{WT}+\mathrm{NS}+\mathrm{CA}$ site did not seem to affect the availability of the cations $\mathrm{Ca}, \mathrm{K}$, and $\mathrm{Zn}$ at this time. The other wood 
nutrient concentrations, including $\mathrm{N}, \mathrm{S}, \mathrm{P}, \mathrm{Mg}, \mathrm{Mn}, \mathrm{Cu}$, and $\mathrm{Fe}$, did not respond to any particular treatment, suggesting that competition for these nutrients is weak, if at all, in this young forest. Other research on the LTSP site also found little difference between treatments in terms of soil $\mathrm{N}$ dynamics; even though $\mathrm{pH}$ significantly increased with dolomite additions, soil $\mathrm{N}$ and $\mathrm{C}(\%)$, net $\mathrm{N}$ mineralization, and nitrification were not significantly affected by five years of treatment (Wallenstein et al. 2006). The lack of significant differences in stem wood chemistry between the LTSP treatments indicates a degree of resistance of young hardwood stands to $\mathrm{N}$ saturation.

In our study, N:P ratios compared among treatments show some evidence of $\mathrm{P}$ limitation in the WT+NS treatment. Phosphorus was less available certain tree species (northern red oak and yellow poplar) in the WT+NS treatment when compared to the WT treatment. Higher concentrations of P may exist in wood tissue in the WT and WT+NS+CA treatments as $\mathrm{P}$ is probably more available for tree uptake due to a slightly higher soil $\mathrm{pH}$ (Fisher and Binkley 2000) in these treatments. Similarly, a study by Piatek et al. (2009) found that the WT+NS+CA and WT treatment had an effect on litter nutrient dynamics; they also found that a potential P limitation to decomposition was more evident than an $\mathrm{N}$ limitation. Pre-treatment foliar data for the LTSP site also indicated the potential for P limitation (Adams et al. 2004), which has been found elsewhere in the Fernow (Gress et al. 2007).

Lower Ca:Mn ratios, or higher levels of Mn, in bolewood may be indicators of stress in trees (DeWalle et al. 1999). The average Ca:Mn ratio among all six tree species was 
lowest in the $\mathrm{WT}+\mathrm{NS}$ treatment. The $\mathrm{Ca}: \mathrm{Mn}$ ratio reported here for red maple is similar to that reported for red maple in the Fernow watershed study; twelve years after treatment the control watershed had a slightly higher Ca:Mn ratio of 7 compared to the Ca:Mn ratio of 6 in the ammonium sulfate treated watershed (DeWalle et al. 2006). The ratios for red maple in the LTSP plots were 8 and 5 for the WT treatment and the average of both WT+NS and WT+NS+CA treatments, respectively. In DeWalle et al.'s (2006) study, bolewood chemistry suggested that the treated watershed had the lowest availability of Ca relative to $\mathrm{Mn}$ in the soil from eight to 12 years after treatment due to cation leaching; these finding are similar to ours and perhaps indicate early signs of $\mathrm{Ca}$ depletion due to soil acidification on the WT+NS site. Litter decomposition studies on the LTSP site (Piatek et al. 2009) and the watershed study (Adams and Angradi 1996) both showed higher concentrations of $\mathrm{N}$ and lower concentrations of $\mathrm{Ca}$ in fresh litter in the ammonium sulfate treated sites compared to the control sites. Even though total aboveground wood biomass has not been affected by simulated acidic deposition in the $\mathrm{WT}+\mathrm{NS}$ treatment in the LTSP site, it seems that the Ca:Mn ratio may indicate the potential for Ca limitations in the soil in the WT+NS plots in the future; Ca depletion has been shown to have deleterious effects on tree productivity (Wilmot et al. 1996).

Significantly greater Zn content was demonstrated in the WT treatment. Zinc's prevalence can be attributed to its high concentration in sweet birch regardless of treatment and highest biomass of sweet birch in WT than in other treatments. Ten-fold higher $\mathrm{Zn}$ concentrations in sweet birch foliage compared to other species were also found in pre-treatment LTSP data (Adams et al. 2004) and at Hubbard Brook, in which 
they suggested being as such for the species' mechanism of defense (Whittaker et al. 1979). The content of Mn was significantly lower in the WT+NS; this is unusual as increased concentrations of Mn generally occur with soil acidification. However, the Fernow watershed study also reported lower Mn soil concentrations seven years after treatment (Tepp, 1995); concentrations may have been diminished in the soil by cation leaching (Adams et al. 2006). Yet, bolewood chemistry in the Fernow watershed study indicated a rise in Mn concentration after eight years of treatment, therefore in time, the LTSP site may also see an accentuated response of this particular element.

\subsubsection{Species-level wood nutrient concentrations}

Northern red oak, yellow-poplar, and red maple tended to have the highest concentrations of nutrients regardless of treatment, except for $\mathrm{Zn}$, in which sweet birch had the highest concentrations for all treatments. The productivity of yellow-poplar is sensitive to nutrient availability and this species may have the ability to out-compete other tree species in terms of growth (Kolb et al. 1990, Schuler and Robison 2008). In this study, yellow-poplar exhibited higher average $\mathrm{DBH}$ values in the $\mathrm{WT}+\mathrm{NS}+\mathrm{CA}$ treatment compared to the WT and WT+NS treatments, perhaps due to greater soil nutrient availability. Red maple also acquired a high concentration of nutrients, which have been used towards tree growth because the average DBH in the WT+NS treatment is significantly higher than red maple in the WT and WT+NS+CA treatments $(\mathrm{p}=0.08)$. 
Wood nutrient concentrations values found in this study are similar to those reported for the Fernow watershed study (DeWalle et al. 1995, Adams et al. 1995) for some elements, but overall they tend to be higher in the LTSP site; concentrations of $\mathrm{Ca}, \mathrm{Mg}, \mathrm{Mn}, \mathrm{Fe}, \mathrm{Zn}$, $\mathrm{N}$, and $\mathrm{S}$ are on average two times greater in the LTSP site. A Hubbard Brook study found similar results to our study in that significantly higher $\mathrm{Mg}$ values were found in younger sugar maple wood compared to older stands (Arthur et al. 1999). Conversely, Arthur et al. (1999) also found significantly higher concentrations of $\mathrm{Ca}$ and $\mathrm{Mg}$ in older wood core segments than younger wood segments for yellow birch. DeWalle et al. (1991) also reported that red oak and black cherry bole wood demonstrated higher elemental concentrations with closer proximity to the cambium (older) tissue. The high concentrations found in our study must reflect site differences in soil chemistry and differences in individual tree species to sequester a variety of macro- and micro-nutrients.

\subsection{Conclusions}

The difference in nutrient concentration between treatments may be indicative of nutrient stress on vegetation in the WT+NS treatment. The WT treatment had greater (though not significantly so) $\mathrm{Ca}, \mathrm{K}$, and $\mathrm{Zn}$ wood concentrations than the other two treatments. The potential for P limitations exist in the WT+NS plots, and Ca had the lowest wood concentrations compared to $\mathrm{Mn}$ in the WT+NS treatment. However, this forest is young and resource competition is weak. The magnitude of stem wood nutrient concentrations found in this study also suggests the site is very fertile, which can undoubtedly support the aggrading vegetation. 
Aboveground biomass was not found to be significantly different between treatments at age ten, therefore, changes in soil nutrient dynamics due to acidic deposition have not affected aboveground productivity at this time. Yet the initial signs of nutrient stress seen in stem wood, especially in the WT+NS treatment, suggest that additions of ammonium sulfate can potentially affect aboveground productivity as a result of altered nutrient dynamics. The differences observed in nutrient concentrations from wood tissue seen in this study may very well be accentuated as these stands age. An imminent decline in aboveground wood biomass caused by chronic acid deposition could have major implications for the forest and $\mathrm{C}$ sequestration. 


\subsection{Literature Cited}

Aber, J.D.; Nadelhoffer, K.J.; Steudler, P.; Melillo, J.M. 1989. Nitrogen saturation in northern forest ecosystems. BioScience. 39: 378-386.

Adams, M.B.; Kochenderfer, J.N.; Angradi, T.R.; Edwards, P.J. 1995. In: Gottschalk, Kurt W.; Fosbroke, Sandra L. C., ed. Proceedings, 10th Central Hardwood Forest Conference; 1995 March 5-8; Morgantown, WV.: Gen. Tech. Rep. NE-197. Radnor, PA:

U.S. Department of Agriculture, Forest Service, Northeastern Forest Experiment Station. 119-130.

Adams, M.B.; Anradi, T.R. 1996. Decomposition and nutrient dynamics of hardwood leaf litter in the Fernow Whole-Watershed Acidification Experiment. Forest Ecology and Management. 83: 61-69.

Adams, M.B.; Angradi, T.R.; Kochenderfer, J.N. 1997. Stream water and soil solution responses to 5 years of nitrogen and sulfur additions at the Fernow Experimental Forest, West Virginia. Forest Ecology and Management. 95: 79-91.

Adams, M.B. 1999. Acidic deposition and sustainable forest management in the central Appalachians, USA. Forest Ecology and Management. 122: 17-28. 
Adams, M.B.; Burger, J.A.; Jenkins, A.B.; and Zelazny, L. 2000. Impact of harvesting and atmospheric pollution on nutrient depletion of eastern US hardwood forests. Forest Ecology and Management. 138: 301-319.

Adams, M.B.; Burger, J.; Zelazny, L.; Baumgras, J. 2004. Description of the Fork Mountain long-term soil productivity study: site characterization. Gen. Tech. Rep. NE323. Newtown Square, PA: U.S. Department of Agriculture, Forest Service, Northeastern Research Station. 40 p.

Adams, M.B.; DeWalle, D.R.; Peterjohn, W.T.; Gilliam, F.S.; Sharpe, W.E.; Williard, K.W.J. Soil chemical response to experimental acidification treatments. In: Adams, M.B.; DeWalle, D.R.; Hom, J.L., eds. The Fernow watershed acidification study. Dordrecht, The Netherlands: Springer: 41-69.

Arthur, M.A.; Siccama, T.G.; Yanai, R.D. 1999. Calcium and magnesium in wood of northern hardwood forest species: relations to site characteristics. Canadian Journal of Forest Research. 29: 339-346.

Brenneman, B.B.; Frederick, D.J.; Gardner, W.E.; Schoenhofen, L.H.; Marsh, P.L. 1978. Biomass of species and stands of West Virginia hardwoods. In: Pope, P.E., ed. Proceedings of Central Hardwood Forest Conference II; West LaFeyette, IN; Purdue University: 159-178. 
Chapin III, F.S.; Matson, P.A.; Mooney, H.A. 2002. Principles of terrestrial ecosystem ecology. New York: Springer. 436p.

DeWalle, D.R.; Swistock, B.R.; Sharpe, W.E. 1991. Radial patterns of tree-ring chemical element concentration in two Appalachian hardwood stands. In: McCormick, Larry H.; Gottschalk, Kurt W., eds. Proceedings, 8th Central Hardwood Forest Conference; 1991 March 4-6; University Park, PA. Gen. Tech. Rep. NE-148. Radnor, PA: U.S. Department of Agriculture, Forest Service, Northeastern Forest Experiment Station: 459-474.

DeWalle, D.R.; Tepp, J.S.; Pickens, C.J.; Edwards, P.J.; Sharpe, W.E. 1995. In: Gottschalk, Kurt W.; Fosbroke, Sandra L. C., ed. Proceedings, 10th Central Hardwood Forest Conference; 1995 March 5-8; Morgantown, WV.: Gen. Tech. Rep. NE-197. Radnor, PA: U.S. Department of Agriculture, Forest Service, Northeastern Forest Experiment Station. 119-130.

DeWalle, D.R.; Tepp, J.S.; Swistock, B.R.; Sharpe, W.E.; Edwards, P.J. 1999. Tree-ring cation response to experimental watershed acidification in West Virginia and Maine. Journal of Environmental Quality. 28: 299-309.

DeWalle, D.R.; Tepp, J.S.; Swistock, B.R.; Edwards, P.J.; Sharpe, W.E.; Adams, M.B.; Kochenderfer, J.N. 2003. In: Van Sambeek, J.W.; Dawson, J.O.; Ponder, F., Jr.; 
Loewenstein, E.F.; Fralish, J.S., eds. Proceedings, $13^{\text {th }}$ Central Hardwood Forest conference; 2002 April 1-3; Urbana, IL. Gen. Tech. Rep. NC-234. St. Paul, MN: U.S. Department of Agriculture, Forest Service, North Central Research Station. 565 p.

DeWalle, D.R.; Kochenderfer, J.N.; Adams, M.B.; Miller, G.W.; Gilliam, F.S.; Wood, F.; Odenwald-Clemens, S.S.; Sharpe, W.E. 2006. Vegetation and acidification. In: Adams, M.B.; DeWalle, D.R.; Hom, J.L., eds. The Fernow watershed acidification study. Dordrecht, Netherlands: Springer: 137-188.

Fisher, R.F.; Binkley, D. 2000. Ecology and management of forest soils. New York: John Wiley and Sons, Inc. 489 p.

Galloway, J.N.; Schlesinger, W.H.; Levy, J.; Michaels, A.; Schnoor, J.L. 1995. Nitrogen fixation: anthropogenic enhancement, environmental response. Global Biogeochemical Cycles. 9: 235-252.

Gress, S.E.; Nichols, T.D.; Northcraft, C.C.; Peterjohn, W.T. 2007. Nutrient limitation in soils exhibiting differing nitrogen availabilities: what lies beyond nitrogen saturation? Ecology. 88(1): 119-130. 
Helvey, J.D.; Kunkle, S.H. 1986. Input-out budgets of selected nutrients on an experimental watershed near Parsons, West Virginia. Res. Paper. NE-584. Broomall, PA: U.S. Department of Agriculture, Forest Service, Northeastern Forest Experiment Station. $7 \mathrm{p}$.

Johnson, D.W. 1992. Base cations. In: Johnson, D.W.; Lindberg, S.E., eds. Atmospheric deposition and forest nutrient cycling. New York: Springer-Verlag: 233-340.

Kochenderfer, J.N. 2006. Fernow and the Appalachian hardwood region. In: Adams, M.B.; DeWalle, D.R.; Hom, J.L., eds. The Fernow watershed acidification study. Dordrecht, The Netherlands: Springer: 17-39.

Kolb, T.E.; Steiner, K.C.; McCormick, L.H.; Bowersox, T.W. 1990. Growth response of northern red-oak and yellow-poplar seedlings to light, soil moisture and nutrients in relation to ecological strategy. Forest Ecology and Management. 38: 65-78.

Lambers, H.; Chapin III, F.S.; Pons, T.L. 2006. Plant physiological ecology. New York: Springer. $540 \mathrm{p}$. 
Lovett, G.M.; Weathers, K.C.; Sobczak, W.V.; 2000. Nitrogen saturation and retention in forested watersheds of the Catskill Mountains, New York. Ecological Applications. 10: 73-84.

Magill, A.H.; Aber, J.D.; Currie, W.; Nadelhoffer, K.J.; Martin, M.E.; McDowell, W.H.; Melillo, J.M.; Steudler, P. 2004. Ecosystem response to 15 years of chronic nitrogen additions at the Harvard Forest LTER, Massachusetts, USA. Forest Ecology and Management. 196: 7-28.

McNulty, S.G.; Boggs, J.L.; Aber, J.D.; Rustad, L.; Magill, A. 2005. Red spruce ecosystem level changes following 14 years of chronic $\mathrm{N}$ fertilization. Forest Ecology and Management. 219: 279-291.

National Atmospheric Deposition Program. 2008. National Atmospheric Deposition Program 2007 Annual Summary. NADP Data Report 2008-01. Illinois State Water Survey, University of Illinois at Urbana-Champaign, Champaign, IL.

Peterjohn, W.T.; Foster, C.J.; Christ, M.J.; Adams, M.B. 1999. Patterns of nitrogen availability within a forested watershed exhibiting symptoms of nitrogen saturation. Forest Ecology and Management. 119: 247-257. 
Piatek, K.P.; Munasinghe, P.; Peterjohn, W.T.; Adams, M.B.; Cumming, J.R. 2009. Oak contribution to litter nutrient dynamics in an Appalachian forest receiving elevated $\mathrm{N}$ and dolomite. Canadian Journal of Forest Research: 39: 936-944.

SAS Institute Inc. 2002. SAS User's Guide: Statistics. Version 9.1. SAS Institute Inc., Cary, NC.

Schuler, J.L.; Robison, D.L. 2008. The effects of intensive management on the leaf characteristics and growth phenology of young yellow-poplar stems. Forest Ecology and Management. 255: 787-796.

Sherman, J.; Fernandez, I.J.; Norton, S.A.; Ohno, T.; Rustad, L.E. 2006. Soil aluminum, iron, and phosphorus dynamics in response to long-term experimental nitrogen and sulfur additions at the Bear Brook Watershed in Maine, USA. Environmental Monitoring and Assessment. 121: 421-429.

Tepp, J.S. 1995. Effects of soil ammonium sulfate applications on tree-ring chemistry in three diffuse-porous Appalachian hardwood species. M.S. Thesis. The Pennsylvania State University. 115 p.

Tomlinson, G.H. 2003. Acid deposition, nutrient leaching and forest growth. Biogeochemistry. 65: 51-81. 
Wallace, Z.P.; Lovett, G.M.; Hart, J.E.; Machona, B. 2007. Effects of nitrogen saturation on tree growth and death in a mixed-oak forest. Forest Ecology and Management. 243: 210-218.

Wallenstein, M.D.; Peterjohn, W.T.; Schlesinger, W.H. 2006. N fertilization effects on denitrification and $\mathrm{N}$ cycling in an aggrading forest. Ecological Applications. 16: 21682176.

Waring, F.H.; Running, S.W. 1998. Forest Ecosystems: analysis at multiple scales. San Diego: Academic Press. 370 p.

Whittaker, R.H.; Likens, G.E.; Bormann, F.H.; Eaton, J.S.; Siccama, T.G. 1979. The Hubbard Brook ecosystem study: forest nutrient cycling and element behavior. Ecology. 60: 203-220.

Wilmot, T.R.; Ellsworth, D.S.; Tyree, M.T. 1996. Base cation fertilization and liming effects on nutrition and growth of Vermont sugar maple stands. Forest Ecology and Management. 84: 123-134. 
Table 3. P-values associated with the effects of block, treatment (trt), and species (spp) on macronutrient concentration (\%) and content $\left(\mathrm{kg}^{\mathrm{k}} \mathrm{ha}^{-1}\right)$ in aboveground woody biomass at the LTSP site. N/A denotes data not available. ${ }^{2}$

\begin{tabular}{|c|c|c|c|c|c|c|c|c|c|c|c|c|c|c|}
\hline & \multicolumn{2}{|r|}{$\mathrm{C}$} & \multicolumn{2}{|r|}{$\mathrm{N}$} & \multicolumn{2}{|r|}{$S$} & \multicolumn{2}{|c|}{$\mathrm{P}$} & \multicolumn{2}{|c|}{ K } & \multicolumn{2}{|c|}{$\mathrm{Ca}$} & \multicolumn{2}{|c|}{$\mathrm{Mg}$} \\
\hline & $\%$ & $\mathrm{~kg} \mathrm{ha}^{-1}$ & $\%$ & $\mathrm{~kg} \mathrm{ha}^{-1}$ & $\%$ & $\mathrm{~kg} \mathrm{ha}^{-1}$ & $\%$ & $\mathrm{~kg} \mathrm{ha}^{-1}$ & $\%$ & $\mathrm{~kg} \mathrm{ha}^{-1}$ & $\%$ & $\mathrm{~kg} \mathrm{ha}^{-1}$ & $\%$ & $\mathrm{~kg} \mathrm{ha}^{-1}$ \\
\hline Block & $\mathrm{n} / \mathrm{a}$ & 0.82 & $\mathrm{n} / \mathrm{a}$ & 0.85 & $\mathrm{n} / \mathrm{a}$ & 0.94 & $\mathrm{n} / \mathrm{a}$ & 0.94 & $\mathrm{n} / \mathrm{a}$ & 0.96 & $\mathrm{n} / \mathrm{a}$ & 0.96 & $\mathrm{n} / \mathrm{a}$ & 0.90 \\
\hline Trt & $\mathrm{n} / \mathrm{a}$ & 0.39 & 0.97 & 0.66 & 0.83 & 0.58 & 0.83 & 0.58 & 0.73 & 0.70 & 0.60 & 0.68 & 0.67 & 0.58 \\
\hline Spp & $\mathrm{n} / \mathrm{a}$ & $<0.00$ & $\mathrm{n} / \mathrm{a}$ & $<0.00$ & $\mathrm{n} / \mathrm{a}$ & $<0.00$ & $\mathrm{n} / \mathrm{a}$ & $<0.00$ & $\mathrm{n} / \mathrm{a}$ & $<0.00$ & $\mathrm{n} / \mathrm{a}$ & $<0.00$ & $\mathrm{n} / \mathrm{a}$ & $<0.00$ \\
\hline Trt * spp & $\mathrm{n} / \mathrm{a}$ & 0.34 & $\mathrm{n} / \mathrm{a}$ & 0.36 & $\mathrm{n} / \mathrm{a}$ & 0.41 & $\mathrm{n} / \mathrm{a}$ & 0.41 & $\mathrm{n} / \mathrm{a}$ & 0.39 & $\mathrm{n} / \mathrm{a}$ & 0.35 & $\mathrm{n} / \mathrm{a}$ & 0.38 \\
\hline
\end{tabular}

\footnotetext{
${ }^{2}$ Nutrient content by block, trt, spp, and trt*spp was the product of the appropriate biomass and the average of all tree species' nutrient concentrations by trt.
} 
Table 4. P-values associated with the effects of block, treatment (trt), and species (spp) on micronutrient concentration (ppm) and content $\left(\mathrm{kg} \mathrm{ha}^{-1}\right)$ in aboveground woody biomass at the LTSP site. N/A denotes data not available. ${ }^{3}$

\begin{tabular}{|c|c|c|c|c|c|c|c|c|c|c|}
\hline & \multicolumn{2}{|c|}{$\mathrm{Mn}$} & \multicolumn{2}{|c|}{$\mathrm{Zn}$} & \multicolumn{2}{|c|}{$\mathrm{Fe}$} & \multicolumn{2}{|c|}{ B } & \multicolumn{2}{|c|}{$\mathrm{Cu}$} \\
\hline & $\mathrm{ppm}$ & $\mathrm{kg} \mathrm{ha}^{-1}$ & ppm & $\mathrm{kg} \mathrm{ha}^{-1}$ & $\mathrm{ppm}$ & $\mathrm{kg} \mathrm{ha}^{-1}$ & $\mathrm{ppm}$ & $\mathrm{kg} \mathrm{ha}^{-1}$ & $\mathrm{ppm}$ & $\mathrm{kg} \mathrm{ha}^{-1}$ \\
\hline Block & $\mathrm{n} / \mathrm{a}$ & 0.89 & $\mathrm{n} / \mathrm{a}$ & 0.92 & $\mathrm{n} / \mathrm{a}$ & 0.84 & $\mathrm{n} / \mathrm{a}$ & 0.87 & $\mathrm{n} / \mathrm{a}$ & 0.96 \\
\hline Trt & 0.81 & 0.06 & 0.98 & 0.01 & 0.50 & 0.50 & 0.75 & 0.45 & 0.6 & 0.69 \\
\hline Spp & $\mathrm{n} / \mathrm{a}$ & $<0.00$ & $\mathrm{n} / \mathrm{a}$ & $<0.00$ & $\mathrm{n} / \mathrm{a}$ & $<0.00$ & $\mathrm{n} / \mathrm{a}$ & $<0.00$ & $\mathrm{n} / \mathrm{a}$ & $<0.00$ \\
\hline Trt $*$ spp & $\mathrm{n} / \mathrm{a}$ & 0.21 & $\mathrm{n} / \mathrm{a}$ & 0.06 & $\mathrm{n} / \mathrm{a}$ & 0.36 & $\mathrm{n} / \mathrm{a}$ & 0.36 & $\mathrm{n} / \mathrm{a}$ & 0.35 \\
\hline
\end{tabular}

\footnotetext{
${ }^{3}$ Nutrient content by block, trt, spp, and trt*spp was the product of the appropriate biomass and the average of all tree species' nutrient concentrations by trt.
} 


\begin{tabular}{|c|c|c|c|c|}
\hline Element & & WT & $\mathrm{WT}+\mathrm{NS}$ & $\mathrm{WT}+\mathrm{NS}+\mathrm{CA}$ \\
\hline \multicolumn{5}{|l|}{$\mathrm{N}(\%)$} \\
\hline & $\mathrm{BC}$ & 0.25 & 0.24 & 0.24 \\
\hline & NRO & 0.30 & 0.27 & 0.25 \\
\hline & $\mathrm{PC}$ & 0.18 & 0.22 & 0.19 \\
\hline & $\mathrm{RM}$ & 0.23 & 0.25 & 0.22 \\
\hline & SB & 0.23 & 0.21 & 0.20 \\
\hline & YP & 0.21 & 0.22 & 0.28 \\
\hline & AVG & 0.23 & 0.23 & 0.23 \\
\hline \multicolumn{5}{|l|}{ S (\%) } \\
\hline & $\mathrm{BC}$ & 0.01 & 0.01 & 0.01 \\
\hline & NRO & 0.02 & 0.02 & 0.02 \\
\hline & $\mathrm{PC}$ & 0.01 & 0.01 & 0.01 \\
\hline & $\mathrm{RM}$ & 0.02 & 0.02 & 0.02 \\
\hline & SB & 0.01 & 0.01 & 0.01 \\
\hline & YP & 0.01 & 0.02 & 0.02 \\
\hline & AVG & 0.01 & 0.02 & 0.02 \\
\hline \multirow[t]{7}{*}{$\mathrm{P}(\%)$} & $\mathrm{BC}$ & 0.01 & 0.02 & 0.01 \\
\hline & NRO & 0.02 & 0.01 & 0.02 \\
\hline & $\mathrm{PC}$ & 0.01 & 0.01 & 0.01 \\
\hline & $\mathrm{RM}$ & 0.02 & 0.02 & 0.02 \\
\hline & SB & 0.01 & 0.01 & 0.01 \\
\hline & YP & 0.02 & 0.01 & 0.02 \\
\hline & AVG & 0.02 & 0.01 & 0.02 \\
\hline \multicolumn{5}{|l|}{$\mathrm{K}(\%)$} \\
\hline & $\mathrm{BC}$ & 0.09 & 0.09 & 0.08 \\
\hline & NRO & 0.15 & 0.11 & 0.17 \\
\hline & $\mathrm{PC}$ & 0.09 & 0.07 & 0.07 \\
\hline & $\mathrm{RM}$ & 0.16 & 0.11 & 0.10 \\
\hline & SB & 0.09 & 0.08 & 0.08 \\
\hline & YP & 0.17 & 0.17 & 0.18 \\
\hline & AVG & 0.12 & 0.11 & 0.11 \\
\hline
\end{tabular}

\begin{tabular}{|c|c|c|c|c|}
\hline Element & & WT & WT+NS & $\mathrm{WT}+\mathrm{NS}+\mathrm{CA}$ \\
\hline \multicolumn{5}{|l|}{$\mathrm{Ca}(\%)$} \\
\hline & $\mathrm{BC}$ & 0.14 & 0.16 & 0.16 \\
\hline & NRO & 0.34 & 0.26 & 0.21 \\
\hline & $\mathrm{PC}$ & 0.12 & 0.12 & 0.11 \\
\hline & $\mathrm{RM}$ & 0.36 & 0.23 & 0.21 \\
\hline & SB & 0.13 & 0.12 & 0.11 \\
\hline & YP & 0.26 & 0.23 & 0.28 \\
\hline & AVG & 0.22 & 0.19 & 0.18 \\
\hline \multicolumn{5}{|l|}{$\operatorname{Mg}(\%)$} \\
\hline & $\mathrm{BC}$ & 0.02 & 0.02 & 0.02 \\
\hline & NRO & 0.02 & 0.01 & 0.02 \\
\hline & PC & 0.02 & 0.02 & 0.02 \\
\hline & RM & 0.02 & 0.02 & 0.02 \\
\hline & SB & 0.02 & 0.02 & 0.02 \\
\hline & YP & 0.03 & 0.03 & 0.04 \\
\hline & AVG & 0.02 & 0.02 & 0.02 \\
\hline \multicolumn{5}{|l|}{$\operatorname{Mn}(\%)$} \\
\hline & $\mathrm{BC}$ & 0.02 & 0.02 & 0.02 \\
\hline & NRO & 0.03 & 0.02 & 0.02 \\
\hline & PC & 0.01 & 0.01 & 0.01 \\
\hline & RM & 0.05 & 0.04 & 0.04 \\
\hline & SB & 0.03 & 0.03 & 0.03 \\
\hline & YP & 0.04 & 0.03 & 0.02 \\
\hline & AVG & 0.03 & 0.03 & 0.02 \\
\hline \multicolumn{5}{|l|}{$\mathrm{Zn}(\mathrm{ppm})$} \\
\hline & $\mathrm{BC}$ & 3.00 & 2.00 & 1.00 \\
\hline & NRO & 4.00 & 1.00 & 2.00 \\
\hline & PC & 3.00 & 5.00 & 3.00 \\
\hline & $\mathrm{RM}$ & 9.00 & 10.00 & 9.00 \\
\hline & SB & 39.00 & 39.00 & 36.00 \\
\hline & YP & 17.00 & 4.00 & 6.00 \\
\hline & AVG & 12.50 & 10.17 & 9.50 \\
\hline
\end{tabular}

\begin{tabular}{llccc}
\hline Element & & WT & WT+NS & WT+NS+CA \\
\hline Fe (ppm) & & & & \\
& BC & 14.50 & 24.00 & 15.00 \\
& NRO & 17.00 & 16.00 & 18.00 \\
& PC & 15.00 & 20.00 & 15.00 \\
& RM & 13.50 & 14.00 & 20.00 \\
& SB & 16.00 & 9.00 & 22.00 \\
& YP & 17.00 & 25.00 & 17.00 \\
& AVG $(\mathrm{ppm})$ & 12.50 & 18.00 & 17.83 \\
& & & & \\
& BC & 3.85 & 4.00 & 3.40 \\
& NRO & 5.50 & 4.50 & 4.80 \\
& PC & 3.60 & 3.75 & 3.55 \\
& RM & 5.50 & 4.40 & 4.80 \\
& SB & 2.60 & 2.60 & 2.40 \\
& YP & 4.50 & 3.90 & 4.70 \\
& AVG & 4.26 & 3.86 & 3.94 \\
& & & & \\
Cu (ppm) & BC & 1.40 & 1.00 & 1.10 \\
& NRO & 1.50 & 1.60 & 1.50 \\
& PC & 1.00 & 0.90 & 0.95 \\
& RM & 1.60 & 1.20 & 1.10 \\
& SB & 1.80 & 1.50 & 1.60 \\
& YP & 2.10 & 1.80 & 2.20 \\
& AVG & 1.57 & 1.33 & 1.41 \\
\hline & & & &
\end{tabular}

Table 5. (Above) Nutrient concentrations by tree species and treatment; p-values associated with treatment are in Table 1.

Tree species are: PC (pin cherry), YP

(yellow-poplar), BC (black cherry), SB

(sweet birch), RM (red maple) and NRO

(northern red oak). The average for all tree species is denoted as AVG. 
Table 6. Total aboveground wood biomass in $\mathrm{kg} \mathrm{ha}^{-1}$ and content for macro- and micronutrients (kg $\mathrm{ha}^{-1}$ ) by treatment, with associated p-values. Carbon content is $50 \%$ of total biomass. Treatments are unfertilized whole tree harvest (WT), whole tree harvest plus annual nitrogen and sulfur additions (WT+NS), and whole tree harvest plus nitrogen, sulfur, and dolomitic lime (WT+NS+CA).

\begin{tabular}{lrrrr}
\hline & \multicolumn{3}{c}{ Treatments } & \\
\cline { 2 - 4 } & WT & WT+NS & WT+NS+CA & p \\
\hline Total & & & & \\
biomass & $46,654.0$ & $54,505.0$ & $51,944.0$ & 0.39 \\
\hline & & & & \\
$\mathrm{C}$ & $23,326.8$ & $27,252.3$ & $25,971.4$ & 0.39 \\
$\mathrm{Ca}$ & 65.8 & 72.5 & 73.7 & 0.68 \\
$\mathrm{~K}$ & 42.2 & 46.2 & 47.2 & 0.70 \\
$\mathrm{Mg}$ & 9.7 & 11.0 & 10.8 & 0.58 \\
$\mathrm{~N}$ & 95.4 & 107.7 & 103.9 & 0.66 \\
$\mathrm{P}$ & 5.1 & 5.8 & 5.8 & 0.58 \\
$\mathrm{~S}$ & 5.1 & 5.8 & 5.8 & 0.58 \\
$\mathrm{~B}$ & 0.2 & 0.2 & 0.2 & 0.45 \\
$\mathrm{Cu}$ & 0.0 & 0.1 & 0.1 & 0.69 \\
$\mathrm{Fe}$ & 0.8 & 0.9 & 0.9 & 0.50 \\
$\mathrm{Mn}$ & 6.5 & 5.9 & 6.2 & 0.06 \\
$\mathrm{Zn}$ & 0.4 & 0.3 & 0.3 & 0.01 \\
\hline
\end{tabular}


Table 7. Aboveground wood biomass $\left(\mathrm{kg} \mathrm{ha}^{-1}\right)$ according to the most abundant species and their totals for each treatment, with associated p-values. Treatments are unfertilized whole tree harvest (WT), whole tree harvest plus annual nitrogen and sulfur additions (WT+NS), and whole tree harvest plus nitrogen, sulfur, and dolomitic lime (WT+NS+CA). Significant differences are indicated by different letters in the same row.

\begin{tabular}{|c|c|c|c|c|c|c|c|}
\hline Species & WT & & $\mathrm{WT}+\mathrm{NS}$ & & $\mathrm{WT}+\mathrm{NS}+\mathrm{CA}$ & & $\mathrm{p}$ \\
\hline Pin & 29,620 & $\mathrm{~b}$ & 44,530 & $\mathrm{a}$ & 42,380 & $\mathrm{a}$ & 0.03 \\
\hline F. magnolia & 14,940 & & 6,560 & & 0 & & 0.62 \\
\hline Black cherry & 6,970 & & 5,170 & & 2,560 & & 0.51 \\
\hline Cucumber & 1,340 & $\mathrm{~b}$ & 1,860 & $\mathrm{~b}$ & 11,300 & $\mathrm{~b}$ & 0.10 \\
\hline Yellow-poplar & 4,810 & & 1,400 & & 7,500 & & 0.28 \\
\hline Red maple & 3,700 & & 6,620 & & 3,350 & & 0.31 \\
\hline Sweet birch & 5,550 & u & 3,210 & $a b$ & 2,720 & $\mathrm{~b}$ & 0.05 \\
\hline
\end{tabular}




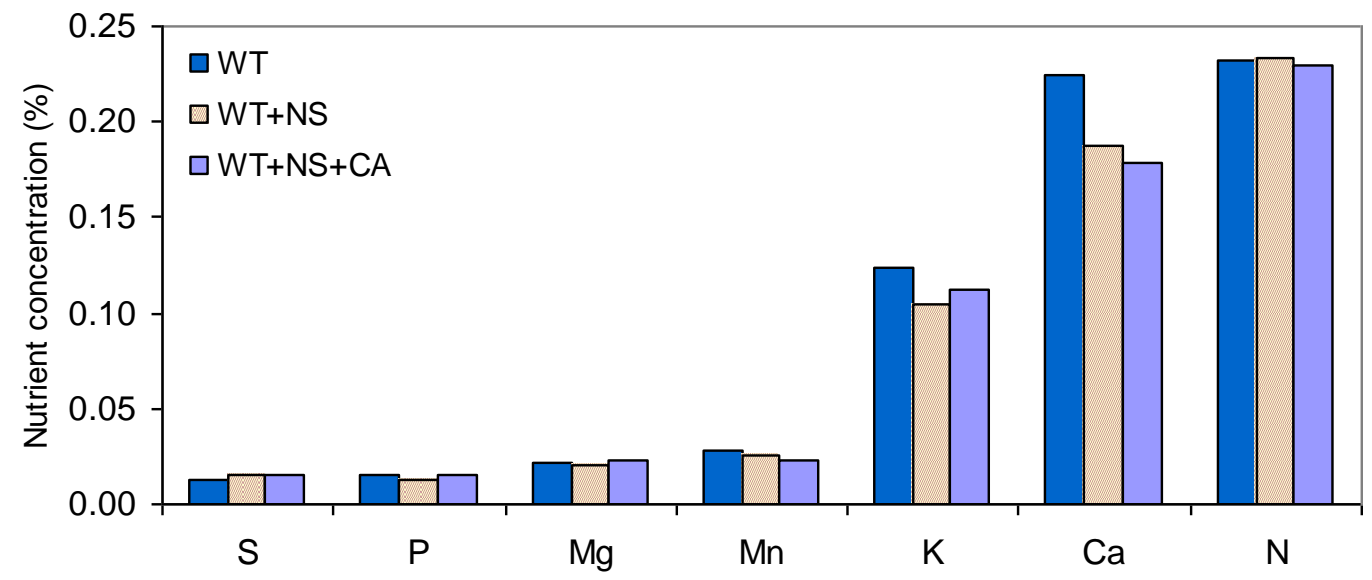

Figure 4. Average wood nutrient concentrations by treatment. Treatments are unfertilized whole tree harvest (WT), whole tree harvest plus annual nitrogen and sulfur additions (WT+NS), and whole tree harvest plus nitrogen, sulfur, and dolomitic lime (WT+NS+CA).

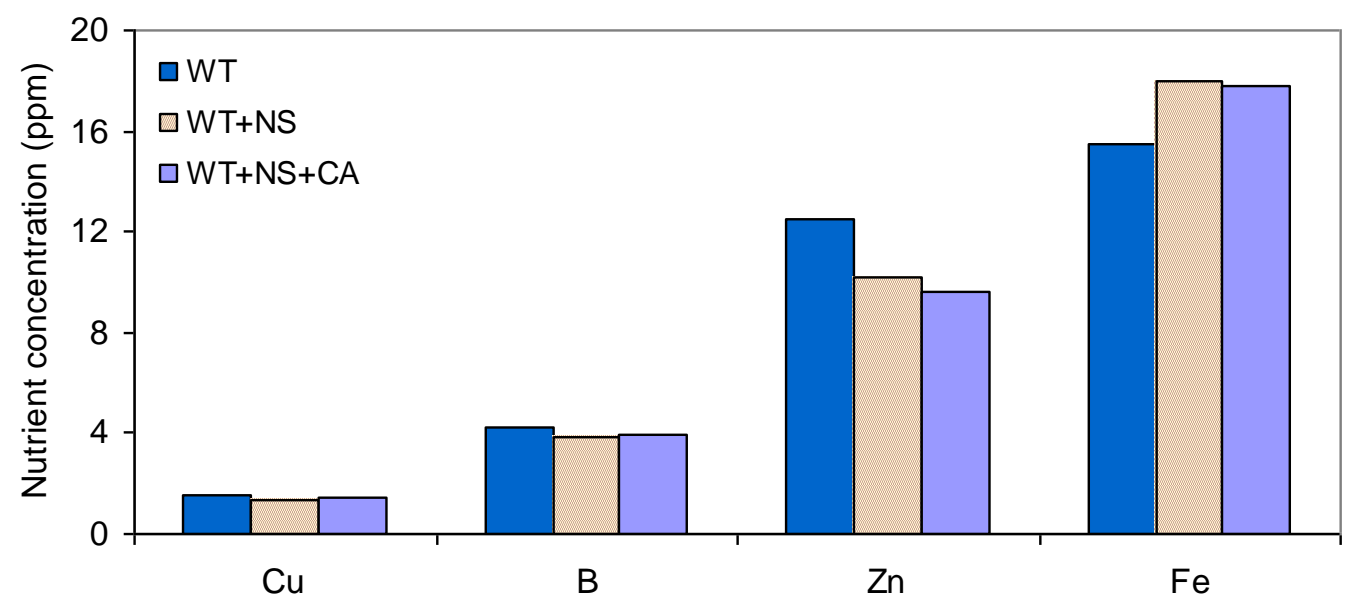

Figure 5. Average wood nutrient concentrations by treatment. Treatments are unfertilized whole tree harvest (WT), whole tree harvest plus annual nitrogen and sulfur additions (WT+NS), and whole tree harvest plus nitrogen, sulfur, and dolomitic lime (WT+NS+CA). 


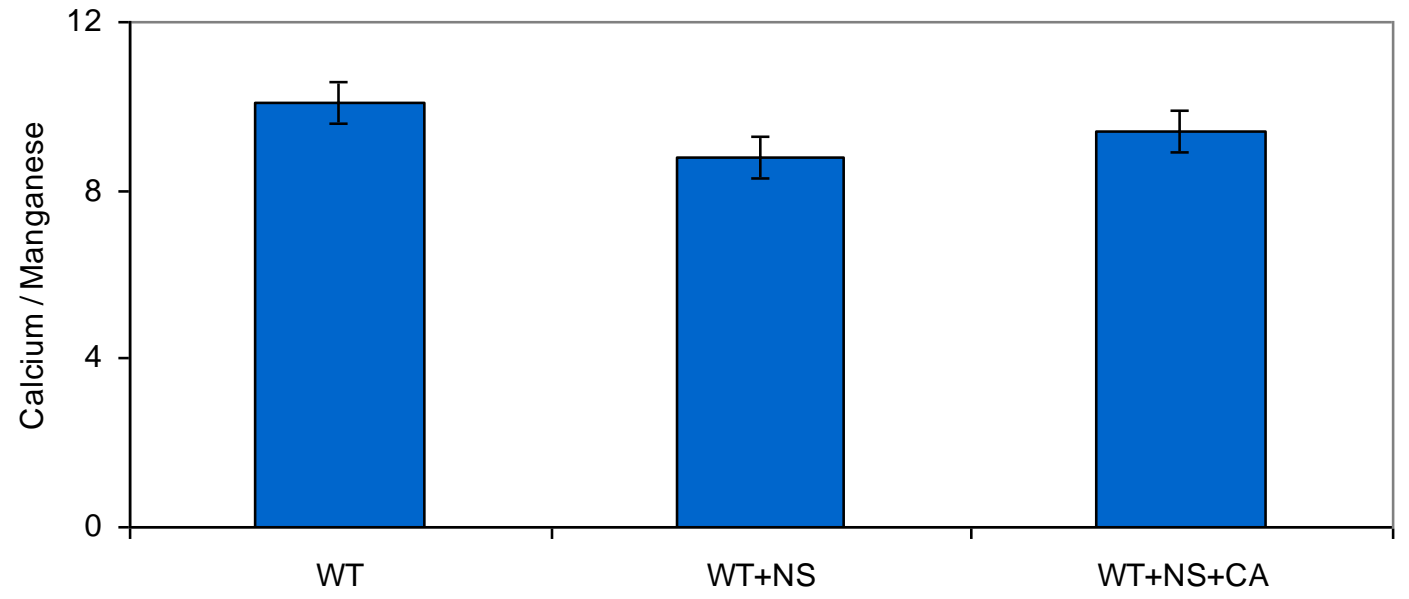

Figure 6. Wood tissue calcium to manganese concentration ratios by treatment. Treatments are unfertilized whole tree harvest (WT), whole tree harvest plus annual nitrogen and sulfur additions (WT+NS), and whole tree harvest plus nitrogen, sulfur, and dolomitic lime (WT+NS+CA).

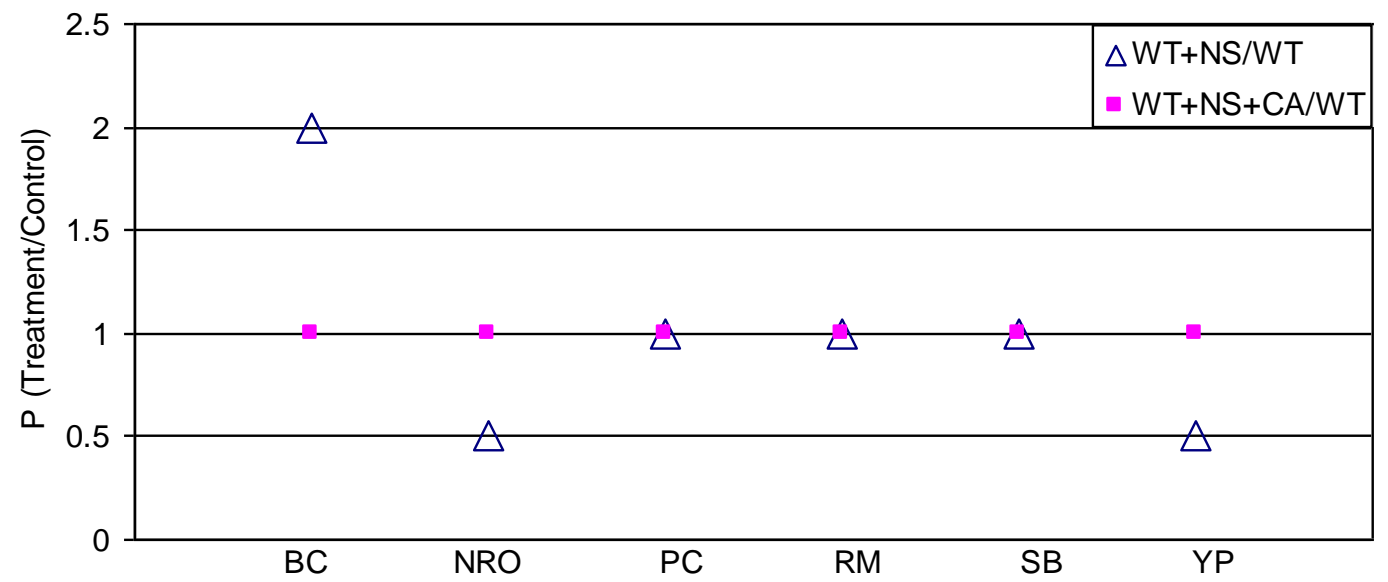

Figure 7. Tree species phosphorous wood concentrations as a comparison between treated and control plots. Control plots are unfertilized whole tree harvest (WT); treatments are whole tree harvest plus annual nitrogen and sulfur additions (WT+NS) and whole tree harvest plus nitrogen, sulfur, and dolomitic lime (WT+NS+CA). Tree species are denoted as PC (pin cherry), YP (yellowpoplar), BC (black cherry), SB (sweet birch), RM (red maple) and NRO (northern red oak). 


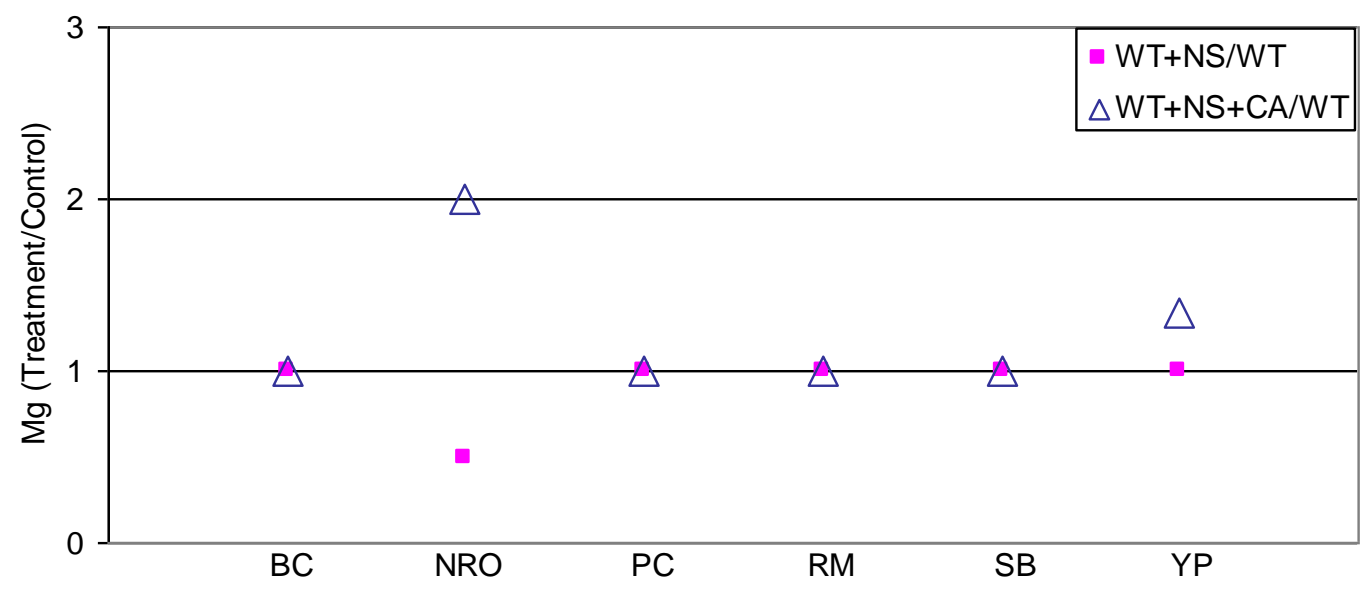

Figure 8. Tree species magnesium wood concentrations as a comparison between treated and control plots. Control plots are unfertilized whole tree harvest (WT); treatments are whole tree harvest plus annual nitrogen and sulfur additions (WT+NS) and whole tree harvest plus nitrogen, sulfur, and dolomitic lime (WT+NS+CA). Tree species are denoted as PC (pin cherry), YP (yellow-poplar), BC (black cherry), SB (sweet birch), RM (red maple) and NRO (northern red oak). 


\section{Chapter V: Are fine roots affected by ammonium sulfate and dolomitic lime amendments in a young deciduous forest?}

\subsection{Abstract}

This study was implemented to understand the effects of simulated acidic deposition and additions of dolomitic lime on belowground fine root $(\leq 2 \mathrm{~mm})$ biomass and nutrient levels in a twelve-year-old Appalachian hardwood forest. Three treatments in three blocks were compared: whole tree harvest (WT), whole tree harvest plus annual nitrogen and sulfur (WT+NS), and whole tree harvest plus annual nitrogen, sulfur, and dolomitic lime (WT+NS+CA). Differences in fine root biomass and nutrient content were observed in these plots due to significant block*treatment interactions (ANOVA: $F=5.27, p<0.05$, $\mathrm{n}=9$ ). Fine root biomass was significantly greater in the WT+NS treatment in block III $\left(7,761.1 \mathrm{~kg} \mathrm{ha}^{-1} \pm 1,202.8\right)$ compared to both the WT $\left(3,441 \mathrm{~kg} \mathrm{ha}^{-1} \pm 1,267.8\right)$ and WT+NS $\left(4,212 \mathrm{~kg} \mathrm{ha}^{-1} \pm 1,267.8\right)$ treatments in block II, and the WT $\left(4,680 \mathrm{~kg} \mathrm{ha}^{-1} \pm\right.$ $1,202.8)$ and $\mathrm{WT}+\mathrm{NS}+\mathrm{CA}\left(3,239 \mathrm{~kg} \mathrm{ha}^{-1} \pm 1,202.8\right)$ treatments in block IV. Fine root nitrogen and phosphorus content was significantly lower in the WT and WT+NS treatments in block II, and the WT and WT+NS+CA treatments in block IV compared to the WT+NS treatment in block III. The variety of responses in fine root biomass and nutrient content among the treatments and blocks indicate differences in soil nutrient availability within these plots. Tendency toward higher fine root biomass and nutrient content in the WT+NS treatment, especially in block III, may be a result of chronic acid deposition. Our findings suggest that increased levels of $\mathrm{N}$ and $\mathrm{S}$ deposition can alter the production and nutrient content of fine root biomass in the early stages of forest 
succession. Dolomitic lime did not appear to affect fine root biomass and content by stand age twelve. 


\subsection{Introduction}

Fine roots $(\leq 2 \mathrm{~mm})$ play an important role in forest ecosystems in regard to their ability to take up water and necessary nutrients, which will ultimately influence aboveground biomass production. In many cases, belowground biomass production is equal to or greater than primary production allocated to leaves (Nadelhoffer and Raich 1992, Cairns et al. 1997, Jackson et al. 1997). Net primary production of a forest depends on, among other things, nutrient availability. Atmospheric deposition can impact soil nutrient availability by changing $\mathrm{pH}$ and through increased nutrient leaching losses, and fine root biomass may respond to these nutrient conditions in the soil. Therefore, it is important to understand how fine roots are affected by chronic acid deposition. The potential for acidic deposition to directly or indirectly affect fine root biomass has implications for aboveground productivity and for carbon (C) storage.

Results from experiments that evaluate the impacts of acidic deposition on fine root biomass and productivity are varied. When applied experimentally, nitrogen $(\mathrm{N})$ additions may also relieve soil $\mathrm{N}$ limitations and therefore stimulate fine root production (Magill et al. 1997, Pregitzer et al. 2000). Alternatively, fine root biomass may be negatively correlated with higher $\mathrm{N}$ availability from deposition and soil mineralization (Nadelhoffer 1985, 2000, Aber 1989). Chronic acid deposition may also lead to increased leaching losses of cations from the soil (Johnson 1992, Adams et al. 1997, Tomlinson 2003, Sherman et al. 2006) and lead to N saturation (inputs of N exceed biological demand), which may also negatively affect fine root biomass (Aber et al. 1989) and 
chemistry (Persson et al. 1995). For instance, an extensive review of fertilizer studies in Sweden indicated that aluminum toxicity, caused by cation depletion and high nitrogen to cation ratios, reduced fine root growth and mycorrhizal development and increased sensitivities of roots to drought, wind-break and nutrient stress (Persson et al. 1995).

Decreases in soil $\mathrm{pH}$ due to $\mathrm{N}$ deposition have been shown to affect the ability of mycorrhizal fungi to acquire nutrients from the soil (Dighton and Skeffington 1987, Boxman et al. 1998). Also, elevated soil aluminum (Al), which can be caused by chronic acid deposition, is toxic to specific ectomycorrhizal species (Thompson and Medve 1984). High soil Al levels can negatively affect root uptake of calcium (Ca), magnesium $(\mathrm{Mg})$, and phosphorus (P), and inhibit root absorption and elongation (Lambers et al. 2006). The Long-Term Soil Productivity (LTSP) site at the Fernow Experimental Forest (FEF) showed significantly lower $\mathrm{pH}$ in ammonium sulfate treated sites (Wallenstein et al. 2006), which may decrease the ability of fine roots to sequester cations and P. Long term implications of lower fine root nutrient acquisition may include reductions in aboveground productivity. Dolomitic lime additions, however, may have the potential to ameliorate the affects of acidic deposition by perhaps improving the ectomycorrhizal status of roots and nutrient uptake, as seen in a liming experiment by Børja and Nilsen (2009).

Because of the variety of reported responses of fine roots to acidic deposition and the importance of linking above- and belowground production, this study was developed to estimate belowground biomass up to a $30 \mathrm{~cm}$ soil depth in a young, aggrading hardwood 
stand. The LTSP site in the FEF served as the site location; the area experiences some of the highest rates of $\mathrm{N}$ deposition in the northeastern United States (Adams et al. 2000). Effects of treatments of twice ambient ammonium sulfate additions alone and in combination with dolomitic lime on fine root productivity and nutrient content were evaluated. Nutrient concentrations in bolewood, including C, N, P, Ca, Mg, sulfur (S), and potassium $(\mathrm{K})$, were determined as each play an important role in fine root structure, growth, and vitality (Lambers et al. 2006). Aboveground wood biomass has already been estimated in the LTSP site; therefore this study will allow us to make connections between above- and belowground wood biomass production, nutrient status, and also estimate the amount of $\mathrm{C}$ stored in these components.

\subsection{Study site}

We conducted the study at the Long-Term Soil Productivity (LTSP) sites on Fork Mountain in the Fernow Experimental Forest near Parsons, West Virginia (39 $03^{\prime} \mathrm{N}$, $7^{\circ} 29^{\prime} \mathrm{W}$ ). Precipitation averages $146 \mathrm{~cm}$ annually (Wallenstein et al. 2006) and average bulk precipitation input is $11.3 \mathrm{~kg} \mathrm{ha}^{-1} \cdot \mathrm{yr}^{-1}$ for inorganic $\mathrm{N}$ (Adams et al. 1997). Dominant soil type is a Calvin channery silt loam derived from acidic sandstone and shale of the Upper Devonian Hampshire formation (Kochenderfer 2006). See Adams et al. (2004) for complete pre-treatment site characterizations.

In 1996, four blocks were established along a slope gradient ranging from $798 \mathrm{~m}$ to 847 $\mathrm{m}$ in elevation. Four treatments were imposed in a randomized complete block design, 
including an unharvested and unfertilized control, unfertilized whole-tree harvested control (WT), whole-tree harvested ammonium sulfate additions (WT+NS), and wholetree harvested ammonium sulfate additions plus dolomitic lime (WT+NS+CA). Individual growth plots measure 0.2 ha in addition to a $7.6 \mathrm{~m}$ wide buffer strip on each side; plots are adjacent to each other within a block. The rate of addition for the WT+NS treatment was two times the ambient $\mathrm{N}$ and $\mathrm{S}$ throughfall deposition. Ambient deposition in early 1980 was $\sim 15 \mathrm{~kg} \mathrm{~N} \mathrm{ha}^{-1} \cdot \mathrm{yr}^{-1}$ and $17 \mathrm{~kg} \mathrm{~S} \mathrm{ha}^{-1} \cdot \mathrm{yr}^{-1}$ (Helvey and Kunkle 1986); therefore $36 \mathrm{~kg} \mathrm{~N} \mathrm{ha}^{-1} \cdot \mathrm{yr}^{-1}$ and $40 \mathrm{~kg} \mathrm{~S} \mathrm{ha}^{-1} \cdot \mathrm{yr}^{-1}$ are added in fertilizer. The $\mathrm{WT}+\mathrm{NS}+\mathrm{CA}$ plots received two times ambient $\mathrm{N}$ and $\mathrm{S}$ fertilizer as well as $22.5 \mathrm{~kg} \mathrm{Ca}$ $\mathrm{ha}^{-1} \cdot \mathrm{yr}^{-1}$ plus $11.6 \mathrm{~kg} \mathrm{Mg} \mathrm{ha}{ }^{-1} \cdot \mathrm{yr}^{-1}$, which is equivalent to two times the rate of export of $\mathrm{Ca}$ and $\mathrm{Mg}$ to stream water (Wallenstein et al. 2006). Pre-treatment mean soil $\mathrm{pH}$ was 4.24 (Adams et al. 2004). Five years after treatment, soil pH was 2.96, 3.22, and 3.41 in the $\mathrm{WT}+\mathrm{NS}, \mathrm{WT}$, and $\mathrm{WT}+\mathrm{NS}+\mathrm{CA}$ treatments, respectively (Wallenstein and others 2006).

\subsection{Methods}

\subsubsection{Root collection}

In August 2008, fine roots were sampled within three of the four blocks. High content of coarse fragments in block I prevented sampling of roots. Soil cores $3.8 \mathrm{~cm}$ in diameter and $30.5 \mathrm{~cm}$ in length were used to collect ten samples within each plot in each treatment, for a total of 90 samples. Samples were taken from random locations in the growth plots 
and buffer strips. Once a sample was retrieved, it was placed in a plastic bag and upon arrival at the lab; all samples were refrigerated until roots were separated from the soil.

\subsubsection{Fine root processing}

Soil samples were passed through a $2 \mathrm{~mm}$ sieve; roots that did not pass through but were $\leq 2 \mathrm{~mm}$ in diameter were retrieved. The soil that went through the $2 \mathrm{~mm}$ sieve was then placed on 125-250 $\mu \mathrm{m}$ sieves in small portions and was sorted through until all live and dead roots were gathered. Roots of herbaceous plants, recognized by their white, bulbous roots, were not included.

Soil was washed from the roots by placing the entire sample in a petri dish and dousing the roots with deionized water. Soil clumps were gently broken apart with tweezers to keep the fine roots intact. All roots were rinsed a final time before being oven-dried at $70^{\circ} \mathrm{C}$ and weighed to the nearest 0.01 gram. Fine root biomass was calculated as an average of fine root weight by treatment and block. The mass of the sample was divided by the area of the soil core $\left(11.3 \mathrm{~cm}^{2}\right)$ and expanded to $\mathrm{kg} \mathrm{ha}^{-1}$.

\subsubsection{Fine root nutrient concentrations and content}

The ten replicate fine root samples per plot were combined, finely ground, and two subsamples from each plot were shipped to Spectrum Analytic (Washington Court House, $\mathrm{OH}$ ) for nutrient analysis. Nutrients were analyzed using microwave digestion 
and ICP emission spectroscopy for elements including: S, P, K, Mg, and Ca. Nitrogen and $\mathrm{C}$ concentrations were determined by a $\mathrm{CN}$ analyzer. At this time, only one block has been analyzed for $\mathrm{C}$ and all three blocks have been analyzed for the other nutrients. Nutrient concentrations were multiplied by fine root biomass estimates to determine nutrient content.

Fine root biomass and nutrient content were compared between treatment, block, and interaction of treatment*block using analysis of variance (ANOVA) in SAS (SAS Institute Inc., 2002). T-tests were also used to compare biomass, nutrient concentrations, and content between treatment and block. Differences were considered significant at $\mathrm{p} \leq$ 0.10 .

\subsection{Results}

\subsubsection{Fine root biomass}

Table 8 details the p-values associated with block, treatment, and block*treatment interactions for fine root biomass. Main effects (block and treatment) and the interaction between block*treatment were statistically significant. Fine root biomass was higher in the WT+NS treatment in block III $\left(7,761 \mathrm{~kg} \mathrm{ha}^{-1} \pm 1,202.8\right)$, but was only significantly

greater than the WT $\left(3,441 \mathrm{~kg} \mathrm{ha}^{-1} \pm 1,267.8\right)$ and WT+NS $\left(4,212 \mathrm{~kg} \mathrm{ha}^{-1} \pm 1,267.8\right)$ treatments in block II and WT $\left(4,680 \mathrm{~kg} \mathrm{ha}^{-1} \pm 1,202.8\right)$ and WT+NS+CA $\left(3,239 \mathrm{~kg} \mathrm{ha}^{-1}\right.$ $\pm 1,202.8$ ) treatments in block IV (Figure 9 and Table 9). As indicated in methods, block I was not sampled. 


\subsubsection{Fine root nutrient concentrations}

P-values associated with block, treatment, and block*treatment interactions for nutrient concentrations are shown in Table 8. Generally, all main effects and interactions were statistically significant except for $\mathrm{K}$, and for some treatment effects for $\mathrm{Ca}$ and $\mathrm{Mg}$. Fine root nutrient concentration data are not shown. Nitrogen fine root concentrations were significantly greater in the WT+NS+CA treatment in block III $(1.84 \% \pm 0.18)$ compared to the WT+NS treatment in block IV $(1.30 \% \pm 0.18)$. Fine root $\mathrm{P}$ concentrations were significantly higher in block II in the WT and WT+NS treatments $(0.10 \% \pm 0.003$ for both) compared to all treatments in block IV (averaged $0.08 \% \pm 0.003$ ). Calcium had greater fine root concentrations in the WT treatment in block II $(0.41 \% \pm 0.07)$ compared to the WT and WT+NS treatments in block IV $(0.21 \% \pm 0.07$ for both). Potassium fine root concentrations did not differ significantly with treatment or block*treatment interactions. Carbon concentrations were significantly different between treatments $(\mathrm{p}<0.05)$. The $\mathrm{WT}+\mathrm{NS}+\mathrm{CA}$ treatment had the highest concentration of $\mathrm{C}$ $(39.1 \% \pm 0.26)$ compared to the WT and WT+NS treatments $(37.5 \% \pm 0.29$ and $36.1 \%$ \pm 0.26 , respectively). Carbon:N ratios ranged from 25, 23, and 25 for the WT, WT+NS, and $\mathrm{WT}+\mathrm{NS}+\mathrm{CA}$ treatments, respectively, due to less $\mathrm{C}$ and greater $\mathrm{N}$ in the WT+NS treatment. 


\subsubsection{Fine root nutrient content}

Table 8 shows p-values associated with nutrient contents by treatment, block, and block*treatment interactions. Significant block*treatment interactions were detected for fine $\operatorname{root} \mathrm{N}, \mathrm{S}, \mathrm{P}, \mathrm{Ca}$, and $\mathrm{Mg}$ contents. Fine root nutrient content data are shown in Table 9. Generally, the WT+NS treatment in block III was highest for most variables because of greater fine root biomass. Carbon content in fine roots was higher in the WT+NS treatment compared to the WT treatment. Fine root K content was not significantly different between treatments or block*treatment interactions. Significantly higher fine root biomass in the WT+NS treatment in block III resulted in greater nutrient content for $\mathrm{N}, \mathrm{S}, \mathrm{P}, \mathrm{K}$, and Ca compared to the WT and WT+NS treatments in block II (Table 9 and Figures 10 through 12). Block III did not have significant differences in fine root biomass among the three treatments. Therefore, differences in nutrient content between treatments were directly affected by variations in nutrient concentrations. In block III, the WT treatment had significantly lower $\mathrm{N}$ and $\mathrm{S}$ content compared to the WT+NS treatment; the WT+NS+CA treatment had significantly lower S and P content compared to the WT+NS treatment. Similarly, block IV had significantly lower N, S, and P fine root content in the WT and WT+NS+CA treatments compared to the WT+NS treatment in block III. Magnesium was the only nutrient that showed no significant differences in nutrient content among treatments in blocks III and IV. 


\subsection{Discussion}

\subsubsection{Fine root biomass}

At an average of 3,912 $\mathrm{kg} \mathrm{ha}^{-1}$, fine root biomass in all plots at our site was lower than fine root biomass estimates from the Fernow Watershed Acidification Study $(6,667 \mathrm{~kg}$ $\mathrm{ha}^{-1}$ to $30 \mathrm{~cm}$ soil depth; Adams et al. 1995). The LTSP forest was 12 years younger than the watersheds when these measurements were taken. Fine root biomass changes substantially during forest succession (Yin et al. 1989) with large annual variation. Across a chronosequence of oak-hickory forests, fine root biomass increased from 6 to 12 years of age and then decreased from 12 to 31 years of age (Idol et al. 1998). Therefore, the LTSP forest may be still be accumulating fine root biomass, while the stand in the Fernow Watershed Acidification Study may have already peaked. However on average, in our study, the WT and WT+NS+CA treatments had less fine root biomass than the ammonium sulfate treated plots (WT+NS), while the opposite was true for the watershed study (control had twice the fine root biomass found in the treated watershed; Adams et al. 1995). The treated watershed stand, however, may have sustained greater production and turnover rates for a period of time, which may have lead to an eventual reduction in fine root biomass (Nadelhoffer 2000). Increased fine root production with a decrease in survival has been observed in acidification experiments (Majdi 1994, ClemenssonLindell and Persson 1995). The reason(s) for significantly higher fine root biomass under ammonium sulfate additions, especially in block III, will be discussed below. 
Fine root biomass is often inversely related to site fertility (Vogt et al. 1986, Haynes and Gower, 1995); with greater soil nutrient availability, fewer roots are needed for the same amount of nutrient uptake and less energy needs to be expended on root production. Therefore, greater fine root biomass in the WT+NS treatment may be a sign of decreased soil nutrient availability. The LTSP WT+NS plots have the lowest average soil $\mathrm{pH}$ (2.96) of any of the treatments (Wallenstein et al. 2006) and elevated soil acidity has been shown to decrease cation nutrient availability (Johnson 1992, Adams et al. 1997, Tomlinson 2003, Sherman et al. 2006). If cation availability is lower in these treated LTSP plots, it appears that the increased fine root biomass may compensate for lower availability of some of the nutrients due to low soil $\mathrm{pH}$. As this forest ages, greater belowground competition should accentuate the effects of increased atmospheric deposition on fine root productivity under these varying conditions of soil nutrient availability.

\subsubsection{Are above- and belowground biomass productivity related?}

At the time we made our measurements, above- and belowground productivity did not seem to be strongly affected by the acidic deposition treatments. Even though the aboveground biomass in the WT+NS treatment was higher than the WT and $\mathrm{WT}+\mathrm{NS}+\mathrm{CA}$ treatments, the difference was not significant (Chapter 1). Average fine root biomass was also greater (only significantly so in block III) in the WT+NS treatment and suggests that twice ambient ammonium sulfate additions have the potential to increase belowground productivity in this young forest. If belowground productivity increases in 
all blocks as this forest matures, it may lead to increased aboveground productivity. Above- and belowground productivity in mature forests appears to be correlated (Nadelhoffer and Raich 1992, Cairns et al. 1997, Jackson et al. 1997), therefore more time may be needed for aboveground productivity to respond to improved belowground productivity in the WT+NS treatment. Conversely, with continual ammonium sulfate additions, reductions in fine root biomass may occur (Nadelhoffer 2000) as this forest ages and could result in decreased aboveground productivity as hypothesized by the $\mathrm{N}$ saturation hypothesis (Aber et al. 1989).

\subsubsection{Fine root nutrient concentrations and content}

In addition to higher average fine root biomass, the WT+NS treatment in our study had lower fine root $\mathrm{C}$ concentrations. The WT+NS treatment at the LTSP site had the greatest C content compared to the WT and WT+NS+CA treatment and according to Hendricks et al. (1993) and Nadelhoffer (2000), greater C content tends to be allocated belowground due to greater fine root turnover in conditions of greater $\mathrm{N}$ availability. Due to the young age of the LTSP site, the ammonium sulfate treated stands have probably not significantly increased fine root turnover rates. Rather than a direct deposition effect, this is more likely due to a dilution effect from a higher mass of fine roots at the LTSP site.

Fine root $\mathrm{C}: \mathrm{N}$ ratios indicate the amount of $\mathrm{N}$ relative to $\mathrm{C}$ allocated to belowground biomass. Fine root $\mathrm{C}: \mathrm{N}$ ratio was lowest in the $\mathrm{WT}+\mathrm{NS}$ treatment and was driven by lower concentrations of $\mathrm{C}$ and higher concentrations of $\mathrm{N}$. Higher $\mathrm{N}$ concentrations were 
probably due to ammonium sulfate additions and indicate the increased ability of fine roots to store N. The same results were observed at the Harvard Forest hardwood stand after 15 years of ammonium nitrate additions; fine root $\mathrm{C}: \mathrm{N}$ ratios were significantly lower in ammonium nitrate treated plots compared to the control; their results were also driven by higher concentrations of $\mathrm{N}$ in the treated plots, but $\mathrm{C}$ did not differ between treatments (Magill et al. 2004). Fine roots in stands that received $\mathrm{N}$ amendments at the LTSP site and the Harvard Forest have the potential to retain N after the onset of simulated acidic deposition. Greater $\mathrm{N}$ content in the photosynthetic apparatus of vegetation may result in greater productivity; retention can also prevent losses of $\mathrm{N}$ to soil solution and therefore stream waters.

\subsubsection{Block differences in fine root biomass and nutrient content}

The difference in fine root biomass between blocks, in addition to treatment, may be attributed to inherent differences in site characteristics such as differences in species composition, soil chemistry, or topography. For instance, pre-treatment data indicated greater soil base cation concentrations especially in block I, which may be due to the

limestone-based gravel road $10 \mathrm{~m}$ upslope from block I (Adams et al. 2004). Even though block I was not sampled in this study, block II likely experiences higher base cation nutrient concentrations compared to the blocks down-slope. The WT+NS treatment in blocks II and III had greater fine root biomass than the other treatments in those blocks, which may be attributed to cation nutrient displacement caused by ammonium sulfate additions. Also, block III may have an exacerbated impact on fine root biomass due to a 
lower soil buffering capacity. Block IV seems to have been less affected by ammonium sulfate additions; the WT+NS and $\mathrm{WT}+\mathrm{NS}+\mathrm{CA}$ treatments may have improved soil status as fine root biomass is lower in those plots. Topography also differs at the LTSP site in that Block III is steeper compared to Block IV, which is at the bottom of the slope. Block IV may therefore be more fertile and mesic, requiring less root biomass. The variability observed between blocks at our site indicates that soil nutritional status plays a significant role in how fine root biomass responds to acidic deposition. However, the degree to which increased atmospheric deposition may affect fine root biomass must be considered with caution as treatment, block, and pre-treatment differences must be taken into account.

Differences in fine root nutrient content between blocks can also be helpful for detecting variability in soil nutrient availability across the LTSP site. For instance, the WT+NS treatment in block III demonstrated the highest fine root content of N, S, P, K, Ca, and Mg compared to the WT and WT+NS+CA treatments in block III, and was caused by significantly higher fine root biomass. Alternatively, in block II, the WT+NS+CA treatment showed the highest content for all nutrients even though fine roots in this treatment did not have the greatest biomass. Block IV exhibited the highest fine root biomass in the WT treatment, which may indicate that treatment additions improved the soil status in this block. Ammonium sulfate additions alone did not affect nutrient availability to the same extent in blocks II and IV compared to block III after 12 years of additions. Poorer nutrient status in block III compared to block II and IV has apparently 
resulted in greater allocation of energy to belowground biomass in block III, especially in the WT+NS treatment.

\subsection{Conclusions}

A significant block*treatment interaction indicated that there was a weak trend in fine root biomass between blocks or treatments; fine root biomass was significantly greater in block III in the WT+NS treatment only compared to some plots. The differences in fine root biomass and nutrient content in the LTSP site among blocks and treatments may be attributed to variations in soil base cation availability, which may be greater in block II. Average fine root biomass in the WT+NS treatment is greater than the WT and $\mathrm{WT}+\mathrm{NS}+\mathrm{CA}$ treatments by compensating for lower nutrient availability due to lower soil $\mathrm{pH}$. Lastly, the ameliorative effects of dolomitic lime on fine root biomass were not apparent, but this could be due to the high variation caused by block and treatment

effects. Regardless, these findings suggest that increased levels of $\mathrm{N}$ and $\mathrm{S}$ deposition can significantly alter the production and nutrient content of fine root biomass in the early stages of forest succession, depending on a forest's soil nutrient availability.

At this time, however, adverse effects in terms of belowground productivity and nutrient content from acidic deposition have not been realized on these stands. Because the LTSP site is only 12 years old, fine root biomass is likely still accumulating, sequestering $\mathrm{C}$, and acting as a belowground sink for $\mathrm{N}$ in all plots regardless of treatment. Yet, an overall decline in fine root biomass in the WT+NS treatment, as seen at the Fernow 
ammonium sulfate treated watershed, may be inevitable within one or two decades. Continued treatments and greater resource competition with increasing forest age will give us a better idea as to how the belowground production in this forest will ultimately affect aboveground wood productivity. Stem wood tissue analysis (Chapter 2) has already suggested that several macronutrients are limiting in the WT+NS treatment, which may negatively affect tree growth and vigor in these plots over time. Continued comparisons of above- and belowground biomass are essential to understand the impact acidic deposition has on forest productivity and therefore potential $\mathrm{C}$ sequestration in both of these pools. 


\subsection{Literature Cited}

Aber, J.D.; Nadelhoffer, K.J.; Steudler, P.; Melillo, J.M. 1989. Nitrogen saturation in northern forest ecosystems. BioScience. 39: 378-386.

Adams, M.B.; Kochenderfer, J.N.; Angradi, T.R.; Edwards, P.J. 1995. In: Gottschalk, K. W.; Fosbroke, S. L. C., ed. Proceedings, 10th Central Hardwood Forest Conference; 1995 March 5-8; Morgantown, WV: Gen. Tech. Rep. NE-197. Radnor, PA: U.S. Department of Agriculture, Forest Service, Northeastern Forest Experiment Station. 119-130.

Adams, M.B.; Angradi, T.R.; Kochenderfer, J.N. 1997. Stream water and soil solution responses to 5 years of nitrogen and sulfur additions at the Fernow Experimental Forest, West Virginia. Forest Ecology and Management. 95: 79-91.

Adams, M.B.; Burger, J.A.; Jenkins, A.B.; and Zelazny, L. 2000. Impact of harvesting and atmospheric pollution on nutrient depletion of eastern US hardwood forests. Forest Ecology and Management. 138: 301-319.

Adams, M.B.; Burger, J.; Zelazny, L.; Baumgras, J. 2004. Description of the Fork Mountain long-term soil productivity study: site characterization. Gen. Tech. Rep. NE323. Newtown Square, PA: U.S. Department of Agriculture, Forest Service, Northeastern Research Station. 40 p. 
Børja, I.; Nilsen, P. 2009. Long term effect of liming and fertilization on ectomycorrhizal colonization and tree growth in old Scots pine (Pinus sylvestris L.) stands. Plant Soil. 314: 109-119.

Boxman, A.W.; Blanck, K.; Brandrud, T.-E.; Emmett, B.A.; Gundersen, P.; Hogervorst, R.F.; Kjonaas, O.J.; Persson, H.; Timmermann, V. 1998. Vegetation and soil biota response to experimentally-changed nitrogen inputs in coniferous forest ecosystems of the NITREX project. Forest Ecology and Management. 101: 65-79.

Cairns, M.A.; Brown, S.; Helmer, E.H.; Baumgardner, G.A. 1997. Root biomass allocation in the world's upland forests. Oecologia. 111: 1-11.

Clemensson-Lindell, A.; Persson, H. 1995. Fine-root vitality in a Norway spruce stand subjected to various nutrient supplies. Plant and Soil. 168-169: 167-172.

Dighton, J.; Skeffington, R.A. 1987. Effects of artificial acid precipitation on the mycorrhizas of Scots pine seedlings. New Phytologist. 107: 191-202.

Haynes, B.E.; Gower, S.T. 1995. Belowground carbon allocation in unfertilized and fertilized red pine plantations in northern Wisconsin. Tree Physiology. 15: 317-325. 
Helvey, J.D.; Kunkle, S.H. 1986. Input-out budgets of selected nutrients on an experimental watershed near Parsons, West Virginia. Res. Paper. NE-584. Broomall, PA: U.S. Department of Agriculture, Forest Service, Northeastern Forest Experiment Station. $7 \mathrm{p}$.

Hendricks, R.L.; Nadelhoffer, K.J.; Aber, J.D. 1993. The role of fine roots in energy and nutrient cycling. Trends in Ecology and Evolution. 8: 174-178.

Idol, T.W.; Pope, P.E.; Tucker, J.; Ponder, F. Jr. 1998. The role of fine root dynamics in the $\mathrm{N}$ and $\mathrm{P}$ cycles of regenerating upland oak-hickory forests. In: Waldrop, T.A., ed. Proceedings, $9^{\text {th }}$ Biennial southern silvicultural research conference; 1997 February 2527; Clemson, SC. Gen. Tech. Rep. SRS-20. Asheville, NC: U.S. Department of Agriculture, Forest Service, Southern Research Station: 136-140.

Jackson, R.B.; Mooney, H.A.; Schulze, E.D. 1997. A global budget for fine root biomass, surface area, and nutrient contents. Proceedings of the National Academy of Sciences. 94: 7362-7366.

Johnson, D.W. 1992. Base cations. In: Johnson, D.W.; Lindberg, S.E., eds. Atmospheric deposition and forest nutrient cycling. New York: Springer-Verlag: 233-340. 
Kochenderfer, J.N. 2006. Fernow and the Appalachian hardwood region. In: Adams, M.B.; DeWalle, D.R.; Hom, J.L., eds. The Fernow watershed acidification study. Dordrecht, The Netherlands: Springer: 17-39.

Lambers, H.; Chapin III, F.S.; Pons, T.L. 2006. Plant physiological ecology. New York: Springer. $540 \mathrm{p}$.

Magill, A.H.; Aber, J.D.; Hendricks, J.J.; Bowden, R.D.; Melillo, J.M.; Steudler, P.A. 1997. Biogeochemical response of forest ecosystems to simulated chronic nitrogen deposition. Ecological Applications. 7: 402-415.

Magill, A.H.; Aber, J.D.; Currie, W.; Nadelhoffer, K.J.; Martin, M.E.; McDowell, W.H.; Melillo, J.M.; Steudler, P. 2004. Ecosystem response to 15 years of chronic nitrogen additions at the Harvard Forest LTER, Massachusetts, USA. Forest Ecology and Management. 196: 7-28.

Majdi, H. 1994. Effects of nutrient applications on fine-root dynamics and root/rhizosphere chemistry in a Norway spruce stand. Ph.D. thesis, Department of Ecology and Environmental Research, Sweden University of Agriculture Sciences. Rep. 71: $1-83$.

Nadelhoffer, K.J.; Aber, J.D.; Melillo, J.M. 1985. Fine root production in relation to net primary production along a nitrogen availability gradient in temperate forests: a new hypothesis. Ecology 66: 1377-1390. 
Nadelhoffer, K.J.; Raich, J.W. 1992. Fine root production estimates and belowground carbon allocation in forest ecosystems. Ecology. 73: 1139-1147.

Nadelhoffer, K.J. 2000. The potential effects of nitrogen deposition on fine-root production in forest ecosystems. New Phytologist. 147: 131-139.

Persson, H.; Majdi, H.; Clemensson-Lindell, A. 1995. Effects of acid deposition on tree roots. Ecological Bulletins. 44: 158-167.

Pregitzer, K.S.; Zak, D.R.; Maziasz, J.; DeForest, J.; Curtis, P.S.; Lussenhop, J. 2000. Interactive effects of atmospheric $\mathrm{CO}_{2}$ and soil-N availability of fine roots of populus tremuloides. Ecological Applications. 10: 18-33.

SAS Institute Inc. 2002. SAS User's Guide: Statistics. Version 9.1. SAS Institute Inc., Cary, NC.

Sherman, J.; Fernandez, I.J.; Norton, S.A.; Ohno, T.; Rustad, L.E. 2006. Soil aluminum, iron, and phosphorus dynamics in response to long-term experimental nitrogen and sulfur additions at the Bear Brook Watershed in Maine, USA. Environmental Monitoring and Assessment. 121: 421-429. 
Thompson, G.W.; Medve, R.J. 1984. Effects of aluminum and manganese on the growth of ectomycorrhizal fungi. Applied and Environmental Microbiology. 48: 556-560.

Tomlinson, G.H. 2003. Acid deposition, nutrient leaching and forest growth. Biogeochemistry. 65: 51-81.

Vogt, K.A.; Grier, C.C.; Vogt, D.J. 1986. Production, turnover, and nutrient dynamics of above- and belowground detritus of world forests. Advances in Ecological Research. 15: 303-377.

Wallenstein, M.D.; Peterjohn, W.T.; Schlesinger, W.H. 2006. N fertilization effects on denitrification and $\mathrm{N}$ cycling in an aggrading forest. Ecological Applications. 16: 21682176.

Yin, X.; Perry, J.A.; Dixon, R.K. 1989. Fine-root dynamics and biomass distribution in a Quercus ecosystem after harvest. Forest Ecology and Management. 27: 159-177. 


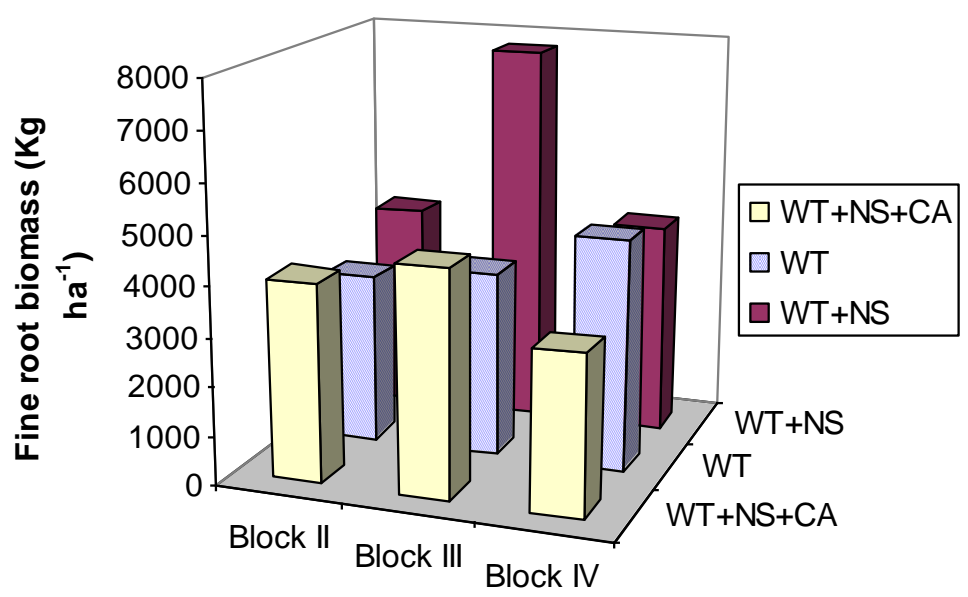

Figure 9. Fine root biomass $\left(\mathrm{kg} \mathrm{ha}^{-1}\right)$ by block and treatment. Treatments are unfertilized whole tree harvest (WT), whole tree harvest plus annual nitrogen and sulfur additions (WT+NS), and whole tree harvest plus nitrogen, sulfur, and dolomitic lime (WT+NS+CA).

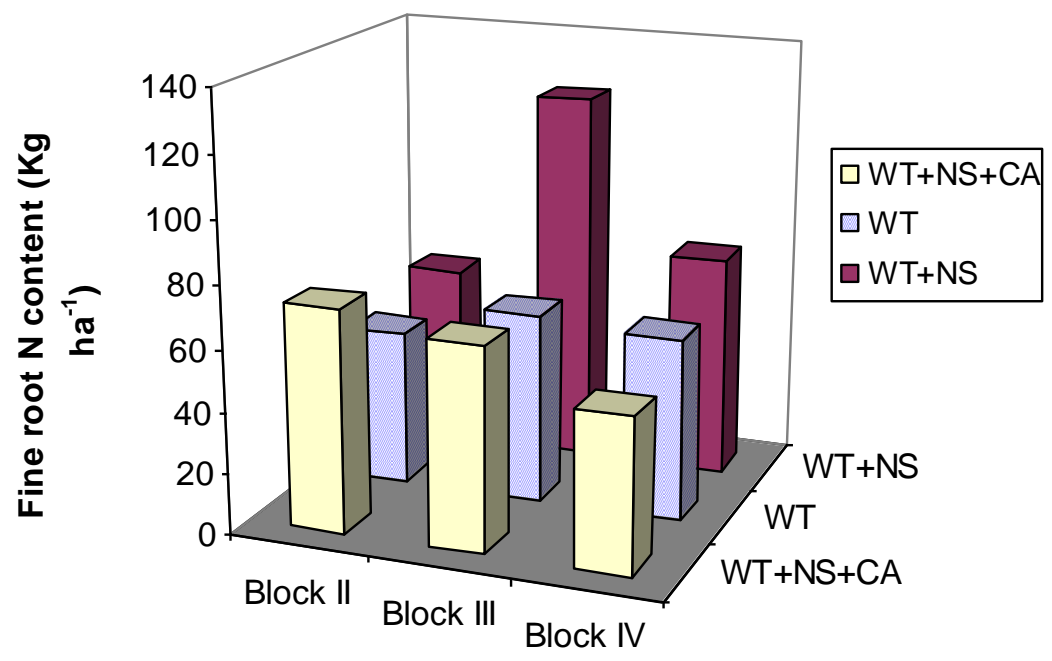

Figure 10. Fine root nitrogen content $\left(\mathrm{kg} \mathrm{ha}^{-1}\right)$ by block and treatment. Treatments are unfertilized whole tree harvest (WT), whole tree harvest plus annual nitrogen and sulfur additions (WT+NS), and whole tree harvest plus nitrogen, sulfur, and dolomitic lime (WT+NS+CA). 


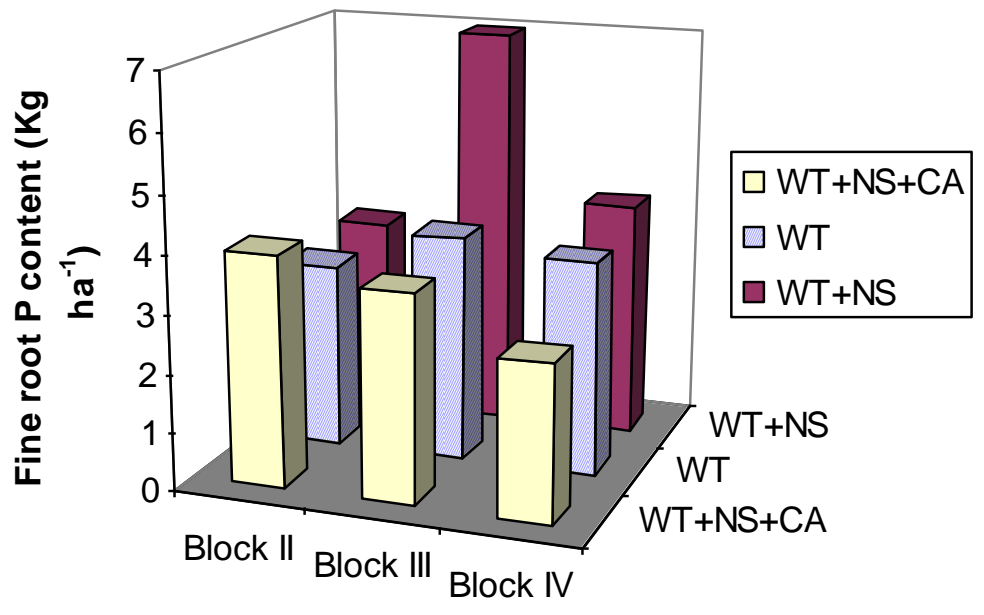

Figure 11. Fine root phosphorus content $\left(\mathrm{kg} \mathrm{ha}^{-1}\right)$ by block and treatment. Treatments are unfertilized whole tree harvest (WT), whole tree harvest plus annual nitrogen and sulfur additions (WT+NS), and whole tree harvest plus nitrogen, sulfur, and dolomitic lime (WT+NS+CA).

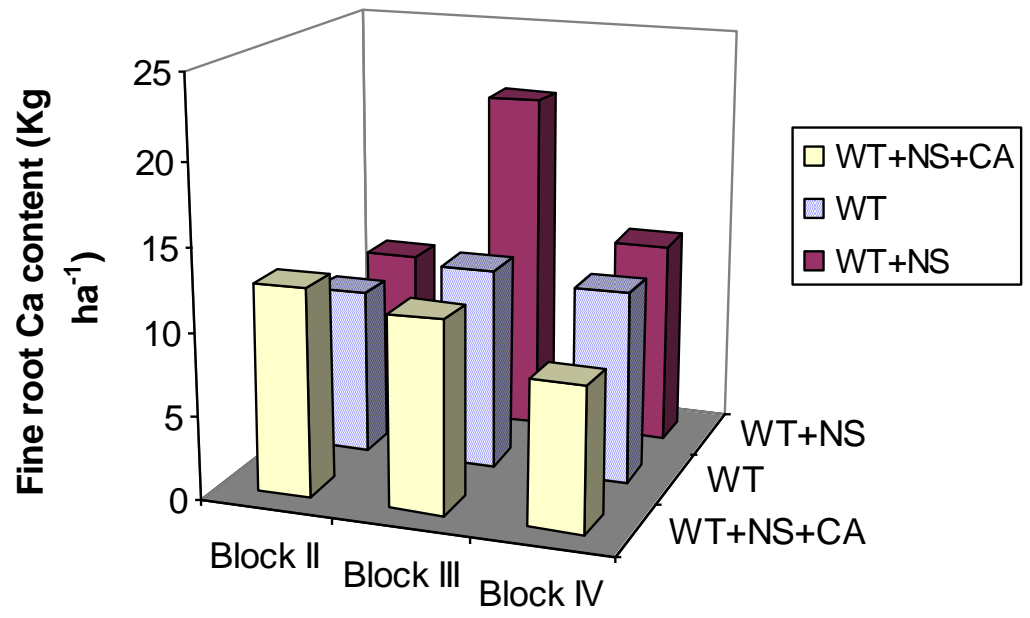

Figure 12. Fine root calcium content $\left(\mathrm{kg} \mathrm{ha}^{-1}\right)$ by block and treatment. Treatments are unfertilized whole tree harvest (WT), whole tree harvest plus annual nitrogen and sulfur additions (WT+NS), and whole tree harvest plus nitrogen, sulfur, and dolomitic lime (WT+NS+CA). 
Table 8. P-values for block, treatment, and block* treatment interactions for fine root biomass $\left(\mathrm{kg} \mathrm{ha}^{-1}\right)$, and fine root nutrient concentrations $(\%)$ and nutrient contents $\left(\mathrm{kg} \mathrm{ha}^{-1}\right)$. N/A denotes data not available.

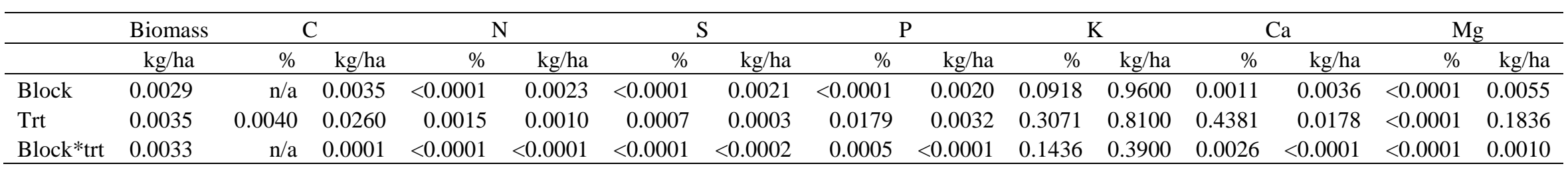

Table 9. Fine root macronutrient content values by treatment and block. Treatments are unfertilized whole tree harvest (WT), whole tree harvest plus annual nitrogen and sulfur additions (WT+NS), and whole tree harvest plus nitrogen, sulfur, and dolomitic lime (WT+NS+CA). Significant differences are indicated by different letters in the same column. All values are reported in $\mathrm{kg} \mathrm{ha}^{-1}$.

\begin{tabular}{|c|c|c|c|c|c|c|c|c|c|c|c|c|c|c|c|c|c|}
\hline Treatment & Block & Biomass & & $\mathrm{C}$ & & $\mathrm{N}$ & & $\mathrm{S}$ & & $\mathrm{P}$ & & $\mathrm{K}$ & & $\mathrm{Ca}$ & & $\mathrm{Mg}$ & \\
\hline WT & II & $3,441.5$ & $\mathrm{~b}$ & $1,290.6$ & $\mathrm{~b}$ & 50.6 & $\mathrm{~b}$ & 4.1 & $\mathrm{~b}$ & 3.2 & $\mathrm{~b}$ & 5.8 & $\mathrm{~b}$ & 10.0 & $\mathrm{~b}$ & 2.7 & \\
\hline $\mathrm{WT}+\mathrm{NS}$ & & $4,212.4$ & $\mathrm{~b}$ & $1,359.5$ & $\mathrm{~b}$ & 59.1 & $\mathrm{~b}$ & 4.9 & $\mathrm{~b}$ & 3.4 & $\mathrm{~b}$ & 6.0 & $\mathrm{~b}$ & 10.2 & $\mathrm{~b}$ & 2.6 & $\mathrm{~b}$ \\
\hline $\mathrm{WT}+\mathrm{NS}+\mathrm{CA}$ & & $4,035.4$ & & $1,830.0$ & & 72.1 & & 5.6 & & 4.0 & & 7.5 & & 12.6 & & 4.2 & \\
\hline WT & III & $3,766.0$ & & $1,579.6$ & & 61.9 & $\mathrm{~b}$ & 5.0 & $\mathrm{~b}$ & 3.9 & & 7.2 & & 12.2 & & 3.4 & \\
\hline $\mathrm{WT}+\mathrm{NS}$ & & $7,761.1$ & $\mathrm{a}$ & $2,801.7$ & $\mathrm{a}$ & 121.8 & $\mathrm{a}$ & 10.1 & $\mathrm{a}$ & 7.0 & $\mathrm{a}$ & 12.4 & $\mathrm{a}$ & 20.9 & $\mathrm{a}$ & 5.4 & $\mathrm{a}$ \\
\hline $\mathrm{WT}+\mathrm{NS}+\mathrm{CA}$ & & $4,592.9$ & & $1,681.6$ & & 66.2 & & 5.2 & $\mathrm{~b}$ & 3.6 & $\mathrm{~b}$ & 6.9 & & 11.6 & & 3.9 & \\
\hline WT & IV & $4,680.4$ & $\mathrm{~b}$ & $1,513.3$ & & 59.3 & $\mathrm{~b}$ & 4.8 & $\mathrm{~b}$ & 3.7 & $\mathrm{~b}$ & 6.9 & & 11.7 & & 3.2 & \\
\hline $\mathrm{WT}+\mathrm{NS}$ & & $4,300.9$ & & $1,658.1$ & & 72.1 & & 6.0 & & 4.1 & & 7.3 & & 12.4 & & 3.2 & \\
\hline $\mathrm{WT}+\mathrm{NS}+\mathrm{CA}$ & & $3,238.9$ & $\mathrm{~b}$ & $1,266.4$ & $\mathrm{~b}$ & 49.9 & $\mathrm{~b}$ & 3.9 & $\mathrm{~b}$ & 2.7 & $\mathrm{~b}$ & 5.2 & $\mathrm{~b}$ & 8.7 & $\mathrm{~b}$ & 2.9 & \\
\hline
\end{tabular}




\section{Chapter VI: Summary and Conclusions}

The results of this research indicate the importance of studying both above- and belowground components of forest biomass when searching for the effects of acidic atmospheric deposition. We tested the hypotheses that aboveground wood biomass and fine root biomass would be greater in the treated plots (WT+NS and $\mathrm{WT}+\mathrm{NS}+\mathrm{CA}$ ) compared to the control (WT). There were no significant differences in total aboveground wood biomass, while fine root biomass exhibited a significant block*treatment effect. The variety of responses seen in fine root biomass and therefore nutrient content between the treatments and blocks indicate differences in soil nutrient availability within these plots. For instance, the WT+NS treatment in block II did not see increased fine root biomass to the same extent as the WT+NS treatment in block III, which may be attributed to greater soil base cation availability in block II. The accentuated response of fine root biomass and nutrient content in the WT+NS treatment in block III is likely caused by the need to compensate for reductions of soil macronutrient availability caused by chronic acid deposition. Fine root N, P, and Ca concentration results did support the original hypotheses that $\mathrm{N}$ concentrations would be greater in the $\mathrm{WT}+\mathrm{NS}+\mathrm{CA}$ treatment in block III, that $\mathrm{P}$ concentrations would be greater in the WT+NS treatment in block II, and that Ca concentrations would be greater in the

WT treatment in block II. The acidification treatment has likely caused differences in soil chemistry by lowering $\mathrm{pH}$, to a different degree by block, which may have made $\mathrm{P}$ less available for plant uptake and increased the leachability of the cations $\mathrm{Ca}$ and $\mathrm{Mg}$ as suggested by lower allocation of $\mathrm{P}, \mathrm{Ca}$, and $\mathrm{Mg}$ concentrations to wood tissue in the 
$\mathrm{WT}+\mathrm{NS}$ treatment compared to the WT and WT+NS+CA treatments. Decreased Ca and $\mathrm{Mg}$ wood tissue concentrations in the WT+NS treatment compared to the WT treatment were hypothesized. Phosphorus and $\mathrm{N}$ were expected to have greater concentrations in wood in the treated plots (WT+NS and WT+NS+CA) compared to the control (WT); our results did not support that hypothesis. Even though this forest is young and nutrient resources belowground are probably not yet limiting, increased atmospheric deposition may affect aboveground wood and fine root biomass through lowered soil nutrient availability. Similarities in wood nutrient content between the WT and WT+NS+CA treatments indicate that additions of dolomitic lime have the potential to ameliorate the effects of acidic deposition in terms of aboveground wood chemistry. Alternatively, fine root biomass did not vary much between the WT and WT+NS+CA treatments, but this may be due to the high variation caused by block effects.

Biomass and nutrient $(\mathrm{C}, \mathrm{N}, \mathrm{P}, \mathrm{K}, \mathrm{Ca}$, and $\mathrm{Mg}$ ) budgets for fine roots, stem wood, and green foliage were developed to compare nutrient allocation among these vegetative components for the three treatments (Figures 13 to 19). A C budget was also created to estimate the effect of acidic deposition on biomass growth and $\mathrm{C}$ sequestration in a young hardwood forest. The values for green leaf tissue were derived from average biomass values for leaf litter estimates from Piatek et al. (2009) data and from green leaf nutrient concentrations from the Fernow Experimental Forest (Adams et al. 2004); these values did not include treatment effects. 
Averaged across the three treatments, aboveground wood biomass was $51,034 \mathrm{~kg} \mathrm{ha}^{-1}$, dry leaf litter mass was $1,928 \mathrm{~kg} \mathrm{ha}^{-1}$, and fine root biomass was 4,464 $\mathrm{kg} \mathrm{ha}^{-1}$ (Figure 13). Although not statistically significant, the WT+NS treatment had higher above- and belowground biomass compared to the WT and WT+NS+CA treatments, indicating its potential to be more productive and store more C (Figure 14). Therefore, implications of acidic deposition on $\mathrm{C}$ sequestration is important in this young forest, but the alterations in wood and fine root nutrient content and slightly increased fine root biomass in the $\mathrm{WT}+\mathrm{NS}$ treatment may be attributed to reduced nutrient availability in the soil. Greater storage of $\mathrm{N}$ in vegetative biomass is also important under higher inputs of $\mathrm{N}$ by acidic deposition because of the potential to diminish $\mathrm{N}$ leaching. Figure 15 indicates the ability of this young stand to retain $\mathrm{N}$ in the live vegetative pools in the WT+NS treatment, especially in fine roots.

All macronutrient content ratios in aboveground wood relative to fine roots were typically lowest in the WT+NS treatment owing to greater fine root biomass compared to the WT and WT+NS+CA treatments (Figures 13 to 19). Fine root nutrient content relative to green leaf nutrient content yielded higher ratios for all nutrients in the WT+NS treatment and was caused by higher fine root biomass as nutrient concentrations did not vary immensely between treatments. More fine root biomass compared to foliage for this forest was expected as a forest may use more energy for belowground compared to aboveground development at a young age. An unexpected pattern appeared when nutrient content in wood was compared to green leaf tissue, as allocation of nutrients to wood was highest in the WT+NS+CA treatment, but was only slightly greater than the WT+NS 
treatment for $\mathrm{P}, \mathrm{K}, \mathrm{Ca}$, and $\mathrm{Mg}$. Higher content of $\mathrm{Ca}$ and $\mathrm{Mg}$ in wood tissue in the $\mathrm{WT}+\mathrm{NS}+\mathrm{CA}$ treatment may be attributed to the dolomite amendments, which is utilized more in wood tissue than foliage for stem support and growth. The higher content of wood $\mathrm{P}$ and $\mathrm{K}$ in the $\mathrm{WT}+\mathrm{NS}+\mathrm{CA}$ treatment may be due to higher nutrient concentrations observed in wood compared to the other treatments. Because the WT+NS+CA and WT+NS treatments had similar leaf:wood nutrient ratios, both treatments seem to allow $\mathrm{P}, \mathrm{K}, \mathrm{Ca}$, and $\mathrm{Mg}$ to be more allocated to wood. These nutrient budgets therefore suggest that additions of ammonium sulfate alone or in combination with dolomite in this young forest have the potential to increase biomass production and nutrient content in aboveground wood and fine roots. These findings therefore suggest nutrient limitations exist in these stands.

Overall, this young forest has not realized major consequences caused by increased levels of acidic deposition. Productivity of belowground and aboveground biomass, therefore $\mathrm{C}$ sequestration, tended to be greater (though not significantly so) in the WT+NS treatment compared to the other treatments. Macronutrient utilization was also greater in the $\mathrm{WT}+\mathrm{NS}$ treatment due to greater biomass. Therefore at this time, twice ambient ammonium sulfate additions have improved this forest's productivity by potentially relieving $\mathrm{N}$ limitations; biomass responded to fertilization. However, in terms of vegetative nutrient concentration and content, chronic acidic deposition has influenced macro-nutrient relations between stem wood and fine roots, most notably for P. Phosphorus may be the subsequent limiting nutrient in the WT+NS treatment, especially with a decline in soil $\mathrm{pH}$ alongside increased $\mathrm{N}$ deposition; P-limitation has been 
indicated in other studies as well (Gress et al. 2007). As a result, P cycling may be tighter in vegetative biomass in the $\mathrm{WT}+\mathrm{NS}$ treatment.

Even though the WT+NS+CA treatment has lower wood and fine root biomass compared to the $\mathrm{WT}+\mathrm{NS}$ treatment, nutrient concentrations of $\mathrm{Ca}, \mathrm{Mg}, \mathrm{P}$, and $\mathrm{K}$ are greater in wood in the $\mathrm{WT}+\mathrm{NS}+\mathrm{CA}$ treatment, thereby resulting in a wood nutrient content in the dolomite treatment similar to the $\mathrm{WT}+\mathrm{NS}$ treatment. The improved nutritional status of wood (and possibly among other pools) with dolomitic lime amendments on acidic soils may result in heightened forest productivity in one or two more decades. SILVAH growth projections to 80 years of age also suggest a $34 \%$ potential increase in aboveground wood biomass in the $\mathrm{WT}+\mathrm{NS}+\mathrm{CA}$ treatment compared to WT and $\mathrm{WT}+\mathrm{NS}$ treatments. In time, the variation in biomass and nutrient content between treatments observed in this study will possibly become intensified as belowground nutrient competition increases. Therefore as this forest ages, comparisons between belowground and aboveground net productivity are imperative, as connections between these components need to be made to realize the impacts of acidic deposition on $\mathrm{C}$ sequestration and forest productivity as a whole. 


\subsection{Literature Cited}

Adams, M.B.; Burger, J.; Zelazny, L.; Baumgras, J. 2004. Description of the Fork Mountain long-term soil productivity study: site characterization. Gen. Tech. Rep. NE323. Newtown Square, PA: U.S. Department of Agriculture, Forest Service, Northeastern Research Station. 40 p.

Gress, S.E.; Nichols, T.D.; Northcraft, C.C.; Peterjohn, W.T. 2007. Nutrient limitation in soils exhibiting differing nitrogen availabilities: what lies beyond nitrogen saturation? Ecology. 88(1): 119-130.

Piatek, K.P.; Munasinghe, P.; Peterjohn, W.T.; Adams, M.B.; Cumming, J.R. 2009. Oak contribution to litter nutrient dynamics in an Appalachian forest receiving elevated $\mathrm{N}$ and dolomite. Canadian Journal of Forest Research: 39: 936-944. 

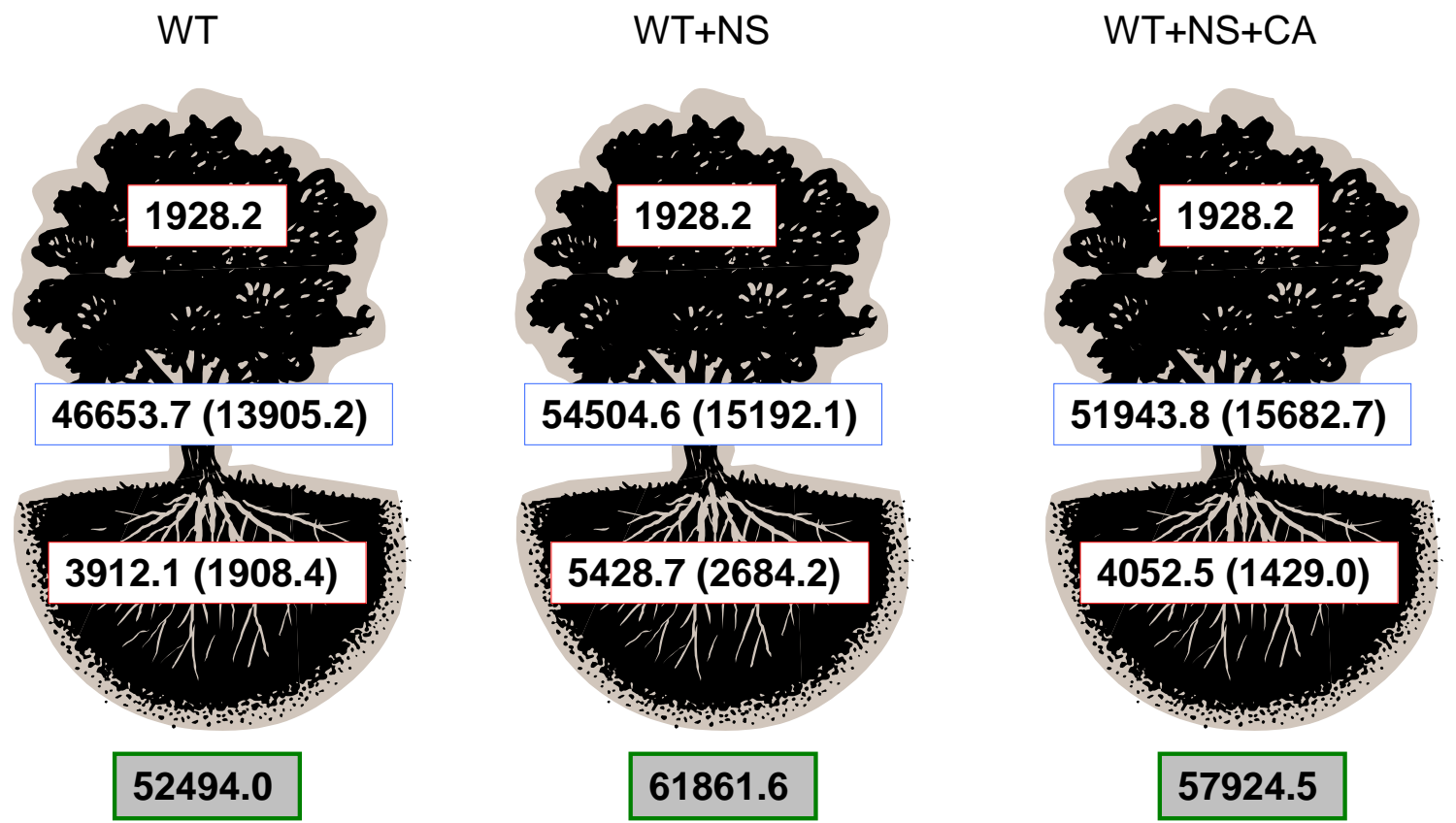

Figure 13. Foliage, aboveground wood, and fine root biomass $\left(\mathrm{kg} \mathrm{ha}^{-1}\right)$ in a ten-year-old forest at the Fernow Experimental Forest. Refer to Chapter 3 for wood biomass estimates and Chapter 5 for fine root biomass estimates; foliar biomass was estimated by Piatek et al. (2009). Standard deviations are in parentheses and biomass totals are in the grey boxes. 


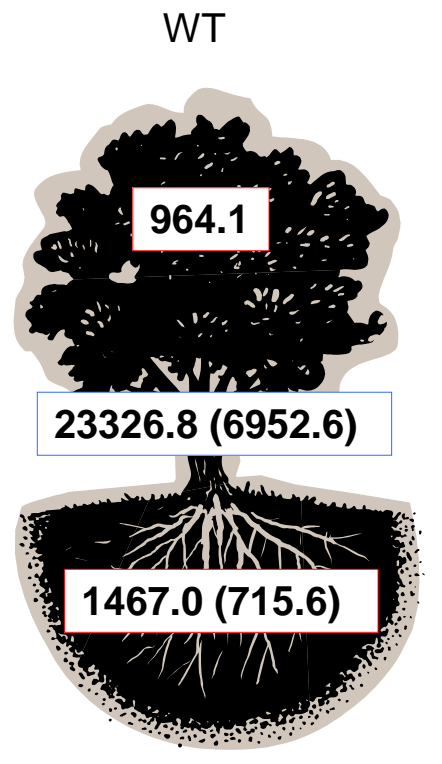

25757.9

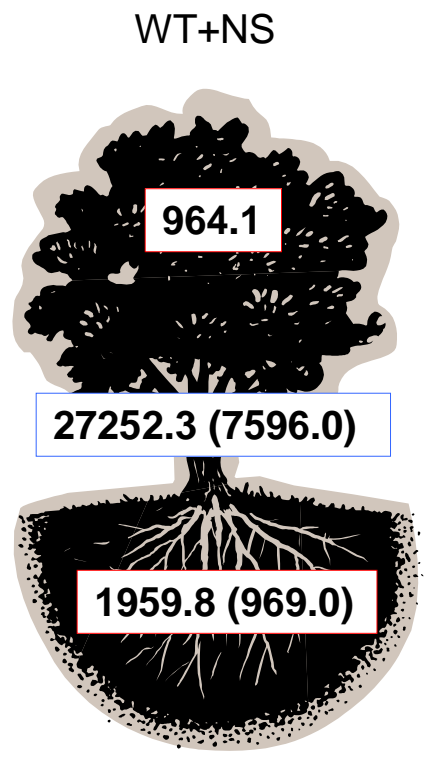

30176.2

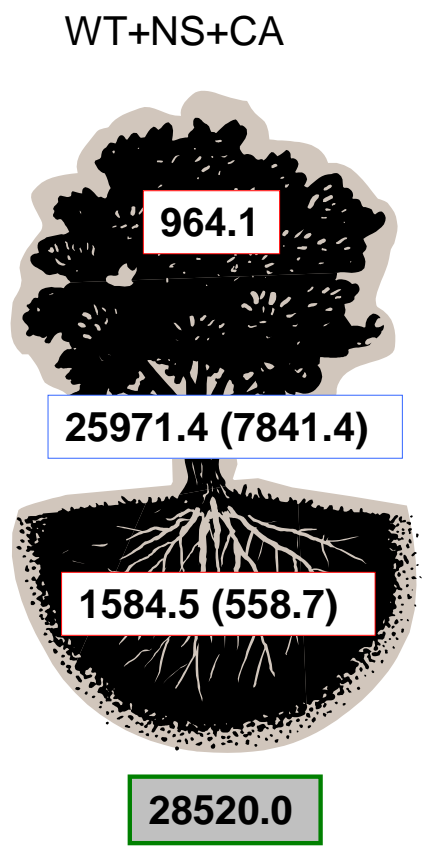

Figure 14. Foliage, aboveground wood, and fine root carbon content $\left(\mathrm{kg} \mathrm{ha}^{-1}\right)$ in a ten-year-old forest at the Fernow Experimental Forest. Refer to Chapter 3 for wood biomass estimates and Chapter 5 for fine root biomass and $\mathrm{C}$ estimates; foliar biomass was estimated by Piatek et al. (2009). Carbon content was calculated as $50 \%$ of wood and foliar biomass. Standard deviations are in parentheses and biomass totals are in the grey boxes. 

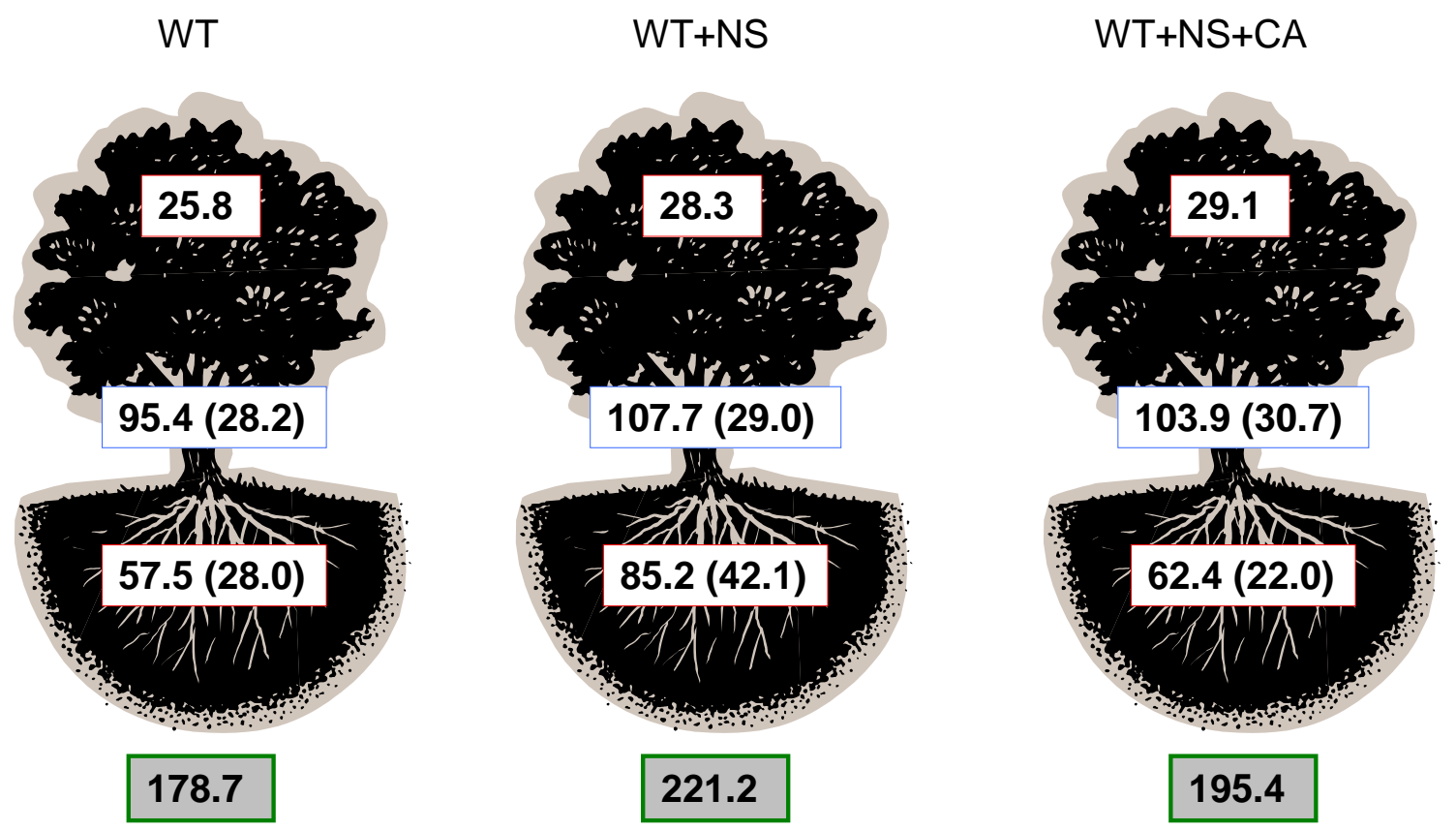

Figure 15. Foliage, aboveground wood, and fine root nitrogen content $\left(\mathrm{kg} \mathrm{ha}^{-1}\right)$ in a ten-year-old forest at the Fernow Experimental Forest. Refer to Chapter 3 for wood biomass and $\mathbf{N}$ estimates and Chapter 5 for fine root biomass and $\mathbf{N}$ estimates. Foliar biomass and $\mathbf{N}$ concentrations were estimated by Piatek et al. (2009). Standard deviations are in parentheses and biomass totals are in the grey boxes. 

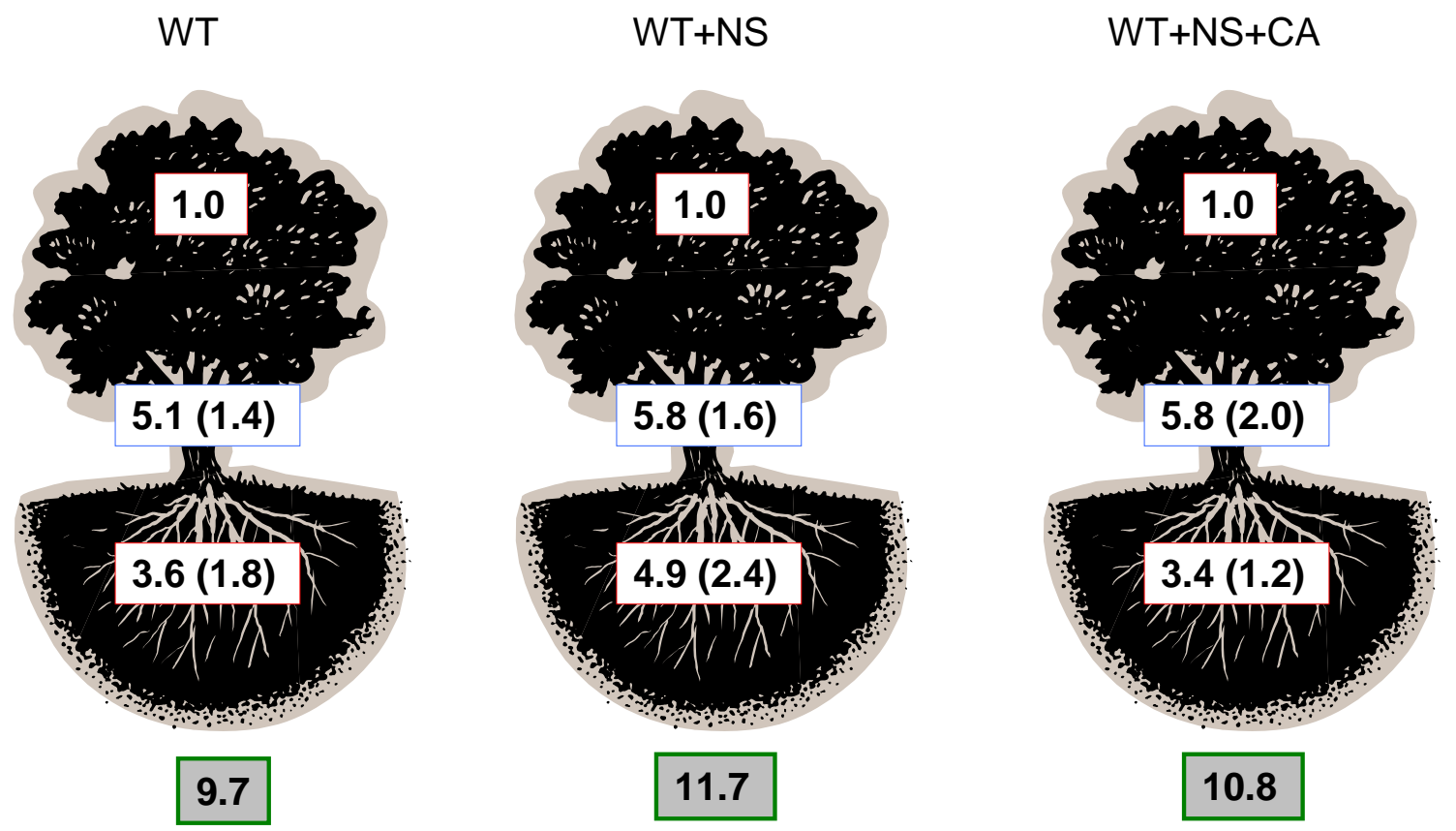

Figure 16. Foliage, aboveground wood, and fine root phosphorus content $\left(\mathrm{kg} \mathrm{ha}^{-1}\right)$ in a ten-year-old forest at the Fernow Experimental Forest. Refer to Chapter 3 for wood biomass and $P$ estimates and Chapter 5 for fine root biomass and $P$ estimates. Foliar biomass and $P$ concentrations were estimated by Piatek et al. (2009). Standard deviations are in parentheses and biomass totals are in the grey boxes. 


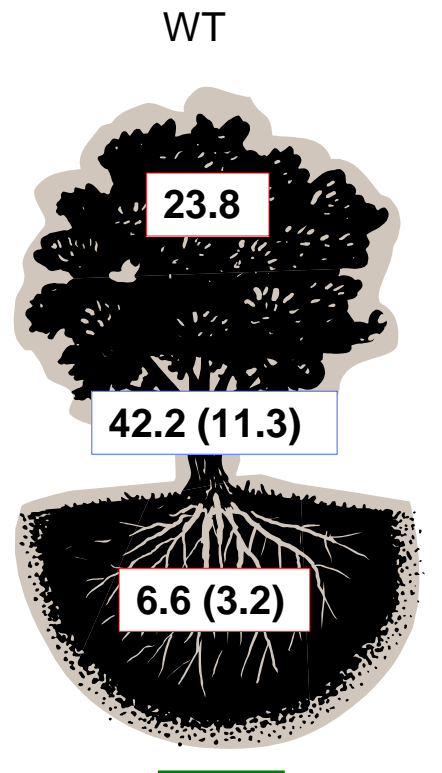

72.6
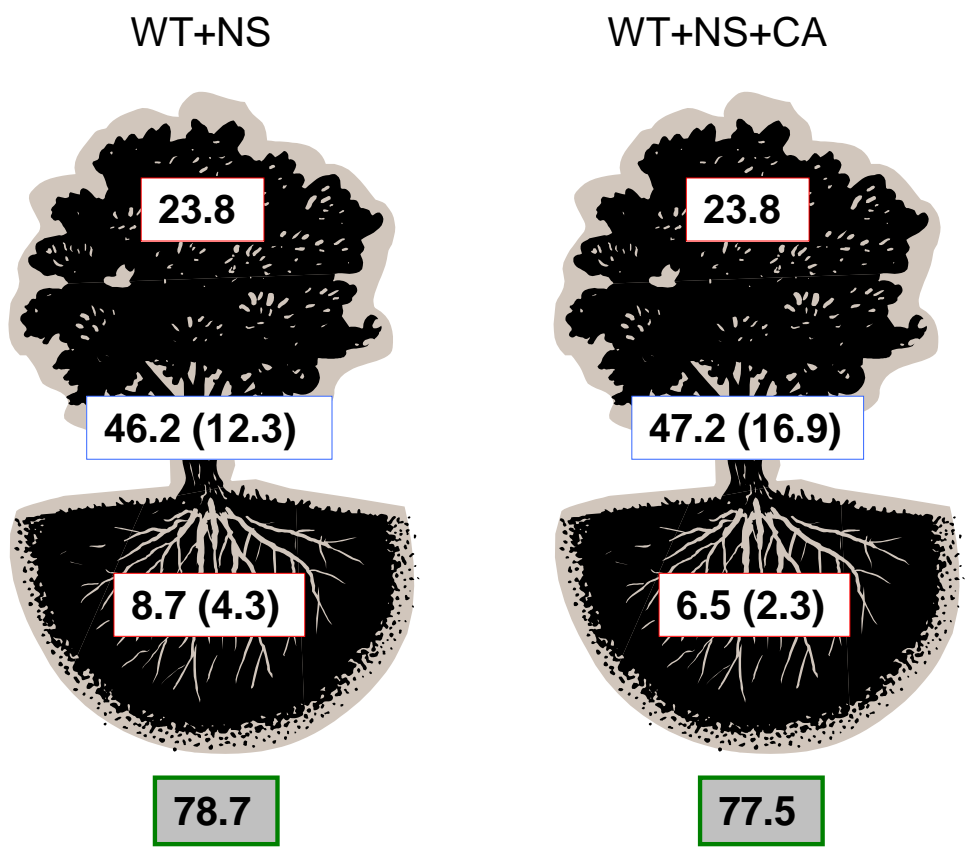

Figure 17. Foliage, aboveground wood, and fine root potassium content $\left(\mathrm{kg} \mathrm{ha}^{-1}\right)$ in a ten-year-old forest at the Fernow Experimental Forest. Refer to Chapter 3 for wood biomass and K estimates and Chapter 5 for fine root biomass and K estimates. Foliar biomass was estimated by Piatek et al. (2009) and foliar K concentrations were determined by Adams et al. (2004). Standard deviations are in parentheses and biomass totals are in the grey boxes. 

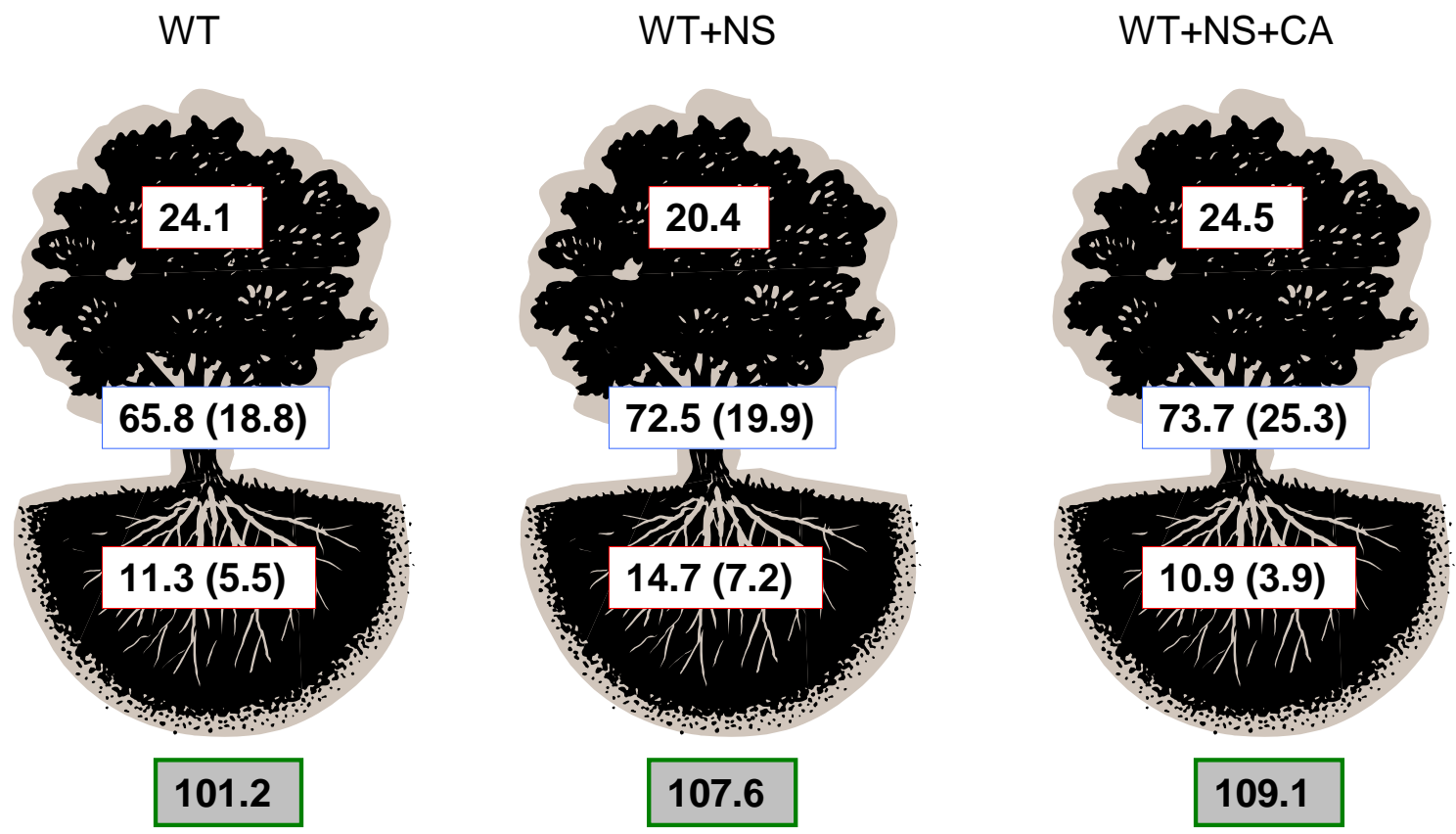

Figure 18. Foliage, aboveground wood, and fine root calcium content $\left(\mathrm{kg} \mathrm{ha}^{-1}\right)$ in a ten-year-old forest at the Fernow Experimental Forest. Refer to Chapter 3 for wood biomass and Ca estimates and Chapter 5 for fine root biomass and Ca estimates. Foliar biomass and Ca concentrations were estimated by Piatek et al. (2009). Standard deviations are in parentheses and biomass totals are in the grey boxes. 


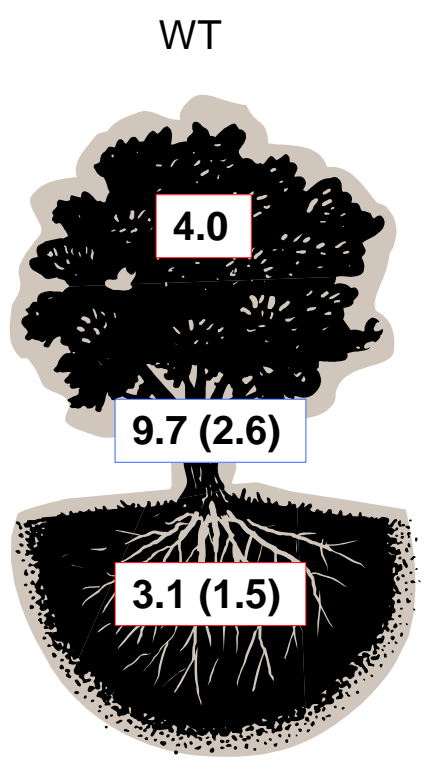

16.8

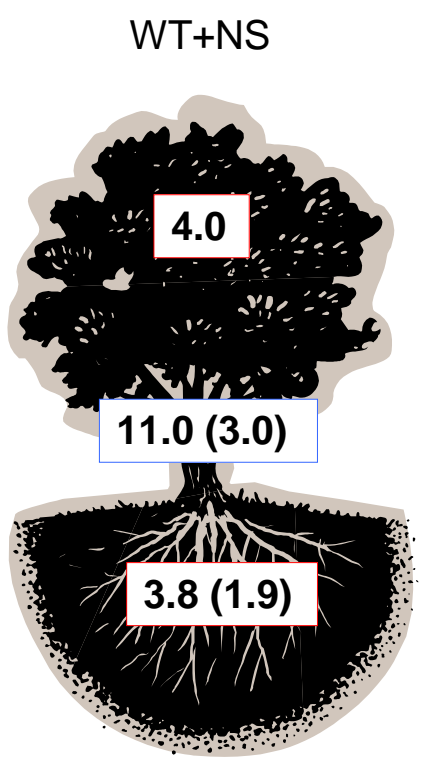

18.8

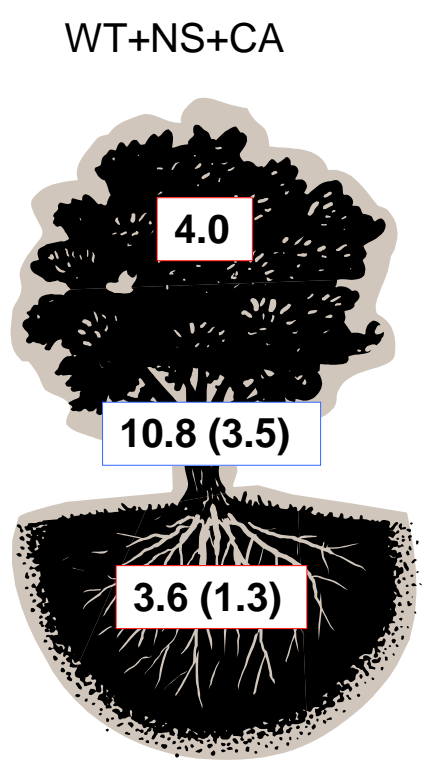

18.4

Figure 19. Foliage, aboveground wood, and fine root magnesium content $\left(\mathrm{kg} \mathrm{ha}^{-1}\right)$ in a ten-year-old forest at the Fernow Experimental Forest. Refer to Chapter 3 for wood biomass and Mg estimates and Chapter 5 for fine root biomass and Mg estimates. Foliar biomass was estimated by Piatek et al. (2009) and foliar Mg concentrations were determined by Adams et al. (2004). Standard deviations are in parentheses and biomass totals are in the grey boxes. 


\section{Appendix}

Table 10. List of common and scientific names of the tree species present on the Fernow Long-Term Soil Productivity site.

\begin{tabular}{ll}
\hline Common Species Name & Scientific Species Name \\
& \\
\hline Pin cherry & Prunus pensylvanica L.f. \\
Fraser magnolia & Magnolia fraseri Walt. \\
Yellow-poplar & Liriodendron tulipifera L. \\
Cucumbertree & Magnolia acuminata L. \\
Red maple & Acer rubrum L. \\
Black cherry & Prunus serotina Ehrh. \\
Sweet birch & Betula lenta L. \\
Striped maple & Acer pensylvanicum L. \\
E. hophornbeam & Ostrya virginiana (Mill.) K. Koch \\
Yellow birch & Betula alleghaniensis Britton \\
Sassafras & Sassafras albidum (Nutt.) Nees \\
White ash & Fraxinus americana L. \\
Sugar maple & Acer saccharum Marsh. \\
Black locust & Robinia pseudoacacia L. \\
Northern red oak & Quercus rubra L. \\
Sourwood & Oxydendrum arboreum (L.) DC. \\
\hline
\end{tabular}

